\author{
UNIVERSIDADE DE SÃO PAULO \\ FACULDADE DE ECONOMIA, ADMINISTRAÇÃO E CONTABILIDADE \\ PROGRAMA DE PÓS-GRADUAÇÃO EM ECONOMIA
}

\title{
Uma investigação sobre a autonomia de política monetária em países emergentes
}

Rodrigo Toneto

Orientadora: Laura Barbosa de Carvalho

São Paulo, Brasil

2020 
Prof. Dr. Vahan Agopyan

Reitor da Universidade de São Paulo

Prof. Dr. Fábio Frezatti

Diretor da Faculdade de Economia, Administração e Contabilidade (FEA/USP)

Prof. Dr. Jose Carlos de Souza Santos

Chefe do Departamento de Economia

Prof. Dr. Ariaster Baumgratz Chimeli

Coordenador do Programa de Pós-Graduação em Economia 
RODRIGO TONETO

\title{
Uma investigação sobre a autonomia de política monetária em países emergentes
}

Dissertação apresentada ao Departamento de Economia da Faculdade de Economia, Administração e Contabilidade da Universidade de São Paulo como requisito parcial para a obtenção do título de Mestre em Ciências.

Orientadora: Laura Barbosa de Carvalho

\author{
Versão Corrigida \\ (Versão original disponível na Biblioteca da Faculdade de Economia, \\ Administração e Contabilidade)
}

São Paulo, Brasil 
Catalogação na Publicação (CIP)

Ficha Catalográfica com dados inseridos pelo autor

Toneto, Rodrigo.

Uma investigação sobre a autonomia de política monetária em países emergentes / Rodrigo Toneto. - São Paulo, 2020.

$88 \mathrm{p}$.

Dissertação (Mestrado) - Universidade de São Paulo, 2020.

Orientador: Laura Barbosa de Carvalho.

1. Autonomia de Política Monetária. 2. Finanças Internacionais. 3. Economia Monetária. I. Universidade de São Paulo. Faculdade de Economia, Administração e Contabilidade. II. Título. 
Rodrigo Toneto

\section{Uma investigação sobre a autonomia de política monetária em países emergentes}

Dissertação apresentada ao Departamento de Economia da Faculdade de Economia, Administração e Contabilidade da Universidade de São Paulo como requisito parcial para a obtenção do título de Mestre em Ciências.

Laura Barbosa de Carvalho

Orientador

Professor Dr. Eduardo Zilberman

Professor Dr. Frederico Gonzaga

Jayme Júnior

Professor Dr. Márcio Issao Nakane

São Paulo, Brasil

2020 


\section{Agradecimentos}

Aprendi no movimento estudantil que não há saídas individuais para problemas coletivos. Embora escrever uma dissertação seja uma tarefa absolutamente solitária, este trabalho é fruto de reflexões compartilhadas às quais eu sou muito grato. A lembrança de todas e todos aqueles que junto de mim construíram esta pesquisa possibilitou momentos de alegria em meio a uma pandemia tão catastrófica.

O presente trabalho foi realizado com apoio da Coordenação de Aperfeiçoamento de Pessoal de Nível Superior - Brasil (CAPES) - Código de Financiamento 001. Este trabalho também foi realizado com apoio da Fundação Instituto de Pesquisas Econômicas (Fipe). Agradeço particularmente ao Prof. Carlos Luque e à Ana Ferri por todo o suporte da fundação.

Esta dissertação é devedora de todos os trabalhadores e trabalhadoras da FEA, funcionários da USP ou terceirizados, em seus esforços para garantir a existência da escola. Agradeço particularmente à Alda Castro, à Margarida, ao Marcos, à Milena,ao Ivan, ao Evandro, à Valéria, à Dona Lígia pela paciência, aprendizado e apoio ao longo de toda minha trajetória na Escola. Todos os dias milhares de estudantes aproveitam da imensa infraestrutura universitária, na figura da equipe do restaurante central agradeço a todos os servidores da universidade.

O Prof. Ariaster Chimeli e o Prof. José Carlos estiveram, respectivamente, à frente da coordenação da pós e da chefia do departamento ao longo dos meus anos de mestrado e, mesmo diante da aridez da tarefa, sempre receberam os alunos de maneira acolhedora e atenciosa. Tive a oportunidade ser monitor de disciplinas de graduação e pós-graduação ao longo dos últimos anos, a experiência foi muito proveitosa graças à paciência e à sabedoria da Fabiana Rocha, Gabriel Madeira, David Turchick e Maria Cristina Cacciamali. Agredeço ao Porf. Marcos Nakaguma pelo aprendizado em sala de aula e em especial por sugestões de leitura que ajudaram a formatar esta pesquisa. Em memória do Prof. Raul Cristóvão, agradeço às demais professoras e professores do departamento. Ao Amaury Gremaud, Paulo Furquim e Roberto Vermulm agradeço por me mostrarem que em meio às ingratidões econômicas há espaço para o samba. À Leda Paulani, exemplo de professora e economista, obrigado por me fazer acreditar que um mundo melhor é possível e necessário.

Nas oportunidades que tive de apresentar este trabalho, sempre recebi críticas e sugestões importantes para o amadurecimento do trabalho e meu próprio. Agredeço à Daniela Prates, ao Eduardo Zilberman, ao Frederico Jayme Jr, ao Márcio Nakane e ao José Francisco Lima, os dois últimos além de banca foram professores fundamentais em minha formação acadêmica. 
Os anos de mestrado seriam impossíveis sem a amizade da minha turma. agradeço pelas horas de truco, cerveja e estudo. A pesquisa me propiciou a convivência em um ambiente criativo, exigente e dinâmico que hoje se intitula MADE - Grupo de Pesquisa em Macroeconomia das Desigualdades. Sou grato à Clara Brenck e ao Pedro Marques pela parceria acadêmica e sobretudo pela amizade e pelo companheirismo. Ao Gilberto Lima, agradeço pela enorme dedicação com todos nós, por seu rigor e por sua generosidade dos quais pude me beneficiar dentro e fora da sala de aula. Ao Fernando Rugitsky, agradeço por me instigar criatividade e pensamento crítico e pelo companheirismo em tantas batalhas. A minha orientadora, Laura Carvalho, inspira uma geração de jovens economistas, comigo não é diferente. Em toda reunião ou conversa que tivemos sempre aprendi muito com sua disposição a debater novas ideias, sua sensibilidade econômica e seu engajamento na transformação do país. O fim desta dissertação marca também o encerramento de um período de oito anos em que a FEA e a USP foram a minha verdadeira casa. Sou grato por ter tido uma vivência universitária ampla. Ao André Singer e à Nilce Aravecchia agradeço por terem me mostrado a importância de se atravessar a Luciano Gualberto e de se viver a universidade de maneira coletiva.

Aprendi desde cedo que sem objetivo as paixões perdem o ímpeto. Foi na luta por um Brasil mais democrático e justo que encontrei pessoas como a Beatrice Weber, Bárbara Martins, Cassiana Ferreira, Daniel Freitas, Egle Lippi, Isabela Benassi, Júlia Kopf, Maria Alice Vieira, Mauro Cruzeiro, Rafael Valente, Vivian Mendes, Vitor Quarenta e Ynaê Lolito, com quem dividi angústias, vitórias e, acima de tudo, esperança. Ao Daniel Zylbersztajn e à Nicole Herscovici, agradeço pelo afeto e companheirismo diante das incertezas da vida. Ao Giuseppe Falco agradeço por ser, há 23 anos, companheiro, amigo e parceiro intelectual. Nenhuma alegria vivida na FEA se equipara a felicidade de ter encontrado bons amigos. Em nome do Ives Fernandes, Guilherme Ribeiro, Henrique Plens, Pedro Picchetti e Thaís Haddad saúdo às grandes amizades desde o tempo de CAVC e Vivência. Ao Gabriel Jardanovski, Lucas Câmara, Victor Vaccaro e Vinícius Fernandes agradeço por não saber mais dizer o quanto de mim veio de vocês. Ao Luís Alvarez agradeço pela amizade e generosidade ao longo de todos estes anos. Sem a parceria do Matias Cardomingo durante as diversas aventuras nas quais nos colocamos, este trabalho não teria sido possível e eu certamente seria um economista mais solitário.

Ao Alexandre Pupo agradeço com o coração por em tempos de desamor ter me dado a coragem necessária para ser feliz. A inteligência e a lealdade da Lígia Toneto, minha melhor amiga e irmã, fazem do cotidiano algo extraordinário e transformam a tristeza em risadas. Ao meu pai, Rudinei Toneto, agradeço por ter me ensinado a ver o mundo com os olhos de quem quer transformá-lo, sempre transbordando bondade e determinação. À minha mãe, Diana Junkes, sou grato pelo carinho que lhe sobra e por sempre colocar rimas em versos em branco, abrindo as portas escondidas aos céticos. 
É um assunto muito difícil para esquerda e muito fácil para a direita. A esquerda fica tentando te explicar, não, porque é preciso deixar entrar aqui o cara não sei das contas, tal. A direita é a direta, não vai entrar porque nós queremos empregos para os italianos, para os suíços, porque nós queremos emprego. Então, marginaliza o coitado do pobre enquanto o capital não tem nem passaporte, o capital é livre para transitar os atlânticos, os espaços aéreos sem ninguém pedir licença.

Presidente Lula em entrevista à Folha, março/2020

E tudo que é de ruim sempre cai pra cá. 


\section{Resumo}

A capacidade de economias domésticas de acomodarem choque externos motiva extenso debate na literatura econômica. O discurso convencional atribuí ao câmbio flutuante o papel de assegurar a autonomia da política monetária em face da mobilidade de capitais, especialmente após a consolidação do arcabouço de Mundell-Fleming. A ciclicidade dos fluxos de capitais e o caráter potencialmente contracionista de uma desvalorização cambial - seja por conta de seu impacto inflacionário ou por meio de efeitos financeiros nos balanços das firmas - motivaram, recentemente, esforços empíricos e teóricos para compreender em que medida os resultados do modelo canônico se sustentam, particularmente em economias emergentes. A partir de uma reconstrução histórica do conceito, define-se autonomia de política monetária como a capacidade de determinada economia em minimizar a volatilidade de variáveis domésticas diante de choques externos. Em um modelo agregado para uma pequena economia aberta, evidencia-se que o ciclo financeiro global, o repasse cambial para inflação e a existência de transbordamentos financeiros diminuem a capacidade do câmbio flutuante de absorver mudanças externas.Posteriormente, essa análise é aprofundada utilizando um modelo Novo Keynesiano para uma economia aberta com setor financeiro. Mostra-se que diante da não internalização por meio dos agentes financeiros das externalidades associadas ao risco cambial do financiamento externo, a adoção de políticas macroprudenciais aumentam a independência da autoridade monetária. Adicionalmente, por conta do repasse cambial significativo decorrente de choques externos, uma maior leniência com a inflação eleva a efetividade da política monetária doméstica.

Palavras-chave: Política Monetária, Finanças Internacionais, Economias Emergentes 


\section{Abstract}

The ability of domestic economies to accommodate external shocks instigates extensive debate in the economic literature. Conventional wisdom attributed to the floating exchange rate the capacity of ensuring monetary policy autonomy when capital mobility is assured, especially after the widespread adoption of the Mundell-Fleming framework. The cyclical behavior of capital flows and the potentially contractionary nature of currency devaluations - either because of its inflationary impact or its financial effects on firms' balance sheets - have recently motivated empirical and theoretical efforts to verify to which extent the canonical results hold, particularly in emerging economies. Grounded on a historical perspective, we define monetary policy autonomy as the capacity of a given economy to minimize domestic variables' volatility when facing foreign shocks. In an aggregated model for a small open economy, we show that the global financial cycle, the exchange rate pass-through to inflation, and the existence of financial spillovers diminish the floating exchange rate ability to insulate domestic economies. To further expand this analysis, we develop a New Keynesian model for an open economy with a financial sector. Once bankers do not incorporate the aggregate risk of exchange rate fluctuation in their leverage and indebtedness decisions, macroprudential policies widen policy autonomy. Additionally, because of the significant exchange rate pass trough that worsen the monetary policy trade-offs, greater leniency with inflation would enhance better accommodation of external shocks.

Key-words: Monetary Policy, International Finance, Emerging Markets 


\section{Sumário}

Introdução $\ldots \ldots \ldots \ldots \ldots \ldots \ldots \ldots \ldots$

1 A QUESTÃO DA AUTONOMIA DE POLÍTICA MONETÁRIA EM PAÍSES EMERGENTES . . . . . . . . . . . . . 6

1.1 Por que autonomia de política monetária? . . . . . . . . 6

$1.2 \quad$ Por que em países emergentes? . . . . . . . . . . . . . 7

1.3 Uma (breve) perspectiva histórica da questão da autonomia de política monetária . . . . . . . . . . . . . . . . . . . 9

1.3.1 Da controvérsia bullionista ao arcabouço de Mundell-Fleming . . . . . . . 9

1.3.2 O arcabouço de Mundell-Fleming . . . . . . . . . . . . . . 10

1.3.3 A construção de um novo paradigma da política econômica . . . . . . . . . 11

1.3.4 Autonomia de política monetária: "what have we learned?" . . . . . . . . 14

1.4 Uma possível definição para a autonomia de política monetária . . . 16

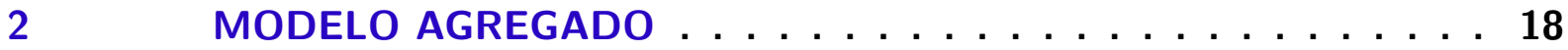

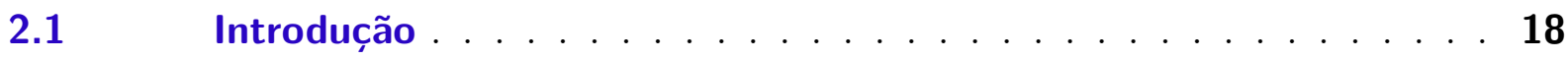

$2.2 \quad$ O Modelo Agregado . . . . . . . . . . . . . . . . . . . . 19

2.2 .1 Solução do modelo . . . . . . . . . . . . . . . . . . . 21

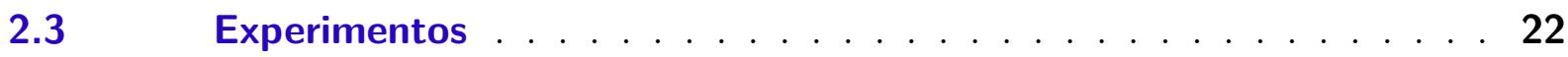

$2.3 .1 \quad$ Controle de Capitais . . . . . . . . . . . . . . . . . . 26

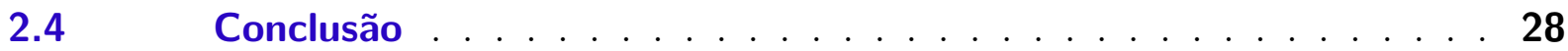

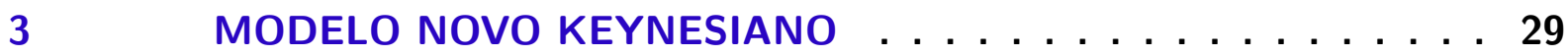

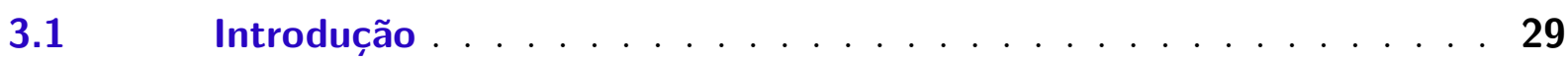

$3.2 \quad$ O Modelo Novo Keynesiano . . . . . . . . . . . . . . . . . 30

$3.2 .1 \quad$ Firmas . . . . . . . . . . . . . . . . . . . . 30

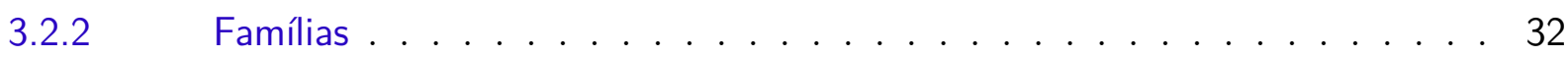

$3.2 .3 \quad$ Bancos . . . . . . . . . . . . . . . . . . . 34

3.2.4 Setor Externo e Variáveis Exógenas . . . . . . . . . . . . . . . . . . . 39

3.2.5 Equilíbrio de Mercado . . . . . . . . . . . . . . . . . . . . . . 39

3.3 Experimentos e Análise dos Resultados . . . . . . . . . . . . . 40

3.3.1 Modelo Base . . . . . . . . . . . . . . . . . . . . . . . . . . 45

3.3.2 Ciclo Financeiro Global . . . . . . . . . . . . . . . . . . 47

$3.3 .3 \quad$ Inflação . . . . . . . . . . . . . . . . . . . . 50

3.3.4 Controle de Capital e Medidas Macroprudenciais . . . . . . . . . . . . . 53

3.4 Medindo a Autonomia da Política Monetária . . . . . . . . . . . . 62 
3.4.1 Capacidade de absorção do choque externo . . . . . . . . . . . . 62

3.4.2 Minimização da função perda: choques externos . . . . . . . . . . . . . . . 64

3.4.3 Minimização da função perda: caso geral . . . . . . . . . . . . . . 65

$3.5 \quad$ Conclusão . . . . . . . . . . . . . . . . . . . . . 66

Considerações Finais . . . . . . . . . . . . . . . . . . . . . 68

REFERÊNCIAS ..................... 70

$\begin{array}{ll}\text { APÊNDICES } & 76\end{array}$

APÊNDICE A - EQUIVALÊNCIA ENTRE MODELO AGREGADO NOMINAL E REAL . . . . . . . . . . . . 77

APÊNDICE B - OTIMIZAÇÃO DA AUTORIDADE MONETÁRIA DO MODELO AGREGADO . . . . . . . . 78

APÊNDICE C - EQUILÍBRIO COMPETITIVO . . . . . . . . 79

APÊNDICE D - ESTADO ESTACIONÁRIO NÃO-ESTOCÁSTICO 82

APÊNDICE E - ANÁLISE DE BEM-ESTAR . . . . . . . . . 85

APÊNDICE F - CHOQUES DOMÉSTICOS . . . . . . . . . 87 


\section{Lista de ilustrações}

Figura 1 - Modelo Base: Choque de 1\% Taxa de Juros Externa . . . . . . . . . . 23

Figura 2 - Comparação $f=0 \times f=0.3$ : Choque de 1\% Taxa de Juros Externa . . 24

Figura 3 - Comparação $f=0.3 \times f=0.6$ : Choque de $1 \%$ Taxa de Juros Externa . 25

Figura 4 - Comparação $g=0 \times g=0.3$ : Choque de 1\% Taxa de Juros Externa . . 26

Figura 5 - Comparação $\omega_{\text {tau }}=0 \mathrm{x} \omega_{\text {tau }}=0.1$ : Choque de $1 \%$ Taxa de Juros Externa 27

Figura 6 - Esquema ilustrativo do Modelo Novo Keynesiano . . . . . . . . . . . 30

Figura 7 - Propagação do Choque: impacto nas variáveis externas . . . . . . . . . 43

Figura 8 - Propagação do choque: impacto na balança comercial . . . . . . . . . . 44

Figura 9 - Propagação do choque: impacto nas Firmas . . . . . . . . . . . . . 44

Figura 10 - Propagação do Choque: impacto no setor financeiro . . . . . . . . . . . 45

Figura 11 - Modelo Base: Choque de + 1\% Taxa de Juros Externa (anual) . . . . . 46

Figura 12 - Modelo Base: Choque de - 1\% na demanda global . . . . . . . . . . 48

Figura 13 - Modelo Base: Choque de $1 \%$ no prêmio de risco . . . . . . . . . . . . 49

Figura 14 - Ciclo Financeiro Global: Choque de - 1\% na taxa de juros l . . . . . 51

Figura 15 - Ciclo Financeiro Global: Choque de - 1\% na demanda global . . . . . 52

Figura 16 - Rigidez de preços: Choque de $1 \%$ na taxa de juros externa . . . . . . . 53

Figura 17 - Rigidez de preços: Choque de - 1\% na demanda global . . . . . . . . 54

Figura 18 - Menor aversão à inflação: Choque de $1 \%$ na taxa de juros externa . . . 55

Figura 19 - "Duplo mandato": Choque de - 1\% na demanda global . . . . . . . . 56

Figura 20 - Controle de Capital $\left(K^{b}\right)$ : Choque de $1 \%$ na taxa de juros externa . . . 57

Figura 21 - Requisito de Capital $\left(D^{*}\right)$ : Choque de $1 \%$ na taxa de juros externa . . 59

Figura 22 - Medidas Combinadas: Choque de 1\% na taxa de juros externa . . . . . 60

Figura 23 - Medidas Combinadas: Choque de - 1\% na demanda global . . . . . . . 61

Figura 24 - Problema do banco em relação à $x_{t} \ldots \ldots$. . . . . . . . . . . 80

Figura 25 - Modelo Base: Choque de $+1 \%$ na produtividade . . . . . . . . . 87

Figura 26 - Modelo Base: Choque de $+1 \%$ no juro nominal doméstico (anual) . . . 88 


\section{Lista de tabelas}

Tabela 1 - Efeito de controles de capital para diferentes níveis de financial spillovers 28

Tabela 2 - Parâmetros do Cenário Base . . . . . . . . . . . . . . . 41

Tabela 3 - Valores de Estado Estacionário (Anuais) . . . . . . . . . . . . . 42

Tabela 4 - Absorção a um choque de $1 \%$ na taxa anual de juros externa: renda líquida .......................... 63

Tabela 5 - Absorção a um choque de 1\% na taxa anual de juros externa: inflação . 63

Tabela 6 - Absorção a um choque de 1\% na taxa anual de juros externa: diferentes parâmetros da autoridade monetária . . . . . . . . . . . 63

Tabela 7 - Autonomia da autoridade monetária: choques externos . . . . . . . 65

Tabela 8 - Autonomia da autoridade monetária: caso geral . . . . . . . . . 66 


\section{Introdução}

As autoridades monetárias dos diversos países são confrontadas com a necessidade de escolher políticas macroeconômicas que combinam objetivos e instrumentos alternativos. As opções abrangem diferentes regimes cambiais, distintos níveis de integração financeira, formas variadas de lidar com a inflação, objetivos múltiplos e por vezes conflitantes. A inserção internacional das economias faz com que escolhas de políticas domésticas tenham que levar em conta o cenário externo.

A existência de uma única moeda doméstica, o dólar, que denomina a maioria das reservas internacionais e que é majoritária nas transações financeiras e comerciais faz com que as condições monetárias globais sejam dependentes da política monetária dos EUA (GOURINCHAS; REY; SAUZET, 2019). Desse modo, uma questão central que se impõe às autoridades monetárias dos países periféricos é de que maneira reagir a alterações da política econômica do centro. As condições que determinado país possui de acomodar um choque externo definem o grau de autonomia, ou independência, de sua política monetária.

A existência de transbordamentos entre as economias nacionais motivou ao longo da segunda metade do século passado uma literatura extensa sobre coordenação internacional (Hamada (1976); Sachs (1983); Rogoff (1992)). Estes e outros artigos debatiam os ganhos potenciais de uma maior coordenação entre os países na determinação de sua política monetária e, principalmente, a dificuldade que seria estabelecer este equilíbrio, pois, como argumentam, haveria desvios lucrativos.

De acordo com o arcabouço de Mundell-Fleming, as autoridades monetárias dos diversos países, caso optem por garantir uma integração financeira com o resto do mundo, só possuiriam autonomia para perseguir objetivos domésticos com a política monetária caso adotassem o regime de câmbio flutuante. A este fenômeno, Obstfeld e Taylor (1998) deram o nome de Trilema da política monetária. Isto é, diante de um choque externo a autonomia da política monetária estaria assegurada pela assimilação do choque via flutuação do câmbio. Ao permitir que a acomodação de um choque contracionista (expansionista) da política monetária do centro se dê por meio da depreciação (apreciação) cambial, a autoridade monetária doméstica é capaz de garantir o retorno da economia ao equilíbrio anterior ao choque. A possibilidade de insular as economias locais de eventos estrangeiros por meio da variação cambial fez com que o debate sobre coordenação internacional ficasse em segundo plano a partir dos anos 1990 (FRANKEL, 2016).

As mudanças na economia internacional após a Crise Financeira Global de 2008 e novas discussões teóricas que emergiram neste período reativaram discussões sobre a efetividade do regime cambial em garantir autonomia da política monetária e a necessidade 
de se pensar estratégias alternativas tanto intra como extranacionais. A declaração, em 2011, do então Ministro da Fazenda do Brasil, Guido Mantega, de que o país enfrentava uma guerra cambial se tornou evidência anedótica das dificuldades enfrentadas por economias periféricas diante do afrouxamento quantitativo promovido pelo Federal Reserve Bank (FED). Anos mais tarde, em 2014, com a reversão da política expansionista do banco central estadunidense, foi Raghuram Rajan, presidente do Banco Central da Índia, que verbalizou o descontentamento dos emergentes ao dizer que os EUA deveriam se preocupar com os impactos que suas decisões de política monetária têm nos demais países (BLANCHARD, 2016).

Durante o período de política monetária mais frouxa e de intensificação dos fluxos de capitais para os países emergentes, uma variedade de políticas foi adotada para frear o boom de crédito. A partir de 2009, o Brasil, por exemplo, adotou taxas sobre fluxos de curto prazo (portfolio flows) que cobriam tanto investimentos em carteira como títulos de renda fixa. A alíquota inicial de $2 \%$ rapidamente subiu para $4 \%$ e depois para $6 \%$ em 2010 . Em 2010, o Banco Central da Turquia aumentou a exigência de reservas do sistema financeiro para diminuir o crescimento de empréstimos e a agência reguladora do sistema bancário em 2011 mudou a classificação de risco de algumas linhas de crédito para tentar diminuir o endividamento dos consumidores. Também em 2010, o Banco Central da Indonésia adotou medidas para frear os fluxos de capital implementando uma exigência temporal para que investidores ficassem pelo menos um mês com os títulos por eles adquiridos.

A entrada substancial de capitais durante os primeiros anos da década de 2010 exigiram adaptação dos instrumentos de política monetária e financeira dos países emergentes. Entretanto, foi a forte reversão dos fluxos a partir de 2013 que apresentou maiores desafios. O gosto por nomes estilizados fez com que o mercado financeiro à época, em 2013, cunhasse o termo The Fragile Five para designar as cinco economias emergentes cujas moedas estavam em risco de forte desvalorização: o real brasileiro, a rúpia indiana, a rúpia indonésia, o rand sul-africano e lira turca. A caracterização feita pelo banco Morgan Stanley se deveu ao fato de serem países com alta inflação, crescimento declinante, expostos ao desaquecimento da economia chinesa e principalmente muito dependentes de instáveis fluxos de capitais externos para financiar o seu crescimento ${ }^{1}$. Com o passar do tempo e a depender das condições internacionais, este conjunto de economias foi sendo atualizado, incluindo, entre outros, Argentina e México.

Durante este período, a partir de 2013 até o fim de 2016, todos estes países viram suas taxas de juros subirem. Alguns deles, como Argentina e Turquia, ainda passam por fragilidades externas relevantes. As taxas turcas atingiram 25\% entre 2018 e 2019, frente a uma média histórica de $10 \%$ considerando o período de 2005 até hoje. Já na Argentina, o

\footnotetext{
${ }^{1}$ para mais informações sobre essa definição: https://www.thebalance.com/what-are-the-fragile-five1978880 ; https://www.businessinsider.com/morgan-stanley-fragile-5-emerging-markets-2013-9
} 
juro nominal chegou ao patamar de $78 \%$ no terceiro semestre de 2019 , enquanto a média das taxas no mesmo período foi de $20 \%^{2}$.

Grandes contrações da demanda global, às quais estão associadas um aumento da preferência pela liquidez dos investidores internacionais, também motivam fugas de capitais das economias emergentes rumo a ativos mais seguros. O período imediatamente posterior à crise de 2008, os 90 dias que se seguiram à quebra do banco Lehman Brothers, foi marcado por uma saída de capital acumulada de US\$ 25 bilhões destes países. A crise do COVID-19, potencializada pelo choque no preço do petróleo de março de 2020, gerou de 21/01/2020 até o início de abril uma saída de US\$ 90 bilhões das economias emergentes. Também em março de 2020, cerca de 85 países foram ao Fundo Monetário Internacional (FMI) para solicitar apoio ${ }^{3}$. A forte saída de capitais ocasionou uma depreciação significativa do real que do início de 2020 até maio chegou a acumular uma desvalorização máxima de quase $50 \%$. Outras moedas de países emergentes também foram impactadas, o peso mexicano e colombiano chegaram a se desvalorizar $38 \%$ e $26 \%$ respectivamente neste ano. A lira turca, por sua vez, observou uma variação de $21 \%$, o peso argentino de $15 \%$ e a rúpia indiana de $10 \%$, todas no mesmo sentido.

Do ponto de vista teórico, o debate que a Crise de 2008 engendrou segue vivo. Destaca-se aqui a proposição de Rey (2015) de que diante de um forte ciclo financeiro global correlacionado com a política monetária dos EUA, a variação cambial não tem sido suficiente para garantir a capacidade das economias nacionais em seguirem objetivos domésticos. Parte importante do argumento se deve à existência de outros canais de transmissão da política monetária entre os países para além da balança comercial, que é o principal mecanismo de ajuste nos modelos de inspiração Mundell-Fleming. Em especial, a entrada de grande fluxos de capitais, à qual se segue uma apreciação cambial, tem também o efeito de melhorar as posições em moeda estrangeira dos balanços patrimoniais de empresas e bancos, possuindo um caráter expansionista. Da mesma forma, uma reversão dos fluxos, ao depreciar a moeda e aumentar o endividamento em moeda estrangeira das firmas, aumenta a percepção de risco, diminui a oferta de crédito e a alavancagem dos bancos.

No que diz respeito à existência de um ciclo financeiro global, a questão subjacente é explicar de que maneira operam os fluxos de capital entre países. Há uma vasta literatura que busca entender as determinações destes fluxos, em especial motivadas por aquilo que ficou conhecido como o "Paradoxo de Lucas"(LUCAS, 1990). Brevemente, o paradoxo consiste no fato de que ao contrário do que se preveria a partir de um modelo neoclássico padrão, o capital não flui uniformemente do país com menor retorno marginal (países

\footnotetext{
${ }^{2}$ Dados do Bank of Internation Settlements

${ }^{3}$ Os dados são do Institute of International Financei e podem ser acessados aqui e também deste texto da página sobre o COVID-19 do departamento de economia Universidade de Cambridge.
} 
ricos de capital abundante) para os países com maior rendimento marginal (países pobres, com capital escasso). Ao contrário, os fluxos são bastante pró-cíclicos: ampliam o boom e reforçam a recessão. Em parte, a explicação para isso se deve à importância que fatores externos ao país receptor possuem na determinação dos movimentos de capital; como propõem Gavin, Hausmann e Leiderman (1995) e também Calvo, Leiderman e Reinhart (1996). Recentemente, a literatura reforçou a relevância da política monetária dos EUA para determinação de fluxos e preços no restante do mundo diante da hegemonia do dólar no mercado internacional (GOURINCHAS; REY; SAUZET, 2019). Miranda-Agrippino e Rey (2015) mostram que existe um único fator global, influenciado pelas taxas do FED, que explica um quarto da variação de preços de ativos de risco ao redor do mundo. Jordà et al. (2019) estudam de que maneira fluxos internacionais entre as economias avançadas se correlacionam historicamente, e argumentam que a sincronia de preços de ativos atingiu seu ápice ao longo dos últimos 30 anos. Cecchetti, Griffoli e Narita (2017) mostram que o efeito de uma política monetária expansionista dos EUA de incentivar maior tomada de risco por firmas domésticas é reproduzido também, em quase igual magnitude, por firmas estrangeiras. Bernanke (2017) debate de maneira geral quais os potencias transbordamentos da política monetária do FED sobre os demais países, em especial os emergentes.

O sistema bancário e a mudança nas posições líquidas das firmas são também responsáveis pela transmissão internacional da política monetária do centro para os demais países. Em especial Cetorelli e Goldberg (2012) estudam, a partir de balanços patrimoniais de empresas, de que maneira os bancos internacionais transmitem choques de política monetária para todo o globo. Bruno e Shin (2015) discutem o chamado "risk-taking channel" de transmissão internacional de política monetária e mostram que há uma correlação inversa entre a apreciação do dólar e a oferta mundial de crédito. Em especial nos países emergentes, o descasamento entre ativos e passivos em moedas estrangeira tendem a acirrar o efeito contracionista de desvalorizações do câmbio nos balanços patrimoniais das firmas e bancos. O momento atual é representativo deste fato: segundo estimativas preliminares, a forte desvalorização do real, em um cenário em que cerca de $60 \%$ do endividamento das empresas brasileiras é denominado em dólar pressiona para baixo o lucro operacional das firmas e deteriora seus balanços ${ }^{4}$.

Esta dissertação busca contribuir para a literatura dedicada ao tema da autonomia de política monetária em países emergentes, o que será feito nos próximos três capítulos.O Capítulo 1 apresenta um levantamento histórico de parte da literatura dedicada ao tema, com o objetivo de propor uma definição para o conceito de autonomia monetária que se adeque aos propósitos deste trabalho. Uma vez estabelecida a definição, o Capítulo 2 e Capítulo 3 propõem formas alternativas de formalizar este debate. O primeiro constrói um modelo agregado para apresentar de maneira intuitiva as consequências em termos da

\footnotetext{
${ }^{4}$ Para mais informações ver, por exemplo, https://bit.ly/2XtxfAD
} 
independência da política monetária de se levar em conta, para uma autoridade monetária preocupada com inflação, elementos como o ciclo financeiro global e a existência de efeitos financeiros da variação cambial. Já o segundo apresenta um modelo novo keynesiano no qual a maior densidade analítica permite aprofundar a análise conduzida no capítulo anterior. Por fim, as Considerações Finais resumem os principais resultados obtidos na pesquisa. 


\title{
1 A questão da autonomia de política monetária em países emergentes
}

\author{
En el passado, la crítica tenía por objeto llegar a la verdad; \\ en la edad moderna, la verdad es crítica. \\ El principio que funda nuestro tiempo no es una verdad eterna, \\ sino la verdad del cambio.
}

Octavio Paz - Los Hijos del Limo

A análise feita neste capítulo busca justificar o porquê de a autonomia de política monetária constituir uma questão, em especial, para as autoridade monetárias países emergentes. A partir de um levantamento teórico não exaustivo, será apresentada uma trajetória histórica do tema. A narrativa estabelecida permite definir um conceito específico para a autonomia monetária, o qual embasará a análise dos capítulos posteriores.

\subsection{Por que autonomia de política monetária?}

O tema do ajustamente externo é central para o deabte de economia monetária internacional. Diante de desequilíbrios entre países quais os mecanismos de ajuste endógenos à operação cotidiana da economia? Qual o espaço para atuação política diante de um desequilíbrio? Quais impactos de choques externos na economia doméstica? Qual a eficácia de determinadas políticas em restaurar o equilíbrio externo e garantir objetivos domésticos? (FLANDERS, 1989). É fácil perceber que, sob autarquia, a política monetária pode ser eficaz ou não para determinado objetivo a depender de seus canais de transmissão próprios. Ela será sempre autônoma, independente, uma vez que a economia em questão não possui nenhum tipo de relação com o setor externo.

Autonomia, ou independência, é entendida como a capacidade de determinada autoridade monetária em definir seus próprios objetivos e possuir as condições de alcança-los, se adaptando aos choques externos. A discussão, dessa forma, é mais de grau do que de "gênero"; isto é: ao invés da questão se traduzir em haver autonomia em determinado país com determinadas características, passa a ser qual o nível de autonomia um conjunto de políticas enseja em certa economia (FRANKEL, 2016). Há pelo menos uma razão explícita para que determinada economia almeje certo nível de autonomia de política monetária, a saber a capacidade para perseguir seus objetivos domésticos com suficiente independência do cenário externo, sejam eles estabilidade de preços ou do produto, por exemplo. Há também motivos válidos para que, em nome de uma estabilidade externa, economias acordem em abrir mão de uma política monetária autônoma - estabilidade cambial por exemplo.

O dilema ao qual estão sujeitas as autoridades monetárias se torna então, em um mundo com mobilidade de capital, se a política monetária estará dedicada a objetivos externos ou internos (MUNDELL, 1968). Obstfeld e Taylor (1998) traduzem esta questão naquilo que ficou conhecido como o trilema da política monetária. A saber, a impossibilidade de se obter simultaneamente i) estabilidade cambial, ii) mobilidade de capitais e iii) política monetária orientada a objetivos domésticos. Os autores mostram 
que ao longo da história diferentes combinações emergiram a partir de diferentes concepções políticas e econômicas de quais seriam os melhores arranjos. O ponto iii) se tornou sinônimo de possuir autonomia de política monetária, assim como o ponto i) é comumente tratado como câmbio fixo, por fim, o item ii) é apresentado como mobilidade perfeita de capitais. Assim, o trilema nos diz que diante de determinado grau de mobilidade de capitais, a política monetária deve optar por perseguir o equilíbrio externo ou doméstico.

A partir dessa visão, o questionamento levantado por Rey (2015) pode ser posto como: será o câmbio flutuante capaz de assegurar, por si só, grau desejável de autonomia de política monetária? Dito de outra forma, o câmbio flutuante é mecanismo eficaz para permitir que a política monetária se dedique a objetivos domésticos em face às características da atual integração financeira? Caso não seja, por que isto ocorre e quais políticas podem garantir uma maior autonomia? Como será discutido em sequência, essas questões não são novas, percorrem a teoria econômica há algum tempo. Ainda assim, elementos contemporâneos trazem qualificações necessárias ao debate sobre autonomia. Finalmente, as características distintivas de economias emergentes impõem complicações adicionais para se obter o mesmo grau de autonomia da política monetária que países ricos com o mesmo regime de câmbio e integração financeira similar.

\subsection{Por que em países emergentes?}

A Introdução desta pesquisa já apresentou algumas motivações para um tratamento específico das economias emergentes no que se refere a questões de política monetária. Para além da evidência empírica da fragilidade financeira a qual estas economias estão submetidas, há elementos constitutivos de seu setor financeiro, empresarial e de suas instituições que perpetuam as disparidades entre ricos e pobres. Além disso, determinações históricas na construção do atual Sistema Monetário Internacional (SMI) definiram papéis distintos para tipos diferentes de países, como discutem Eichengreen, Hausmann e Panizza (2007). Sob outra perspectiva teórica, entende-se que estas distinções entre as economias caracterizam uma hierarquia das moedas, como discutem, por exemplo, Conti, Prates e Plihon (2014).

Por construção, as estruturas de uma economia emergente são distintas daquelas de uma economia desenvolvida. De tal maneira que a justificativa para tratar com distinção os países periféricos não deve se encerrar na constatação de que eles representam um aparato econômico particular, mas sim no entendimento que esta estrutura diferenciada exige uma análise específica, por exemplo, da questão da autonomia de política monetária. Além disso, é preciso compreender que as características distintas entre países ricos e pobres não afetam apenas a dinâmica doméstica de cada uma dessas economias, mas também a forma como se estrutura a relação entre elas. Ou ainda, a economia periférica não é simplesmente a economia central em um estágio anterior do desenvolvimento, mas o próprio atraso da primeira determina e condiciona a posição da segunda. Buscaremos ressaltar elementos tipicamente destacados pela literatura e que, em alguma medida, serão levados em consideração pela modelagem posterior ${ }^{1}$.

Em um mundo com algum nível de rigidez de preços, a moeda que denomina as transações comerciais de determinado país influencia na absorção de choques externos por parte desta economia. Gopinath et al. (2020) mostram que parte relevante das transações comerciais de países emergentes da América Latina e Ásia são precificadas em dólares, mesmo relações que não envolvem de forma alguma os EUA. Além de impactar os efeitos acomodacionistas do regime de câmbio flutuante, os autores mostram

\footnotetext{
${ }^{1}$ Do ponto de vista da constituição de um campo de estudo a partir das economias emergentes, um marco na literatura convencional é a organização do livro didático "Development Macroeconomics"de Agenor e Montiel (1996).
} 
que este fenômeno implica que uma apreciação de $1 \%$ do dólar em relação a todas as outras moedas diminui em $0,6 \%$ o volume anual do comércio entre países.

Como discutido na Introdução, variações cambiais impactam as condições financeiras das economias emergentes endividadas em moeda estrangeira. Giovanni et al. (2017) analisam a economia truca e mostram que, ao nível da firma, um aumento da liquidez internacional associado a uma depreciação do dólar aumenta o volume de empréstimos. Morais et al. (2019) estudam o caso do México e mostram que tal qual argumentado pelo risk-taking channel uma apreciação cambial melhora os balanços das empresas endividadas em dólar e aumenta o apetite de risco dos investidores. Para o caso específico do Brasil, Valle, Toneto e Cicogna (2017) mostram que ao contrário do que poderia se supor em relação ao benefício de uma desvalorização cambial para o setor exportador, o efeito negativo no balanço das firmas exportadoras brasileiras, por possuírem compromissos em moeda estrangeira, mais do que compensa, do ponto de vista da lucratividade do setor, o ganho de competitividade relacionado a uma desvalorização cambial. Os autores também mostraram que a ampliação de crédito de longo prazo por meio do Banco Nacional de Desenvolvimento Econômico e Social (BNDES) atenuou a exposição cambial das firmas.

Esta evidência empírica se relaciona com o chamado pecado original (original sin) discutido por Eichengreen, Hausmann e Panizza (2007). A tese defendida pelos autores é de que algumas economias, independentemente de suas instituições ou credibilidade, não conseguem se endividar externamente em suas próprias moedas e o fato a maioria delas não possuírem mercado de crédito de longo prazo bem desenvolvido acentua o problema. Neste artigo, os autores apresentam e diferenciam três elementos das desigualdades estruturais entre os países periféricos e centrais: o pecado original, descasamento monetário (currency mismatches) e intolerância à divida (debt intolerance). O segundo diz respeito a um descompasso entre o passivo em moeda estrangeira e os ativos disponíveis nesta mesma moeda. Um país que sofre de fortes restrições em endividamento na própria moeda, acaba acumulando passivos em dólar, por exemplo, e pode estar mais sujeito a desequilíbrios entre passivos e ativos nesta moeda. Mas isso não necessariamente acontece. Como demonstrado pelos autores, países que têm uma dificuldade de se endividar em suas próprias moedas externamente também tendem a acumular mais reservas, aliviando o descasamento entre moedas. Por fim, a intolerância à divida, como definido por Reinhart, Rogoff e Savastano (2003), diz respeito à dificuldade que muitos países periféricos possuem em gerir níveis de dívida que são absolutamente administráveis por países ricos. Este elemento se relaciona com o pecado original na medida em que a incapacidade de um país de se endividar externamente em sua própria moeda pode ser um dos elementos para uma aversão maior à dívida por parte de investidores ${ }^{2}$.

As oscilações cambiais beneficiam setores e prejudicam outros, impactam o balanço patrimonial de firmas, transmitem choques monetários externos, alteram o nível de crédito da economia e possuem também impacto no nível geral de preços. Diante da centralidade do câmbio, a teoria econômica buscou mostrar como de fato os bancos centrais se preocupam com a questão cambial e realizam, mesmo em um regime de câmbio flutuante, intervenções no mercado de câmbio no sentido de minimizar sua volatilidade. Este fenômeno ficou conhecido na literatura como "fear of floating" (CALVO; REINHART, 2002). Recentemente, Ilzetzki, Reinhart e Rogoff (2017) realizaram um levantamento de regimes cambiais e restrições no mercado de câmbio para 194 países e mostram que boa parte dos países que dizem adotar um regime flutuante oficialmente, de fato praticam substantivas intervenções no sentido de estabilizar suas moedas.

\footnotetext{
${ }^{2}$ Novamente, a literatura sobre hierarquia de moedas apresenta uma maneira robusta de se compreender este mesmo fenômeno levando em conta os papeis distintos das economias no SMI.
} 


\subsection{Uma (breve) perspectiva histórica da questão da autonomia de política monetária}

\subsubsection{Da controvérsia bullionista ao arcabouço de Mundell-Fleming}

Debates sobre fenômenos monetários internacionais acompanham a teoria econômica há muito tempo. Ricardo (1810) em "The high price of bullion" discute as causas da forte depreciação da libra esterlina observada após as guerras napoleônicas durante as quais prevaleceu um regime de câmbio flutuante na Inglaterra. A controvérsia bullionista, como ficou conhecida, debatia precisamente as causas desta depreciação e das flutuações da moeda durante o período da não paridade entre a libra e o ouro. Diferentes leituras sobre os motivos da flutuação levavam a distintas recomendações de política para reestaruar a paridade anterior. De uma lado a vertente monetarista da época, liderada por Ricardo, defendia que os excessivos déficits durante o período de guerra aumentaram a oferta de moeda e depreciaram a libra, enquanto os não-bullionistas defendiam que os motivos das flutuações tinham a ver com desconfianças em relação ao Banco da Inglaterra e aversão ao risco.

Embora este evento específico demonstre a presença do tema dos ajustamentos externos no debate econômico do início do século XIX, é ao longo século XX que o poder de agência da política econômica ganha mais espaço no meio acadêmico. Para além de mudanças na própria concepção da economia, Eichengreen (1996) aponta como o advento da democracia e a compreensão de que a política econômica faz escolhas ampliou ao longo dos anos 1920 e 1930 a relevância de temas como a eficácia da política econômica e as consequências em termos de emprego e renda de determinadas medidas. A partir desta diferenciação, Flanders (1989) caracteriza, para fins expositivos, dois percursos distintos do pensamento econômico em relação a temas de economia monetária internacional. O primeiro, iniciado nos clássicos, é focado em análises positivas, buscando entender a natureza do equilíbrio, em especial de longo prazo. O segundo seria o policy oriented que para ele começa a tomar forma no fim do século XIX com Bagehot e Marshall e se consolida no início do século XX em especial com os debates provocados pela macroeconomia keynesiana.

Na década de 1930, por exemplo, Whale (1936) e Haberler (2017)[1937] discutem que na ausência de fluxos de capitais, o câmbio flutuante permite às economias domésticas acomodarem flutuações externas. Argumentam, guardadas as diferenças, que a mobilidade de capitais dificulta este processo de acomodação na medida em que as motivações financeiras/especulativas destas oscilações não atuam de maneira a estabilizar o ciclo tal qual os fluxos comerciais. Whale (1936) chega argumentar que a ampla mobilidade de capitais seria análoga, do ponto de vista da necessidade da política monetária de servir ao equilíbrio externo, ao padrão-ouro - câmbio fixo. Haberler (2017)[1937], por outro lado, acredita que apenas em um mundo com grande sincronia do movimento de capitais o resultado da perda de autonomia se verificaria.

Na mesma década,Hayek (1937) discute a má reputação dos fluxos de capital de curto prazo e as razões desestabilizadoras destes movimentos, como pode ser observado no seguinte excerto:

\footnotetext{
It is because with "mixed"national monetary systems the movements of short term funds are frequently due not to changes in the demanda for capital fo investment, but to changes in the demand for cash as liquidity reserves that short tem international capital movements have their bad reputation as causes of monetary disturbances. And this reputation in not altogheter undeserved. (Hayek, 1937, p. 62).
}

A posição de Keynes em defesa de restrições ao livre fluxo de capitais na conferência de Bretton Woods são conhecidas ${ }^{3}$. Estava nítido, já naquele momento, a incompatibilidade entre equilíbrio externo

\footnotetext{
"In reality, Keynes and White were not far apart on the principle that capital flows might need to be
} 
e interno diante de um mundo com alta mobilidade de capitais. Dada a visão keynesiana em defesa do papel do Estado na garantia do emprego e da renda, medidas que garantem maior independência da política econômica são coerentes. A questão da autonomia pode ser observada em mais de uma passagem de "Treatise on Money" (KEYNES, 1930), como por exemplo:

This, them, is the dilemma of an international monetary system - to preserve the advantages of the stability of the local currencies of the various members of the system in terms of the international standard, and to preserve at the same time an adequate local autonomy for each member over its domestic rate of interest and its volume of foreign lending (KEYNES, 1930, p. 304)

\subsubsection{O arcabouço de Mundell-Fleming}

O novo paradigma keynesiano incorporado pela síntese neoclássica e o arcabouço IS-LM de Hicks (1937) permitiram a emergência de uma série de modelos interpretativos do funcionamento da macroeconomia. Desse processo, no âmbito da macroeconomia internacional, emerge o que ficaria conhecido como o paradigma de Mundell-Fleming, que traz para o centro da discussão econômica a escolha entre objetivos desejáveis e mutuamente excludentes, que posteriormente foram definidos pelos termos de "trindade impossível"(COHEN, 1993) ou "trilema de política monetária"(OBSTFELD; TAYLOR, 1998).

O modelo de Mundell-Fleming da forma como conhecemos foi elaborado a partir de diversas contribuições de Robert Mundell ${ }^{4}$ que foram sistematizadas em Mundell (1968) e pelo trabalho de Fleming (1962). Nesse período, por recomendação de Samuelson, Fleming convidou Mundell para integrar sua equipe econômica no FMI. Durante a década de 1960 os dois conviveram no fundo e a relação entre eles até hoje coloca em debate a primazia das ideias do modelo ${ }^{5}$. A potência e a hegemonia deste arcabouço é atribuída ao fato de ter sido uma primeira análise sistemática do papel que mobilidade de capitais e política cambial possuem na determinação da eficiência de políticas econômicas distintas (FRENKEL; RAZIN, 1987). Como apresentado por Frenkel e Razin (1987) e Boughton (2003), o modelo incorpora as contribuições de Metzler (1951) de modelos keynesiano de economias abertas e o trabalho de Meade (1951) ampliando sua análise "policy-oriented" do Balanço de Pagamentos para uma economia em que há simultaneamente troca de bens e ativos financeiros ${ }^{6}$

Ironicamente, Mundell e Fleming tinham pouco acordo sobre o desenvolvimento do modelo e realizaram seus trabalhos de maneira majoritariamente independente (MUNDELL, 2001) ${ }^{7}$. De maneira geral, havia diferenças relevantes entre os modelos propostos por cada um. Para Mundell a taxa de câmbio real era endógena uma vez que permitia que variassem os termos de troca entre as economias, o que era mantido fixo por Fleming. Além disso, Mundell caracterizava a política monetária por meio de uma

regulated, although Keynes's methods for accomplishing this task were more realistic and therefore much more dirigiste. This shared tolerant attitude toward capital account prohibitions was fully reflected in the eventual Articles of Agreement establishing the IME A major goal of the IMF system was nondiscriminatory multilateral convertibility on current account (as set out in Article VIII). But Article VI(3) stated that "members may exercise such controls as are necessary to regulate international capital movements." Article VI( 1) prohibited members from using IMF resources 'to meet a large or sustained outflow of capital' and even empowered the Fund to request imposition of capital controls in such cases." (OBSTFELD;TAYLOR 1998, p. 385).

${ }^{4}$ Por exemplo Mundell (1960), Mundell (1961) e Mundell (1963)

${ }^{5}$ Para uma discussão aprofundada sobre as origens do modelo de Mundell-Fleming ver Boughton (2003)

${ }^{6}$ Âs contribuições de Meade, Metzler e Mundel (MMM) Flanders (1989) dá o nome de confluência, no sentido de que analisam questões de curto prazo "policy-oriented"mas combinando-as com preocupações positivas e do equilíbrio de médio e longo prazo.

${ }^{7}$ A junção do nome dos dois nesta sequência é atribuída a Dornbusch (1976) e massivamente divulgada, segundo Boughton (2003), por meio do livro didático Open Economy Macroeconomics de Rudiger (1980) 
regra de juros e a relacionava com a taxa de juros internacional. Para Fleming a regra era de agregado monetário. Fleming reorienta e simplifica a análise de Meade (1951) para entender de que maneira o regime cambial torna mais ou menos efetiva as políticas fiscais e monetárias na determinação do produto. Analogamente, Mundell também tinha a preocupação em avaliar como política fiscal e monetária poderiam ser mais ou menos eficientes para estabilidade do emprego e crescimento econômico, buscando mostrar que o argumento keynesiano de primazia da política fiscal só faria sentido em um mundo de câmbio fixo ${ }^{8}$ Observa-se então que o que ficaria amplamente difundido como os casos em que há ou não autonomia da política monetária, dizem respeito, nas formulações originais, a sua efetividade ou não a depender do arranjo de políticas adotado.

A análise e as preocupações de Mundell, entretanto, vão além. Em primeiro lugar, o caso da perfeita mobilidade de capital é tratado mais amplamente por Mundell e é inclusive central para a sua discussão, enquanto aparece lateralmente no trabalho de Fleming. Em certa medida, isso se deve à nacionalidade canadense de Mundell. O Canadá foi o primeiro país a abrir mão de controles de capital e adotar uma flexibilidade cambial ainda no início dos anos 1950 e foi a posterior recessão causada por uma forte elevação da taxa de juros que motivou Mundell a pesquisar sobre a eficácia relativa das políticas monetárias e fiscais em diferentes contextos. A centralidade que o arcabouço de Mundell-Fleming passou a ter no debate sobre autonomia de política monetária se deve, segundo Rose (2000), ao "principle of effective market classification" estabelecido por Mundell que argumenta que os instrumentos de política devem ser utilizados nos mercados em que possuem maior eficácia. A aplicação deste princípio implica, no trabalho de Mundell, que a política monetária deve ser orientada, na presença de perfeita mobilidade de capitais, ou para objetivos externos ou internos e nunca para os dois ${ }^{9}$.

\subsubsection{A construção de um novo paradigma da política econômica}

Estas discussões ecoavam no debate de política econômica que vinha se consolidando com o término do mundo Bretton-Woods. Dois eram os princípios norteadores deste debate. Primeiro, a impossibilidade que muitos atestavam em sustentar controle de capitais: de um lado porque o mercado dava conta de criar meios de fugir aos controles e, de outro, por conta de uma teoria econômica que cada vez mais ressaltava os potenciais ganhos de uma maior liberalização. Em segundo lugar, o entendimento de que em um contexto de alta mobilidade era preciso garantir algum mecanismo que viabilizasse independência suficiente da política doméstica ${ }^{10}$. O resultado prático deste embate se reflete nas duas principais propostas de encaminhamento das incompatibilidades entre objetivos externos e internos. Por um lado, defende-se

\footnotetext{
${ }^{8} \mathrm{Ou}$ seja, haveria um possível trilema envolvendo a política fiscal: não se pode ter câmbio flutuante, perfeita mobilidade de capitais e uma política fiscal eficiente Este é um resultado tão imediato do modelo quanto é o trilema da política monetária. Muitos autores inclusive, ao declarar a ineficácia da política fiscal hoje, estão, em alguns casos, implicitamente se referindo a este resultado.

9 "Perhaps the most striking result of Mundell's work on monetary dynamics is his "incompatible trinity"(...). A narrow interpretation of this result would be to conclude that external and internal targets would be in conflict - the economy will not stably converge to its long-run equilibrium unless external policy is assigned to the monetary authority. But a broader interpretation of this result is appropriate, since Mundell's principle explicitly delineates the trade-offs facing central banks in the most sweeping sense. In the presence of mobile capital, monetary policy can either be oriented towards an external goal (such as exchange rate stability) or an internal objective, but not both. The result now stands as one of the undisputed foundations of international monetary analysis. Academic take it for granted. (ROSE, 2000, p. 215)."

${ }^{10}$ Do ponto de vista da história monetária este período é bastante complexo, eventos como os choques do petróleo, os acordos de Plaza, a crise da dívida nos países emergentes, são o substrato material em cima do qual os debates teóricos se concretizam. Para maior referência ver, por exemplo, Eichengreen (1996) ou Helleiner (1996).
} 
um regime de câmbio flutuante em que a autonomia da política monetária estaria teoricamente garantida ao mesmo tempo em que seria possível usufruir dos potenciais ganhos da mobilidade de capitais. De outro, a criação de um sistema internacional cooperativo, formado por uniões monetárias cada vez mais amplas de tal forma que se sacrificaria a autonomia da política monetária, mas se garantiria o completa paridade cambial e coordenação dos fluxos comerciais e de capitais ${ }^{11}$.

Mantiveram-se, as ressalvas em relação ao potencial garantidor de independência política do regime de câmbio flexível junto de mobilidade de capitais. Flanders (1974) argumenta de maneira quase premonitória que a decepção com a capacidade de autonomia garantida por acomodações do câmbio era, em sua maioria, decorrência de expectativas irreais em relação a este instrumento. Flanders (1989) reforça que há uma inconsistência teórica, dada as características dos fluxos de capital e imperfeições de mercado, em acreditar que o poder acomodacionista do câmbio seria equivalente para os fluxos comerciais e financeiros. Recuperando o debate dos anos 1930, Tornell (1990) aponta que os movimento de capitais de curto prazo são mais motivados por rumores e expectativas do que pelos "fundamentos"propriamente ditos. Tendo estes elementos em vista e preocupado com os perigos da característica "hot money"dos fluxos de capital, Tobin (1978) em sua proposta para o SMI sugere a adequação de uma taxa sobre a movimentações financeiras internacionais a fim de desincentivar movimentos puramente especulativos de curto prazo.

A partir deste período, começam a pulverizar análises esquemáticas dos trade-offs debatidos pela economia monetária internacional. Os trabalhos de Schioppa (1985) e Schioppa (1988) argumentam sobre a existência da "A quadratura do Círculo" ou "Quarteto Inconsistente". O autor atestava a impossibilidade de se obter (1) livre comércio, (2) plena mobilidade de capitais, (3) câmbio fixo ou administrado, (4) autonomia de política monetária, isso é, o trilema acrescido do livre comércio, o que segundo Schioppa (1988) obrigaria os países a escolher duas das quatro ${ }^{12}$. Mais adiante, Cohen (1993) formaliza o conceito da Trindade Impossível ( "Unholy Trinity") como podemos observar neste excerto de uma reedição do artigo de 1993, Cohen (2002):

The main premise of this chapter is that international monetary cooperation, like passionate love, is a good thing but difficult to sustain. The reason, I argue, is systematic and has to do with the intrinsic incompatibility of three key desiderata of governments: exchange-rate stability, capital mobility, and national policy autonomy. Together these three values form a kind of "Unholy Trinity" that operates regularly to erode collective commitments to monetary collaboration. (COHEN, 2000, p.246).

Foi na esteira deste processo que Obstfeld e Taylor (1998) sistematizam o conceito do Trilema da Política Monetária que constitui o termo por meio do qual os debates históricos da literatura narrados nesta seção, formalizados de maneira mais conhecida no arcabouço de Mundell-Fleming, passaram a ser denominados. A virada do século XX para o XXI representou também o processo de hegemonização do câmbio flutuante como a maneira de melhor insular as economias diante da liberalização também crescente das contas capitais. Foi com boa dose de otimismo que a nova formatação foi recebida pela teoria, entusiasmo que podemos observar por exemplo no mesmo artigo em que se define o "trilema":

\footnotetext{
${ }^{11}$ Essa discussão ganha força nos anos 1980 em meio ao debate sobre o Sistema Monetário Europeu e a possibilidade prática de se implementarem áreas ótimas de moedas comuns (Optimum Currency Area -OCA), debate no qual Mundell teve grande inserção.

${ }^{12} \mathrm{O}$ avanço do debate acabou por tirar o livre comércio da equação, embora possa ser um elemento importante a depender do grau de comércio entre dois países para entender a transmissão da política monetária entre eles. De outra forma, pensando em termos do modelo MF, o comércio é a outra face do fluxo de capitais por meio do equilíbrio do balanço de pagamentos e da igualdade entre poupança e investimento. Entretanto, ao contrário da conta de capitais, a conta corrente possuí ajuste mais lento - sua determinação depende endogenamente das condições de demanda e oferta do país e do ajuste do câmbio - o que favorece o estabelecimento na literatura da conta capital e do câmbio como variáveis de ajustes no curto prazo de desequilíbrios externos.
} 
While the current system is not free of shortcomings, it has allowed sovereign nations to coexist and, where they have liberalized and opened their economies, to begin converging. Moreover, a replay of the Great Depression has been avoided so far. It is ironic that the current international system sprung directly from one based on disillusion with the interwar performance of free capital mobility and floating exchange rates alike. Thus Keynes's remark in closing the Bretton Woods conference may still be appropriate: "How much better that our projects should begin in disillusion than that they should end in it!" (OBSTFELD; TAYLOR, 1998, p. 397-398).

Não seria correto, entretanto, supor que haviam sido esquecidas as limitações que mesmo o regime de câmbio flutuante teria em garantir o livre exercício da política monetária em face da liberalização financeira. Ao contrário, o caráter disciplinador deste esquema institucional constituía justamente um argumento em defesa da combinação. De tal modo que a autonomia ensejada pela livre variação cambial era suficientemente limitada para que não permitisse arrochos populistas, nos termos de Dornbusch e Edwards (1991). Ao longo dos anos 1990, diversos artigos buscaram reforçar os ganhos associados com uma maior integração financeira, apresentando que essa geraria diversificação de risco, suavização do consumo para os países com restrições de crédito e disciplina fiscal para políticos "míopes e oportunistas". Em um aparente paradoxo, a limitação da autonomia é considerada um ponto importante para que se advogue pela liberalização. Dois artigos neste sentido são Fischer (1997) e Dornbusch (1998), este segundo denominado: "Capital Controls: An Idea Whose Time is Past".

O debate sobre autonomia de política monetária foi pautado desde os últimos anos do século até a crise de 2008 pela incerteza acerca dos impactos da ampla mobilidade de capitais. Os países emergentes desempenharam papel central na discussão uma vez que, como discutido na Introdução, o efeito de uma melhora alocativa do capital previsto pelo modelo neoclássico deveria engendrar uma elevação do investimento garantindo uma nova trajetória de crescimento mais robusto, caminhando rumo à convergência, tal qual sugerem Obstfeld e Rogoff (1995) e Summers (2000).

Do lado mais cético aos benefícios da integração financeira, Rodrik et al. (1998) e Stiglitz (2004) discutem os riscos financeiros para as economias emergentes e as fragilidades práticas do argumento neoclássico teórico sobre os efeitos significativos no crescimento. Estes artigos, e boa parte da literatura - desde Hayek pelo menos, como visto - diferenciam os efeitos de capitais de curto prazo dos fluxos de investimento, sendo o segundo desejável e o primeiro perigoso. Permitir o ingresso de um, mas barrar o outro, entretanto, não é uma tarefa simples.

Uma revisão ampla das evidências em relação a este tema para este período pode ser encontrada em Arteta, Eichengreen e Wyplosz (2001) e Kose et al. (2009), nas quais há um indicativo de que, em geral, os efeitos da liberalização financeira sobre o crescimento são modestos, ou inexistentes. Em discordância com estes resultados e em defesa dos benefícios de uma maior mobilidade de capitais, Henry (2007) aponta que há problemas nas estimações conduzidas até aqui por focaram muito nos efeitos sobre o crescimento de longo prazo, ao invés de observarem o salto de crescimento no curto prazo que de acordo com suas estimativas é existente e significante. A ideia é que ao medir a tendência do crescimento de longo prazo, os estudos não observavam o deslocamento da trajetória mais imediata e decorrente da liberalização. Para o caso específico do Brasil, Goldfajn e Minella (2005) apontam que a liberalização dos fluxos de capital em conjunto com a adoção do câmbio flexível tornaram a economia brasileira mais estável na acomodação dos choques externos.

Ao mesmo tempo em que houve uma explosão de novas evidências sobre mobilidade de capitais, abriu-se espaço para que novas hipóteses sobre o funcionamento do sistema financeiro internacional emergissem. Novamente, o debate focado nos países emergentes buscava responder quais características impediam a assimilação do tradicional efeito pró-crescimento da liberalização, de que maneira operavam os regimes de câmbio flutuante e quais eram os determinantes dos movimentos de capital. Este debate, 
que já foi apresentado na seção 1.2, trouxe conceitos como o "original sin", "debt intolerance", "fear of floating" e reforçou aquilo que já era discutido há pelo menos algumas décadas de que os movimentos dos capitais de curto prazo tinham outras determinações que não apenas os fundamentos de cada economia.

\subsubsection{Autonomia de política monetária: "what have we learned?"13}

A crise de 2008 foi um divisor de águas para o debate econômico sobre finanças internacionais ${ }^{14}$. No que diz respeito à autonomia da política monetária, tal qual a crise dos países emergentes dos $1990 \mathrm{e}$ o conseguinte estabelecimento do regime de câmbio flutuante junto de flexibilização da conta capital, a Grande Recessão e as diversas políticas monetárias não convencionais que se seguiram reorientaram o foco das pesquisas dedicadas ao estudo da independência entre países. A enorme instabilidade provocada pelo Quantative Easing e posteriormente pelo Taper Tatrum evidenciaram que as dificuldades vividas pelas economias emergentes mesmo com o câmbio flutuante.

Sinteticamente, há dois caminhos traçados pela literatura recente, cada um dos quais se divide por sua vez em duas possibilidades. O primeiro diz respeito ao debate teórico sobre a validade do trilema de Mundell-Fleming. Mais precisamente, a discussão é se em meio ao atual estado de integração financeira o regime de câmbio flutuante oferece autonomia suficiente para as autoridades monetárias. A proponente contemporânea da hipótese da não validade do trilema, Rey (2015), aponta para não capacidade do câmbio flexível de insular as economias de choques externos se alicerceando na forte evidência de que os fluxos de capital são coordenados e vinculados à política monetária estadunidense, tal que previa Haberler (2017)[1937]. Do outro lado, Obstfeld (2015) argumenta que o câmbio desempenha papel relevante na garantia de uma melhor assimilação dos choques externos mas que de fato há uma insuficiência da flutuação do câmbio de acomodar simultaneamente choques monetários e financeiros, o que enseja um debate mais amplo sobre políticas alternativas.

Após a constatação empírica de Rey (2015) e Miranda-Agrippino e Rey (2015) da existência de um dilema entre abertura financeira e autonomia da política monetária, outros trabalhos buscaram testar essa hipótese. Edwards (2015) sustenta a existência de um dilema deste tipo para os países da América Latina. Han e Wei (2018) encontram o que chamam de "dilema e meio", ou seja, que o câmbio flexível falha em garantir autonomia da política monetária em resposta a um choque expansionista da política monetária do país central. De outra forma, diante de um choque contracionista, o câmbio flexível garante uma melhor acomodação ensejando maior autonomia da política monetária. Contrariamente a hipótese, Georgiadis e Mehl (2015) e Aizenman, Chinn e Ito (2016), por exemplo, sustentam que o câmbio flexível garante uma independência substantiva para a autoridade monetária. Rey (2016) responde a parte destes artigos argumentando que o teste preciso seria entender se o nível de autonomia de política monetária garantido pelo câmbio flutuante é suficiente para a acomodação eficaz do tipo de choque externo aos quais estão submetidas às economias. Neste mesmo sentido Frankel (2016) argumenta que a autonomia deve ser entendida como a capacidade de determinado país de, após a acomodação de um choque externo, manter os mesmos objetivos domésticos. Um elemento central para a discussão é de que forma a política monetária dos EUA pauta as relações comerciais e financeiras internacionais. Gourinchas, Rey e Sauzet (2019) realizam um amplo levantamento do que a literatura havia debatido sobre o tema até então e apresentam diferentes implicações para esta possível hegemonia.

O debate sobre as alternativas existentes para ampliar ou garantir a autonomia da política monetária constitui o segundo caminho ao qual nos referimos. Tal qual Eichengreen e Esteves (2019) argumentam que mesmo sob o padrão-ouro a Inglaterra conseguia manter a conversibilidade a uma taxa

\footnotetext{
${ }^{13}$ Blanchard et al. (2014)

${ }^{14}$ Com este mesmo sentido, Obstfeld (1998) denominam a crise de 1929 de "watershed"
} 
fixa e desfrutar de autonomia monetária por conta das suas enormes reservas metálicas, a literatura recente mostra que os países acumularam grandes reservas internacionais no período anterior à crise usufruíram de uma maior independência no período posterior ao choque (AIZENMAN, 2013). O canal da acumulação de reservas se efetiva na acomodação dos choques externos via intervenções no mercado de câmbio (FXI). Uma série de estudos buscou estimar a efetividade destas operações. Blanchard, Adler et al. (2015) mostram que o uso de FXI atenuou os impactos da enxurrada de liquidez do início dos anos 2010 nas economias emergentes. Aizenman e Hutchison (2012) por outro lado, argumentam que ainda que as FXI tenham sido bastante utilizadas, a absorção dos choques externos se deu majoritariamente via flutuações da taxa de câmbio, o que eles sugerem estar conectado a um medo de perder reservas ${ }^{15}$. Do ponto de vista teórico, Obstfeld, Shambaugh e Taylor (2010) apresentam uma racionalidade para o grande acúmulo de reservas observado nos páises periféricos como sendo uma forma de garantir estabilidade financeira. No mesmo espírito, Benigno e Fornaro (2012) constroem um arcabouço em que por meio do uso da política cambial possibilitada pelo acúmulo de reservas, determinado país pode acelerar o crescimento econômico. Por fim, o modelo proposto por Ghosh, Ostry e Chamon (2016) sugerem que diante de dois objetivos desejáveis, estabilidade cambial e de preços, as FXI aumentam o bem-estar, suavizando as variações da taxa de câmbio e auxiliando a efetividade da política monetária.

A outra alternativa largamente discutida pela literatura são os controles de capital, de tal forma que o debate do pós crise reorienta a discussão do início do século XXI: enquanto lá o foco do debate eram os potenciais benefícios da liberalização financeira, agora o objetivo é entender se a estabilidade financeira permitida por meio de uma administração da conta capital é vantajosa em relação aos potenciais benefícios de uma ampla abertura.

Rebucci e Ma (2019) realizam uma ampla e cuidadosa revisão e classificação da literatura dedicada aos controles de capital no pós-crise ${ }^{16}$. Mostram que do ponto de vista teórico essas medidas podem ser efetivas na prevenção de instabilidade financeira provocadas por choques externos. A existência de mercados incompletos e outras fricções faz com que os controles de capital possam melhorar o bem-estar e aumentar a autonomia da política monetária. Além disso, o desenvolvimento teórico tem apontado novos canais por meio dos quais medidas macroprudenciais se efetivam, melhorando assim a identificação empírica.

Os estudos econométricos apontam, por exemplo, que os controles de capital são efetivos para a reduzir a vulnerabilidade financeira das economias, como em Forbes, Fratzscher e Straub (2015), e também alteram o portfólio das firmas no sentido de minimizar dívidas em moeda externa tal qual discutem Bacchetta, Cordonier e Merrouche (2019). Em Zeev (2017), controles de capital são efetivos na absorção de choques externos diminuindo o custo da transição de volta ao equilíbrio após a perturbação inicial. Chamon e Garcia (2016) realizam um estudo de caso para o Brasil e apresentam que os controle de capital adotados no início dos anos 2010 foram efetivos em segmentar o mercado financeiro brasileiro do resto do mundo, conferindo um nível maior de autonomia monetária e contribuindo para a desejada desvalorização cambial da época. Já Alfaro, Chari e Kanczuk (2017) mostram que essa mesma medida esteve associada a uma piora das condições de financiamento das firmas e que o retorno das ações das empresas analisadas teve uma piora motivada pela política. De modo geral, Rebucci e Ma (2019) indicam que os resultados empíricos em relação à ampliação da autonomia de política monetária são existentes, embora muito longe de substituírem a flexibilidade do câmbio como mecanismos de absorção de choques externos. Empiricamente o seu uso tem sido justificado em especial como forma de garantir estabilidade

\footnotetext{
${ }^{15}$ Para um extenso levantamento dos estudos empíricos sobre o papel das reservas e intervenções no mercado de câmbio ver Menkhoff (2013).

${ }^{16}$ uma discussão interessante sobre de que maneira os controles de capital eram discutidos empírica e teoricamente pré-crise pode ser encontrada em Magud, Reinhart e Rogoff (2011)
} 
financeira e tornar a economia doméstica menos exposta a variações cambiais.

Um intuição compartilhada por parte relevante da literatura teórica é de que diante da existência de alguma externalidade relacionada ao financiamento externo, medidas alternativas como controles de capital podem aumentar a eficiência econômica. Uma vertente da literatura foca em externalidades pecuniárias, relacionadas à existência de uma collateral constraint ao financiamento externo. A ideia é que ao se endividarem os agentes não internalizam o custo de uma alavancagem mais elevada e que pode tornar a restrição ativa na ocasião de um choque negativo, isto é, há uma externalidade da ação individual sobre o valor de mercado do colateral. Um exemplo recente deste tipo de modelo é desenvolvido por Dávila e Korinek (). Vale ressaltar que boa parte destes modelos tratam apenas da economia real e não atribuem papel relevante para política monetária. De outro lado, externalidades de demanda existentes em uma economia com rigidez de preços e poder de mercado nas quais os agentes não internalizam a contribuição do seu endividamento e aumento de consumo para o boom tornam a reversão mais dramática. Nestes modelos, controles de capital operam como medidas macroprudenciais sobre o nível de crédito da economia e podem ser mais desejáveis caso a autoridade monetária tenha alguma outra restrição como câmbio fixo ou o zero lower bound. Farhi e Werning (2016) propõem um arcabouço que busca generalizar este caso. Combinando diferentes intuições da literatura teórica e evidências empíricas, os modelos de Aoki, Benigno e Kiyotaki (2016) e Landi (2017) estudam, em um mundo de friç̧ões financeiras e imperfeições de mercado, a interação entre política monetária e medidas macroprudenciais. Os artigos mostram que a coordenação entre instrumentos amplia a autonomia da política monetária e melhora o bem-estar das economias analisadas.

\subsection{Uma possível definição para a autonomia de política monetária}

Este capítulo, além de motivação para o restante da pesquisa, buscou apresentar de que maneira o objeto estudado nesta dissertação se articula internamente à teoria econômica e se desenvolveu ao longo do tempo. A reconstrução da literatura permite uma compreensão histórica dos problemas associados à garantia de autonomia de política monetária por todo o mundo, em especial nos países emergentes. Dilemas entre objetivos externos e domésticos e desequilíbrios entre países são a motivação de fundo do campo de pesquisa.

A partir da análise conduzida, propomos uma maneira de definir a autonomia de política monetária dos países que abarque a diversidade de interpretações que perpassaram o tema ao longo do tempo ${ }^{17}$. Autonomia se refere à capacidade de acomodação de um choque externo por meio de determinada economia doméstica. De tal maneira que uma economia é tão mais autônoma quanto menor o custo associado ao percurso que vai do choque ao retorno ao equilíbrio anterior, tudo o mais constante. Políticas que ampliem a autonomia da política monetária são políticas que atenuam o peso da transição.

A definição proposta trata a autonomia monetária como uma questão de grau e não dicotômica, o que sugere que ela deva ser analisada de maneira relativa e não absoluta, da mesma maneira que diversos estudos apontam que se deve olhar para o regime cambial e a mobilidade de capitais. Na classificação proposta aqui, por exemplo, o que é entendido como eficácia da política monetária para Mundell - que na linguagem dos anos 1990 se tornou autonomia de maneira genérica - seria um caso específico em que a autonomia é suficiente para num curto espaço de tempo retornar às condições da economia anteriores ao choque externo. Há uma miríade de combinações entre características institucionais e decisões políticas

\footnotetext{
${ }^{17}$ Como dito por Flanders (1989) o progresso da economia em geral, mas em especial desta subdivisão, não é de forma alguma linear, em larga medida, acreditamos, pois a história não se comporta de maneira retilínea e os desafios impostos pelo presente pautam amplamente as questões acadêmicas.
} 
que implicam diferentes níveis de autonomia, variando inclusive a depender do tipo do choque externo. O desafio dos capítulos seguintes é apresentar uma formalização analítica capaz de avaliar o grau de independência ensejado por determinada estrutura econômica, com relações específicas com o resto do mundo e diante de um certo conjunto de políticas. 


\section{Modelo Agregado}

\subsection{Introdução}

O objetivo deste capítulo e do próximo é formalizar por meio de um modelos teóricos a evidência debatida no Capítulo 1, buscando entender de que forma alternativas de política monetária e financeira podem auxiliar autoridades monetárias emergentes no cumprimento de seus objetivos. Como apresentado, em uma parcela significativa de países elementos como o pecado original, a formação de preços dependente da taxa de câmbio, o maior prêmio de risco associados à sua dívida e o elevado passivo das firmas em moeda estrangeira exigem um refinamento do arcabouço paradigmático utilizado para analisar os países centrais. O esforço analítico realizado busca compreender, desde este ponto de vista, os impactos macroeconômicos das desigualdades estruturais entre países.

Nesta primeira etapa constrói-se o modelo que daqui em diante será denominado o Modelo Agregado, que serve majoritariamente como motivação para a análise posterior, não se pretende complexo por princípio e busca explicitar, para este determinado arcabouço, quais os trade-offs associados a uma integração financeira pautada pelas características observadas em economias emergentes. Este modelo segue a estrutura de trabalhos recentes dedicados a inter-relação entre a política monetária dos EUA e países emergentes como Blanchard (2016) e Bernanke (2017). Em especial, desenvolve-se a partir da estrutura apresentada em Gourinchas (2018) na qual analisa a economia chilena.

No artigo de referência, é incorporado o elemento do ciclo financeiro global e a existência de financial spillovers da variação cambial para entender uma economia cuja autoridade monetária busca minimizar desvios do produto e valoriza superávits na balança comercial. O autor busca entender se, para determinada configuração de parâmetros, o regime de câmbio fixo se torna preferível ao regime de câmbio flutuante mesmo em uma economia com conta capital aberta. A ideia portanto é testar a validade absoluta da proposição de Mundell-Fleming, ao ponto de se inverter o resultado estabelecido pelo trilema de política monetária. O resultado encontrado é de que quando os financial spillovers são fortes o suficiente para tornar a transmissão da política monetária perversa, isto é, quando um amento da taxa de juros aquece a demanda agregada via apreciação cambial, é que se verifica uma incapacidade do câmbio flutuante de insular as economias ${ }^{1}$. Nos casos em que estes spillovers não são tão fortes, o câmbio flutuante ainda é a melhor alternativa para a economia descrita. A posterior calibragem de um modelo Novo Keynesiano permite ao autor inferir de que este último cenário é o mais provável para economia chilena.

Partindo de outra interpretação sobre o debate do dilema de Rey (2015), como sugerem Rey (2016) e Frankel (2016), entende-se que a hipótese do dilema implica que o câmbio flutuante por si só não é capaz de garantir plena autonomia de política monetária, devendo ser acompanhado de outras políticas como controles da conta capital e medidas macroprudenciais. Dessa forma, o Modelo Agregado aqui desenvolvido analisa os impactos da adoção de controles capital, e não de distintos regimes cambiais . Além disso, na tentativa de melhor interpretar o caso brasileiro, a autoridade monetária tem como preocupação minimizar desvios do produto e da inflação em relação ao seu potencial, incorporando a taxa de câmbio como um dos determinantes do nível de preços. Ao levar a inflação em conta, abre-se um canal adicional em relação ao modelo de Gourinchas (2018) para impactos de choques externos na função objetivo da autoridade monetária via repasse cambial. A importância deste canal é recorrente em

\footnotetext{
${ }^{1}$ Para uma discussão maior sobre a transmissão perversa da política monetária ver por exemplo Gudmundsson (2017)
} 
declarações e documentos do Banco Central do Brasil e na literatura dedicada a entender os mecanismos de transmissão da política monetária no país, por exemplo, Figueiredo e Gouvea (2011); Braga (2011); Freddo (2019).

\subsection{O Modelo Agregado}

A partir de um modelo agregado inspirado no paradigma Mundell-Fleming, buscou-se apresentar uma autoridade monetária que se preocupa,para além de desvios do produto, com desvios da taxa inflação - que por sua vez é em parte determinada por flutuações do câmbio. Considera-se também um país em que variação cambial tem desdobramentos financeiros, financial spillovers, e cujos títulos estão sujeitos a um prêmio de risco dependente da política monetária do país central, o cilo financeiro global. Este modelo pode ser visto como uma extensão do arcabouço Mundell-Fleming apresentado por livros didáticos como em Carlin e Soskice (2012).

Seguindo Gourinchas (2018), construímos um modelo de dois países em que um é uma economia pequena e aberta e outro uma economia grande que opera, em relação ao país pequeno, como uma economia fechada. A economia aberta será a economia doméstica deste modelo. A economia grande, cujas variáveis serão marcadas por um asterisco $(*)$, será a economia estrangeira. A economia é descrita por um modelo linear acrescido de uma autoridade monetária que pondera perdas quadráticas. Consideraremos que, em equilíbrio, todas as variáveis valem 0 , sendo entendidas como desvios de seus respectivos valores de estado estacionário. Os choques que serão descritos possuem média zero e a o valor futuro esperado de uma variável é igual a ela mesma no presente, $\mathbb{E}\left(x_{t+1}\right)=x$, dessa forma abstrairemos de valores esperados tradicionalmente utilizados em algumas relações, como inflação esperada e câmbio esperado.

As seguintes equações definem as economias no caso mais geral:

$$
\begin{aligned}
Y & =A+N X \\
A & =G-c R-f E \\
N X & =a\left(Y^{*}-Y\right)+b E \\
Y^{*} & =A^{*}=G^{*}-c^{*} R^{*} \\
E & =d\left(R^{*}-R\right)-d \pi+V\left(R^{*}\right)
\end{aligned}
$$

O produto doméstico, $Y$, é igual à absorção doméstica, $A$, somada à balança de transações correntes. $A$ é composta por $G$, um termo de gastos autônomos, $c$ é a sensibilidade da demanda à taxa de juros doméstica $R, f$ é uma medida dos financial spillovers e $E$ a taxa de câmbio real. O saldo em transações correntes, $N X$, depende do diferencial de produto interno e externo, $Y^{*}$, multiplicado por um parâmetro $a$; além de ser afetado positivamente diante de uma depreciação cambial, aumento de $E$, seguindo a tradicional condição de Marshall-Lerner garantida por $b>0$. O produto externo é caracterizado apenas por sua absorção doméstica $A^{*}$, uma vez que se trata de uma economia fechada do ponto de vista deste modelo. $A^{*}$ é a soma entre o componente autônomo $G^{*}$ menos o impacto negativo da taxa de juros externa $R^{*}$ sobre a demanda agregada estrangeira.

A equação de determinação da taxa de câmbio merece mais atenção. $E$, como foi dito, é a taxa de câmbio real e pode ser definida, de maneira linearizada, como $E=\pi^{*}+e-\pi$. Isto é, a taxa de câmbio real varia com a inflação externa, $\pi^{*}$, a taxa de câmbio nominal, $e$, e a inflação doméstica, $\pi$. Seguindo 
Blanchard (2016) podemos definir a taxa de câmbio nominal $e$, por meio de uma paridade descoberta da taxa de juros (UIP, na sigla em inglês) com prêmio de risco da seguinte forma:

$$
e=d\left(i^{*}-i\right)+V\left(R^{*}\right)
$$

Em que a taxa de câmbio nominal varia de acordo com o diferencial da taxa de juros nominal, multiplicado por um termo positivo $d$, que pode ser interpretado como uma medida da persistência esperada deste diferencial, mais um prêmio de risco $V\left(R^{*}\right)$. Entende-se $V\left(R^{*}\right)$ como um prêmio de risco associado aos títulos da economia doméstica e que é dependente da taxa de juros estrangeira. Incorpora-se assim o fenômeno observado pela literatura quanto à existência de um ciclo financeiro global dependente da política monetária estadunidense tal que:

$$
V\left(R^{*}\right)=g R^{*}+\chi
$$

Isto é, o prêmio de risco varia positivamente com uma elevação da taxa de juros estrangeira e segundo um choque aleatório $\chi$ cujas propriedades serão melhores definidas oportunamente. Retomando a $U I P$, sabemos pela equação de Fisher que $i=R+\pi$ e analogamente, $i^{*}=R^{*}+\pi^{*}$. Assumindo que $\pi^{*}$ é constante igual a zero e substituindo (6) e (7) na regra de determinação do cambio real, $E$, chegamos a equação (8) que nada mais é do que (5) $\operatorname{com} V\left(R^{*}\right)$ discriminado:

$$
E=d\left(R^{*}-R\right)-d \pi+g R^{*}+\chi
$$

Adicionalmente, definiremos a inflação doméstica seguindo uma Curva de Phillips acrescida de um termo dependente da taxa de câmbio seguindo a intuição de Bofinger, Mayer e Wollmershäuser (2009)² e a evidência descrita anteriormente para o Brasil. Temos que:

$$
\pi=\gamma Y+\delta e+v^{3}
$$

Por fim, diante da estrutura da economia definida por este modelo, a autoridade monetária agirá no sentido de minimizar a seguinte loss function em que lambda é um fator de ponderação positivo.

$$
L=\mathbb{E}\left[(\pi)^{2}\right]+\lambda\left[\mathbb{E}\left(Y^{2}\right)\right]
$$

O esforço analítico subsequente destina-se a comparar de que maneira controles de capital tornam, neste cenário, mais fácil para a autoridade monetária minimizar a função perda.

\footnotetext{
${ }^{2}$ Assuma que uma fração $\delta$ do consumo doméstico é importado, ou ainda que uma parcela $\delta$ da produção uiltiza-se de importações cujo custo é inteiramente repassado aso preços. Têm-se que a inflação doméstica é igual a $\pi_{d}=\gamma_{d} Y+v_{d}$, e a inflação total, $\pi$, é uma ponderação entre a inflação doméstica e a inflação externa expressa em moeda nacional, $\operatorname{logo} \pi=(1-\delta) \pi_{d}+\delta\left(\pi^{*}+E\right)$. Sabendo que $\pi^{*}=0$, e que $\gamma=\gamma_{d}-\delta$ e $v=(1-\delta) v_{d}$ chegamos à equação (9).

${ }^{3}$ Onde $v$ é um choque de oferta de média zero e variância $\sigma_{v}^{2}$ Este choque será desconsiderado nesta seção.
} 


\subsubsection{Solução do modelo}

Partindo da equação (8), torna-se o câmbio real, $E$, dependente apenas do produto, via substituição da inflação pela equação (9). De tal forma que:

$$
E=\omega_{e}\left(d\left(R^{*}-R\right)-d \gamma Y+g R^{*}+\eta\right)
$$

Na qual $\omega_{e}=\frac{1}{1+d \delta}$ e $\eta=\chi-d v$. Resolvendo o modelo em relação ao produto chega-se a seguinte relação:

$$
Y=\omega_{y}\left[G+a G^{*}+\left(\omega_{e} d(f-b)-c\right) R+\left(\omega_{e}(d(b-f)+g(b-f))-a c^{*}\right) R^{*}+\omega_{e}(b-f) \eta\right]
$$

Sendo $\omega_{y}=\frac{1}{1+a+\omega_{e} d \gamma(b-f)}$. A equação acima permite observar que, para valores relativamente altos de $f$, isto é, para uma economia com financial spillovers muito relevantes, a transmissão da política monetária se torna perversa, como discutido por Gourinchas (2018). Isto é, o efeito de uma desvalorização cambial nas firmas é muito mais recessivo do que o ganho de competitividade ensejado pela queda da moeda doméstica. Analisaremos nas simulações numéricas valores distintos de $f$ para verificar seus impactos sobre a economia, mas considerando que o impacto de um aumento de juros doméstico sobre a demanda será sempre negativo. De outro modo, o efeito competitividade pode não ser grande o suficiente para compensar o caráter recessivo de um aumento do juros externo sobre a demanda internacional e nas condições financeiras da economia doméstica. Ou seja, contradizendo o princípio clássico do paradigma de Mundell-Fleming, uma elevação do juros externo pode ser recessiva para a economia doméstica ${ }^{4}$. Formalmente temos que:

$$
\begin{aligned}
\Gamma_{R} & \equiv \frac{\partial Y}{\partial R}=\omega_{y}\left(\omega_{e} d(f-b)-c\right)<0 \\
\Gamma_{R^{*}} & \equiv \frac{\partial Y}{\partial R^{*}}=\omega_{y}\left(\omega_{e}(d(b-f)+g(b-f))-a c^{*}\right) \lesseqgtr 0
\end{aligned}
$$

Diante disso, analisaremos a otimização da autoridade monetária. O objetivo da política monetária é minimizar sua função perda tendo o juros doméstico como seu instrumento ${ }^{5}$ :

$$
\underset{\operatorname{minR}}{L}=\mathbb{E}\left(\pi^{2}\right)+\lambda \mathbb{E}\left(Y^{2}\right)
$$

Sob previsão perfeita, torna-se equivalente a:

$$
\left.\underset{\min R}{L}=(\gamma Y+\delta E)^{2}\right)+\lambda\left(Y^{2}\right)
$$

De tal forma que, no ótimo, deve valer a seguinte relação entre produto e taxa de câmbio, em que $\Gamma_{E} \equiv \frac{\partial E}{\partial R}$.

$$
Y=-\frac{\left[\gamma \delta \Gamma_{R}+\delta^{2} \Gamma_{E}\right]}{\left[\left(\gamma^{2}+\lambda\right) \Gamma_{R}+\gamma \delta \Gamma_{E}\right]} E
$$

\footnotetext{
${ }^{4}$ Krugman (2014) argumenta que o efeito é positivo mesmo diante existência de financial spillovers

${ }^{5} \mathrm{~A}$ autoridade monetária tem de fato como seu instrumento o juros nominal, $i$. Entretanto, o resultado é equivalente uma vez que, a substituição do câmbio real pelo câmbio nominal e juros real por juros nominal nas equações acima implica apenas um ajuste no valor dos parâmetros, de tal forma que podemos imaginar que a autoridade monetária opera como se escolhendo o juros real para valores de parâmetros ajustados. Essa equivalência está demonstrada no Apêndice A
} 
como assumimos que $\Gamma_{R}$ e $\Gamma_{E}$ são sempre menores do que zero, essa relação também é negativa. Para a derivação completa, ir ao Apêndice B. Esta condição, de uma relação inversa entre câmbio real e produto é análoga àquela derivada por Carlin e Soskice (2005) a partir do mercado de trabalho. Observa-se, portanto, que o repasse cambial para inflação resulta, sob hipóteses convencionais, em uma relação inversa entre desvalorização cambial e produto na otimização da autoridade monetária.

Além disso, retomando a equação (16), no caso em que não há perfeita previsibilidade, chegamos na seguinte função objetivo da autoridade monetária: $L=\left(\gamma^{2}+\lambda\right) \mathbb{E}\left(Y^{2}\right)+\delta^{2} \mathbb{E}\left(E^{2}\right)+2 \gamma^{\prime} \delta^{\prime} \mathbb{E}(Y E)$. Como por hipótese $\mathbb{E}(Y)=\mathbb{E}(E)=0$ têm-se que:

$$
\min L=\min \left[\left(\gamma^{2}+\lambda\right) \operatorname{Var}(Y)+\delta^{2} \operatorname{Var}(e)+2 \gamma^{\prime} \delta^{\prime} \operatorname{Cov}(Y e)\right]
$$

Esta equação é análoga a dizer que a autoridade monetária minimiza um soma ponderada de da variância de $(Y+E)^{6}$. Isto é, especificando a inflação da forma como foi feito implica que o objetivo da autoridade monetária é minimizar a volatilidade somada de produto e câmbio. Este resultado demonstra que, ao se fazer uma pequena alteração no modelo de Mundell-Fleming, incluindo a inflação como objetivo da autoridade monetária e o repasse cambial para preços, o chamado "fear of floating", aqui representado pelo termo $\delta^{2}$, sai como resultado do comportamento da autoridade monetária, em linha com a evidência empírica largamente discutida pela literatura.

A próxima subseção apresentará alguns experimentos numéricos conduzidos a partir deste Modelo Agregado para tornar mais concreta algumas de suas intuições.

\subsection{Experimentos}

Seguindo Blanchard (2016), os valores dos parâmetros foram definidos menos preocupados com sua cardinalidade e mais interessados em fazer análises comparativas quando se variam seus tamanhos relativos e quando são incluídos controles de capital. Nesse sentido, para o cenário base tomaremos $a=b=c^{*}=0,5, d=\gamma=1, c=0,25$ um valor arbitrário mas menor do que $c^{*}$, pensando que o país emergente possui os canais de transmissão da política monetária mais obstruídos, isto é, uma menor elasticidade juros da demanda. $\delta=0,15$, condizente com uma proporção de importados no consumo doméstico de $15 \%, g=0,3$, seguindo a hipótese de Rey (2015) de que a taxa de juros estadunidense explica cerca de um terço das variações da percepção de risco ( e assumindo que o impacto do risco no câmbio é de 1 para 1). Assumindo inicialmente que $\lambda=1, f=0.3$ tem-se que, para esta configuração de parâmetros $\Gamma_{R}=-0.2532$ e $\Gamma_{E}=-0.6163$. Este cenário será o modelo base.

Para a realização dos experimentos, supõe-se que $R^{*}, G$ e $G^{*}$ seguem processos autorregressivos de ordem 1 e coeficiente de correlação $\rho=0.9$, tal que:

$$
\begin{aligned}
R^{*} & =\rho R_{t-1}^{*}+v_{R^{*}} \\
G & =\rho G_{t-1}+v_{G} \\
G^{*} & =\rho G_{t-1}+v_{G^{*}}
\end{aligned}
$$

Em que $v_{R^{*}}, v_{G}, v_{G^{*}}$, são choques aleatórios e independentes de média zero e desvio padrão tal que 1 desvio padrão represente um choque de $1 \%$ na taxa anual (o modelo é estimado considerando que

${ }^{6}$ Para registrar, sendo $\mathrm{j}, \mathrm{k}$ quaisquer variáveis correlacionadas têm-se que $\operatorname{Var}(j+k)=\operatorname{Var}(j)+$ $\operatorname{Var}(k)+2 \operatorname{Cov}(j, k)$. 
cada intervalo de tempo equivale a um trimestre). Além disso, definimos o desvio padrão do choque de produtividade, $v$, e do choque de prêmio de risco, $\chi$, em $1 \%$ no trimestre.

A Figura 1 mostra as respostas deste modelo base a um choque de $1 \%$ na taxa de juros externa. Podemos observar que, tal qual o esperado, diante de uma elevação dos juros externos, há uma redução do produto externo e uma desvalorização da moeda doméstica. O efeito preço do câmbio é, como modelado, maior do que a redução da demanda externa, o que melhora as transações correntes. Porém, com o repasse cambial para a inflação, em resposta a um aumento de preços originados com a desvalorização cambial, a autoridade monetária deve subir a taxa de juros, o que eleva o juros real e deprime a economia doméstica, que também sofre com o aumento da restrição financeira sobre as empresas, dado que $f>0$.

Figura 1 - Modelo Base: Choque de 1\% Taxa de Juros Externa
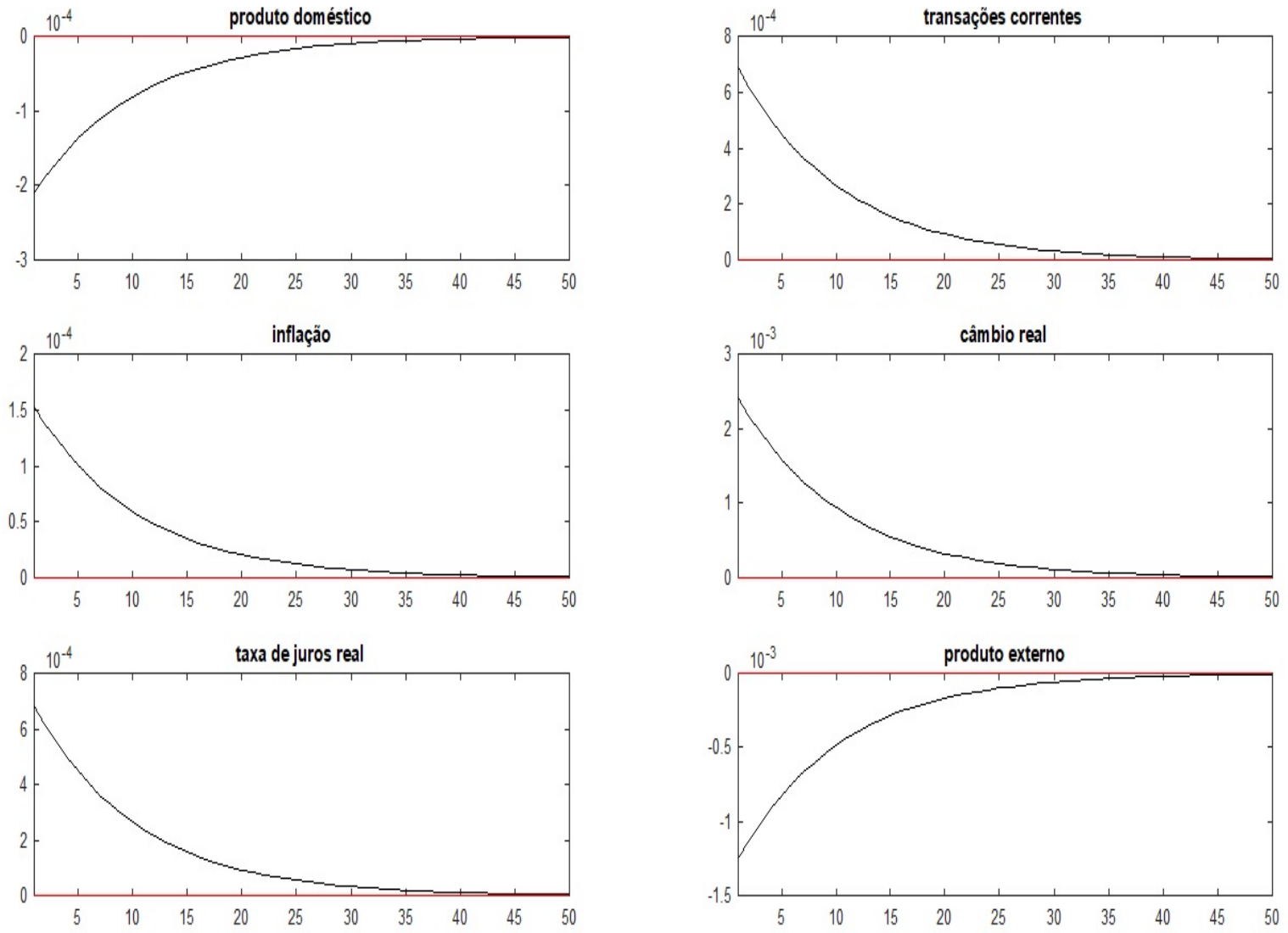

Agora serão analisadas configurações alternativas dos parâmetros. A Figura 2 e Figura 3 mostram a resposta da economia a um choque de juros externo comparando o cenário base, linha preta, com parametrizações alternativas da intensidade dos financial spillovers, linha vermelha tracejada. Na Figura 2 observamos o que acontece quando não há consequência financeiras de uma alteração do câmbio. Como era esperado, há uma queda menor do produto doméstico. O elemento não tão intuitivo é a desvalorização também menos acentuada do câmbio, o que implica uma menor inflação decorrente do choque externo. O motivo é um aumento significativamente maior da taxa de juros doméstica pela autoridade monetária: diante de um choque externo que não impacta negativamente o produto, há espaço para um aumento imediato e mais rigoroso na taxa de juros doméstica, reduzindo a desvalorização, diminuindo o impacto inflacionário e garantindo uma convergência mais veloz de volta ao equilíbrio.

Já a Figura 3 exibe o cenário oposto, aquele no qual $f=0.6>b$; este valor foi escolhido de tal 
modo que $f$ não é suficientemente grande para inverter a hipótese de que $\Gamma_{R}<0$. Neste caso, elevam-se as volatilidades do produto, do câmbio e da inflação diante de um choque externo. O ajuste é mais lento, pois a queda acentuada no produto acirra o trade-off da autoridade monetária ainda mais $\operatorname{com} \lambda=1^{7}$. Dessa forma, fica evidente que os financial spillovers representam uma fonte adicional de instabilidade para as economias emergentes. Não considerá-los em um modelo de economia aberta, como é comum, pode significar sério viés nos resultados obtidos, uma vez que a literatura empírica assegura sua existência.

Figura 2 - Comparação $f=0 \times f=0.3$ : Choque de $1 \%$ Taxa de Juros Externa
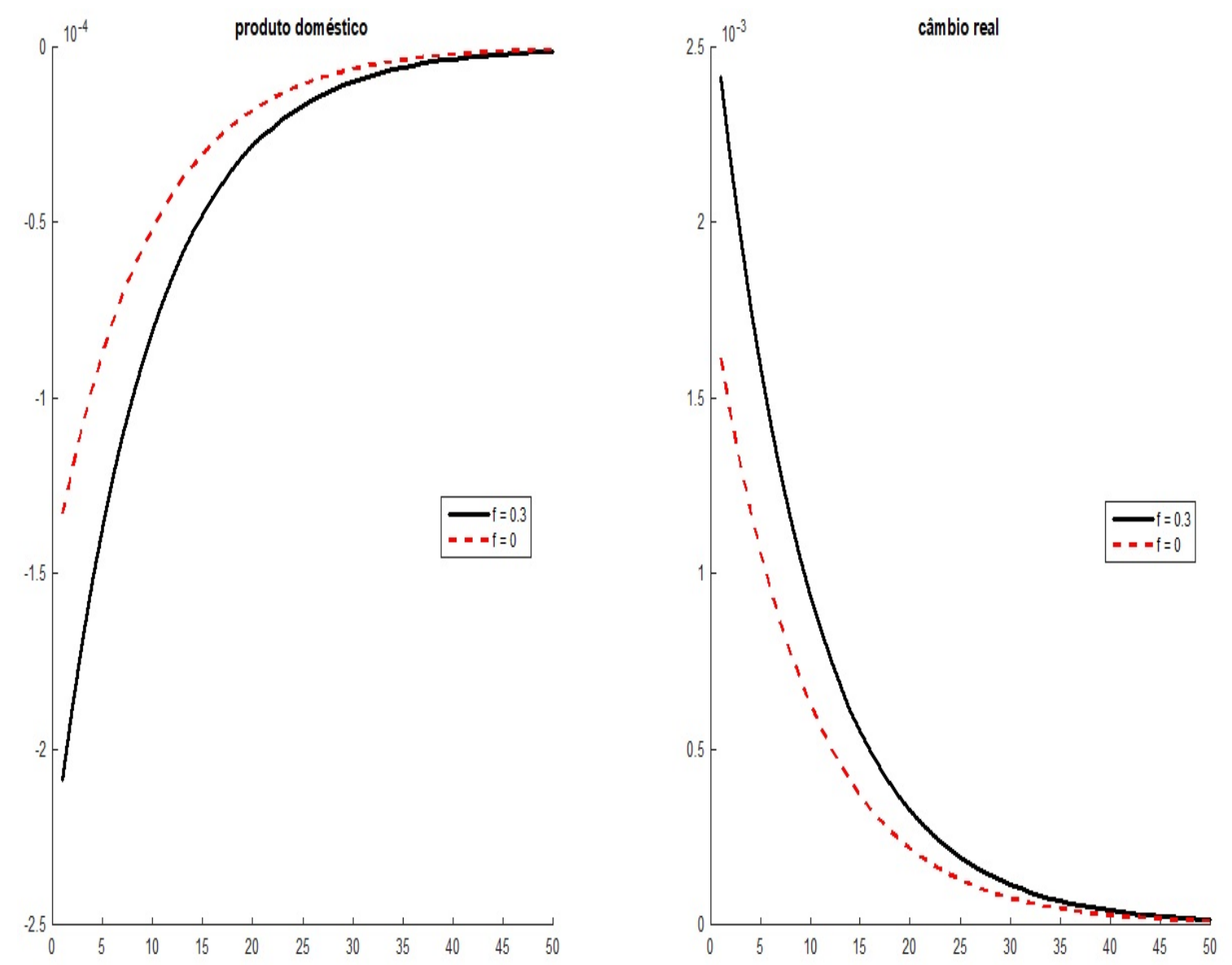

${ }^{7}$ Apenas para efeito de comparação, foram feitas simulações com $\lambda=1$, modelo base, e $\lambda=0.5$. Ao pesar menos desvios do produto, a autoridade monetária aceita elevar a taxa de juros em um patamar superior ao modelo base, o que gera uma maior queda do produto e uma leve atenuação na desvalorização cambial. O tempo de convergência nos dois casos é bastante próximo. Ou seja, neste modelo específico, a consideração que a política monetária tem com desvios do produto afeta pouco sua capacidade de reagir a choques externos, não piorando a velocidade do ajuste e atenuando a queda do produto. 
Figura 3 - Comparação $f=0.3 \times f=0.6$ : Choque de $1 \%$ Taxa de Juros Externa
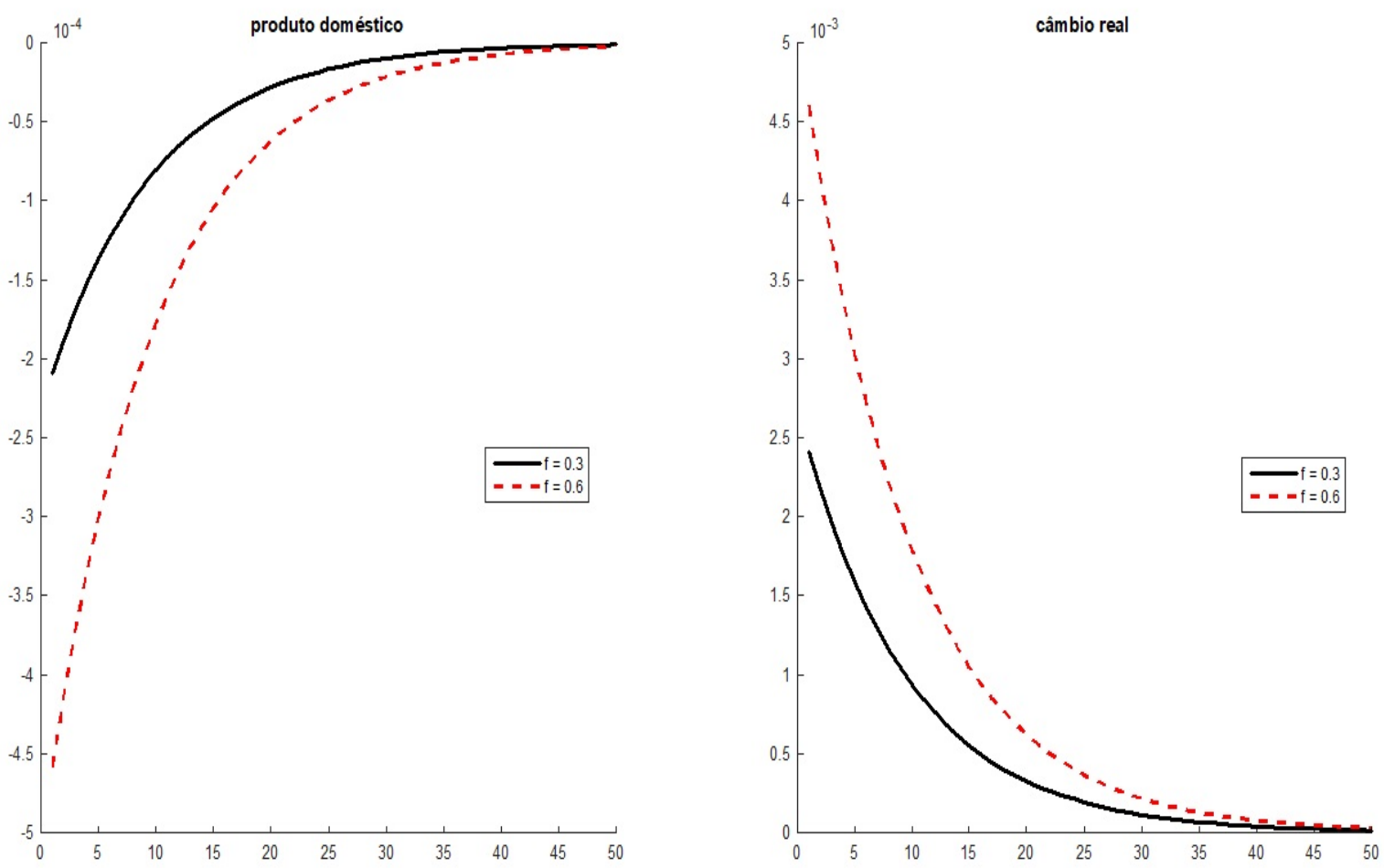

Outro teste válido é em relação à existência do ciclo financeiro global, o $g$ do nosso modelo. A figura Figura 5 mostra que, quando $g=0$, linha vermelha, diminuem as oscilações da economia frente a um choque de juros externo, ainda que de forma modesta. Este fato também reforça a importância de se incluir este efeito no modelo, uma vez que acarreta complicações adicionais para o exercício da política monetária. 
Figura 4 - Comparação $g=0$ x $g=0.3$ : Choque de 1\% Taxa de Juros Externa
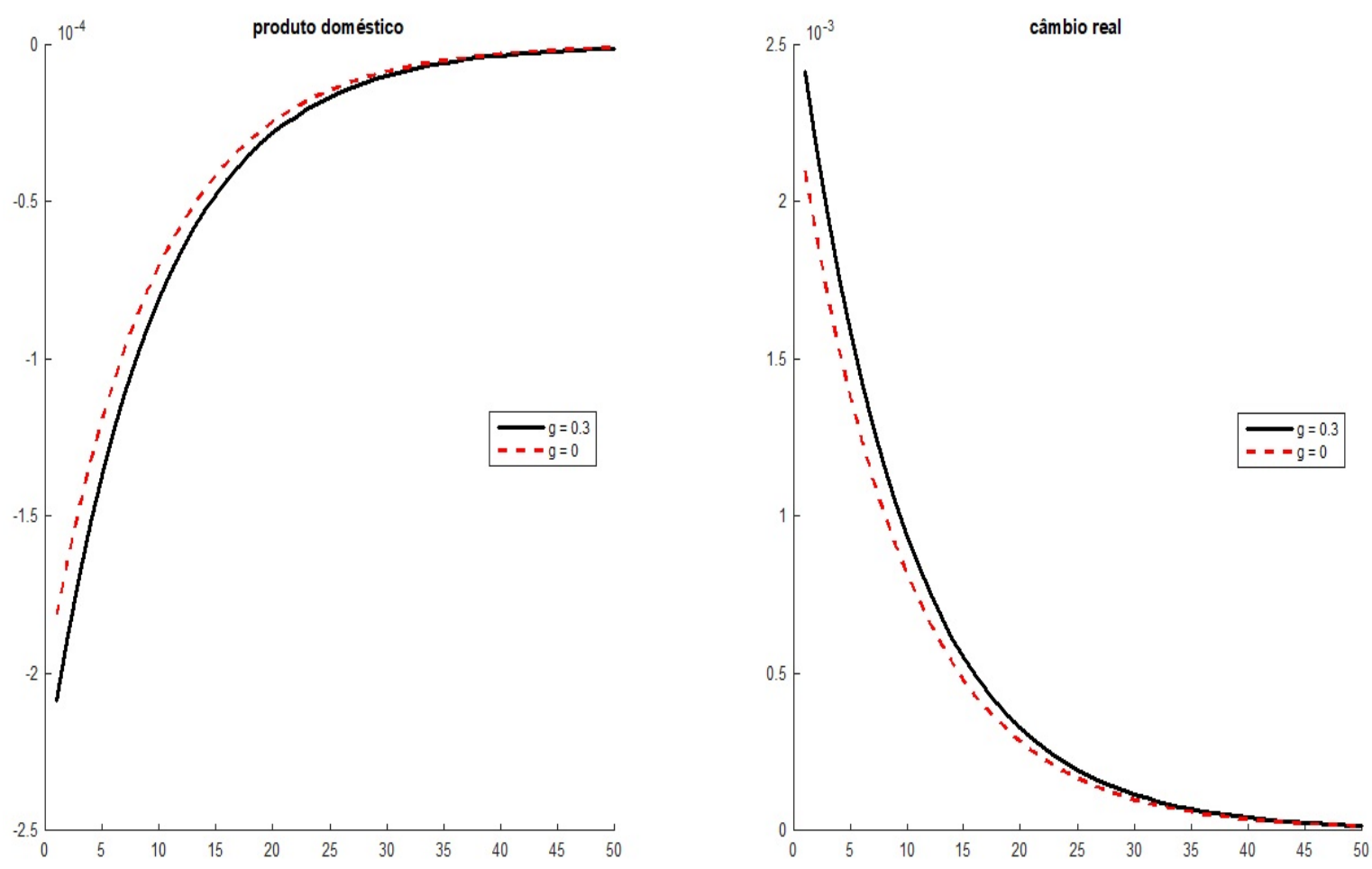

\subsubsection{Controle de Capitais}

Diante da evidente dificuldade que a autoridade monetária enfrenta quando a economia é atingida por um choque de juros externo, será testada se a adoção de medidas como controle de capitais podem atenuar o sacrifício exigido para que se retorne ao equilíbrio de estado estacionário. Seguiremos a proposta de política de Blanchard (2016) ao modelar o controle de capitais como uma tarifa sobre cada unidade de capital que ingressa no país, à semelhança do que foi feito pelo Brasil. A intuição é tornar menos dilatado o diferencial de juros. Tal que:

$$
\begin{aligned}
E & =d\left(R^{*}-(R-\tau)\right)-d \pi+g R^{*}+\chi \\
\tau & =-\omega_{\tau}(E) \\
G & =\rho G_{t-1}+\tau+v_{G}
\end{aligned}
$$

Diferentemente de Blanchard (2016) que determina uma forma funcional para $\tau$ de tal forma que ele sempre anule os efeitos de um aumento de juros externo; para o valor estabelecido de $\omega_{\tau}=0.1 \mathrm{a}$ política é, além de cíclica, mais modesta em seu potencial acomodacionista. No caso aqui analisado, a tarifa $\tau$ sobe em $0.1 \%$ a cada ponto percentual de oscilação de $\mathrm{E}$ em relação ao seu valor de equilíbrio, 0 . Quando o câmbio começa a se apreciar, $\tau$ se torna positivo e funciona como uma tarifa cobrada a cada capital que entra no país. Caso o câmbio deprecie, $\tau$ se torna negativo, subsidiando a entrada de novos capitais, atenuando dessa forma as oscilações provocadas por choques externos. A equação (25) apenas nos garante o orçamento equilibrado do governo. A cada real arrecadado com a tarifa aumenta-se na mesma proporção o gasto autônomo via consumo do governo.

Poderíamos definir a tarifa como função da variação do juros externo, o que gera resultado semelhante, ou do câmbio nominal, o que gera resultados muito equivalentes a este. A escolha pelo câmbio 
real em oposição ao juros externo é o fato de ser uma variável sobre a qual a política monetária pode interferir e portanto, pode ter uma "meta"para ela. Em relação ao câmbio nominal, dada a equivalência dos resultados, é para manter a consistência do modelo ao redor das variáveis reais. A Figura 5 mostra a economia após um choque de juros externo no cenário em que não há controle de capitais, linha preta, e no caso em que estes controles tem a forma descrita acima, linha vermelha.

Figura 5 - Comparação $\omega_{\text {tau }}=0 \mathrm{x} \omega_{\text {tau }}=0.1$ : Choque de $1 \%$ Taxa de Juros Externa
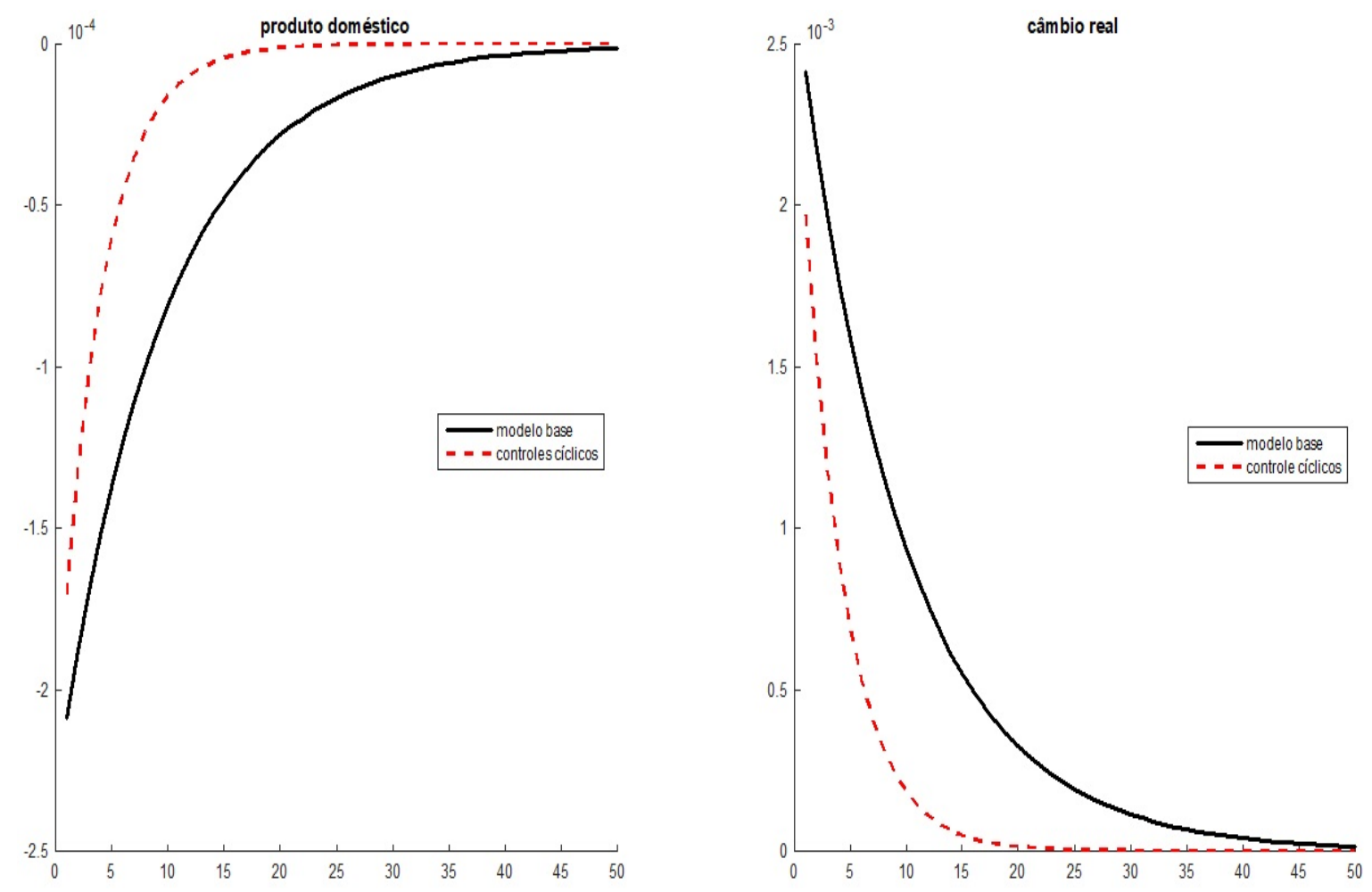

Observamos que, como era esperado, a inclusão de controles de capital facilita a tarefa da autoridade monetária. A convergência de volta para o equilíbrio do produto e do câmbio é mais rápida, além do fato de que a queda do produto e desvalorização cambial são amortecidas pela inclusão da política. O problema de se avaliar a adoção dessa regra em um modelo como este é que o elemento central pró integração financeira de se obter um alívio à restrição de crédito não aparece no modelo, diminuindo os trade-offs associados a adoção dos controles de capital.

Conforme $f$ aumenta, o efeito da adoção da política também se torna maior, mostrando que a existência das friç̧ões financeiras motivam, por si só, um olhar mais atento. A Tabela 1 indica a variação da média incondicional da função perda em uma aproximação de segunda ordem (para captar a variância) nos casos com e sem controle de capitais, para diferentes valores de $f$. Um $\Delta L$ negativo significa que a média estimada da função perda é menor com controle de capitais. Isto é, mais autonomia de política monetária, medida como a capacidade de se obter valores mais próximos do zero ao longo de toda a trajetória da economia. O valor deste ganho em si é irrelevante, uma vez que $L$ diz respeito a uma variável ordinal, logo, o interessante destes resultados é observar que conforme $f$ aumenta, o ganho associado ao controle de capitais cresce. De tal modo que, se para $f=0$ o ganho é praticamente nulo, ele aumenta cerca de $30 X$ quando $f=0.6$. 


\begin{tabular}{|c|c|}
\hline Valores de $f$ & $\Delta L$ \\
\hline$f=0$ & $-0.0023 \%$ \\
\hline$f=0.3$ & $-0.0108 \%$ \\
\hline$f=0.6$ & $-0.0694 \%$ \\
\hline
\end{tabular}

Tabela 1 - Efeito de controles de capital para diferentes níveis de financial spillovers

\subsection{Conclusão}

A partir deste esforço, observa-se que autoridades monetárias que minimizam desvios da inflação e do produto, em um cenário em que há repasse cambial para os preços, estão minimizando a variância da soma ponderada entre produto e câmbio, condizente com a evidência empírica do "fear of floating. Além disso, sob uma determinada configuração de parâmetros e neste arcabouço específico, o trade-off entre inflação e produto se manifesta para a autoridade monetária como uma relação inversa entre desvalorização cambial e produto. O modelo evidencia que a existência de friç̧ões financeiras causadas por oscilações cambiais ampliam as dificuldades para política monetária acomodar um choque externo, levando a crer que a não consideração dos financial spillovers pode significar a omissão de uma variável relevante nas análises convencionais de economia aberta. A existência do ciclo financeiro global também proporciona maior volatilidade da economia doméstica diante de alterações internacionais.

Neste contexto, a adoção de um instrumento adicional de política monetária como controle de capital minimiza o custo associado à acomodação de um desequilíbrio externo provocado por um choque na taxa de juros internacional, reduzindo em três vezes, em relação ao cenário base, o tempo necessário para que a economia retorne ao equilíbrio pós perturbação. Além disso, verificamos que quanto mais fortes são os financial spillovers, mais benéfica é a adoção de controle de capitais do ponto de vista da autoridade monetária.

Dada a relevância da dimensão financeira, uma das grandes limitações deste arcabouço é justamente não modelar suas origens e racionalidade, correndo o risco, inclusive, de subestimar a importância do financiamento externo para a economia doméstica. Evidentemente, diante do ferramental utilizado no Modelo Agregado e de sua intencional simplicidade não se esperaria uma especificação mais densa. Seu objetivo é apresentar intuições e motivar a análise mais minuciosa das fricções financeiras realizada em sequência. De todo modo, este modelo evidencia que, mesmo com um instrumental bastante sintético, resultados importantes aparecem e questionam a validade de algumas das convenções da literatura. 


\section{Modelo Novo Keynesiano}

\subsection{Introdução}

Políticas macroeconômicas alternativas que visem ampliar a autonomia da autoridade monetária ganharam destaque no debate econômico do pós-crise de 2008 como discutido pelo Capítulo 1. Do ponto de vista teórico, medidas macroprudenciais podem ser benéficas em um ambiente em que há um collateral constraint para o endividamento externo. Neste sentido, seguem, por exemplo, Mendoza (2010). Em um modelo mais recente que parte desta mesma intuição, Davis e Presno (2017) encontram resultados positivos para medidas como controles de capital. Por outro caminho, Farhi e Werning (2014) mostram que controles de capital podem ser efetivos em suavizar os impactos de grandes fluxos financeiros nos termos de troca, ajudando a política monetária a estabilizar o ciclo de negócios. Farhi e Werning (2016) extendem este ferramental para um contexto amplo de rigidezes nominais e reafirmam o benefício associado a este tipo de política. A formalização conduzida neste capítulo segue principalmente a literatura que avaliou políticas macroprudenciais em economias abertas na presença de friç̧ões financeiras em um contexto em que há espaço para a política monetária (parte significativa dos modelos de collateral constraint são modelos reais), especialmente Aoki, Benigno e Kiyotaki (2016) e Landi (2017). Em ambos, O endividamento externo por intermediadores financeiros é o que enseja uma possível preferência por políticas alternativas.

O modelo desenvolvido neste capítulo parte de um arcabouço de economia aberta convencional, na linha por exemplo de Obstfeld e Rogoff (1995), Gali e Monacelli (2005), Uribe e Schmitt-Grohé (2017), e o combina com a maneira de modelar o sistema financeiro/bancário proposta por Gertler e Karadi (2011) e Gertler e Kiyotaki (2015).

O Modelo Novo Keynesiano é uma adaptação daquele desenvolvido por Aoki, Benigno e Kiyotaki (2016) para parâmetros mais próximos à realidade brasileira. As alterações feitas aqui acontecem em três dimensões. A primeira em relação à construção do ambiente externo e consequentemente do tipo de choques aos quais estão sujeitos os bancos domésticos. Explicita-se uma relação para o prêmio de risco que é, tal qual sugerido pelo evidência empírica, dependente da taxa de juros dos EUA e da demanda global. Outra dimensão em que a análise deste capítulo descola do modelo que a inspira é na formatação do problema de agência ao qual os bancos estão sujeitos. Definimos que os bancos estão mais suscetíveis à desviar do comportamento honesto de maneira estritamente crescente em relação ao nível de endividamento externo. A terceira dimensão segue da motivação do experimento e implica em diferentes análises de políticas.

A formatação proposta neste capítulo busca compatibilizar as intuições do modelo anterior com mais estrutura analítica, permitindo conduzir experimentos que foquem na questão da autonomia da política monetária para valores mais próximos ao caso brasileiro. Notadamente, talvez sua maior contribuição seja especificar uma racionalidade para a existência dos financial spillovers que como visto anteriormente são a maior fonte de volatilidade na economia descrita pelo Modelo Agregado. A não internalização por parte dos agentes financeiros das externalidades associadas ao financiamento em moeda estrangeira, abre espaço para uma melhora alocativa via controles de capital, ou medidas macroprudenciais, tal como sugerido por Rey (2015). 


\subsection{O Modelo Novo Keynesiano}

O objetivo deste modelo é analisar os desafios que uma estrutura econômica pautada pela existência do "pecado original"e de descasamentos entre dívidas e ativos em moeda estrangeira impõem para a condução da política monetária de maneira independente. A formatação desenvolvida incorpora o caráter inflacionário decorrente de uma desvalorização cambial observado na literatura empírica. Um diferencial importante é a especificação de uma relação entre taxa de juros, demanda internacional e prêmio de risco. Com isso, se amplia a possibilidade de experimentos e a compreensão dos mecanismos de transmissão de choques internacionais para a economia doméstica, favorecendo a análise sobre a questão da autonomia de política monetária.

A Figura 6 mostra de maneira esquemática os fluxos comerciais e financeiros da economia descrita pelo modelo apresentado nas próximas subseções. Resumidamente, há um setor doméstico, composto por firmas, famílias e bancos e um setor externo que é fonte de demanda para as exportações, bens importados pela economia doméstica e recursos financeiros. Domesticamente, as famílias detém a posse das firmas e se dividem entre trabalhadores e banqueiros. Os bancos financiam investimento em capital (via compra de açõs/equity) por meio de depósitos bancários das famílias, endividamento externo ou usando seu patrimônio líquido/capital próprio. Cada um destes agentes será descrito em sequência.

Figura 6 - Esquema ilustrativo do Modelo Novo Keynesiano

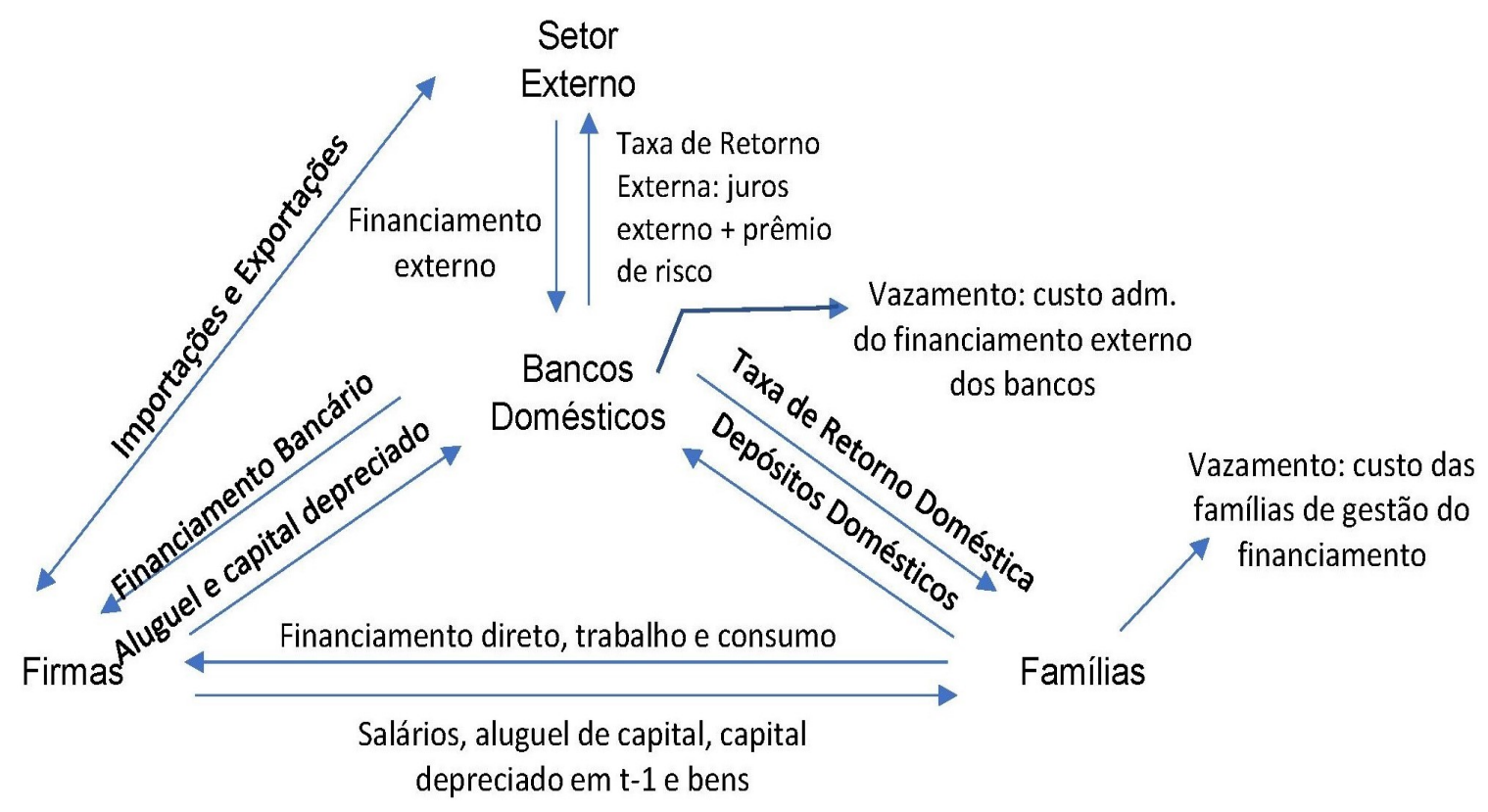

\subsubsection{Firmas}

Seguindo Aoki, Benigno e Kiyotaki (2016), e como é convencional neste tipo de modelo, a produção é realizada à la Dixit-Stilgitz (DIXIT; STIGLITZ, 1977). Isto é, a produção dos bens finais se dá a partir de um contínuo de bens intermediários $y_{i t}, i \in[0,1]$, sob concorrência perfeita e de acordo com a seguinte 
agregação:

$$
Y_{t}=\left(\int_{0}^{1} y_{i t}^{\frac{\eta-1}{\eta}} d i\right)^{\frac{\eta}{\eta-1}}
$$

em que a tecnologia segue retornos constantes de escala e $\eta>1$ é a elasticidade da demanda por bens intermediários. O preço de cada bem intermediário é $p_{i t}$ de tal forma que $P_{t}=\left(\int_{0}^{1} p_{i t}^{1-\eta} d i\right)^{\frac{1}{1-\eta}}$ é o índice de preços agregado da economia.Para determinados $p_{i t}$ e $P_{t}$, os produtores dos bens intermediários que operam sobre concorrência monopolística são confrontados com a seguinte curva de demanda, condizente com a maximização das firmas produtoras do bem final:

$$
y_{i t}=\left(\frac{p_{i t}}{P t}\right)^{-\eta} Y_{t}
$$

Ou seja, quanto menor $p_{i t}$ em relação a $P_{t}$, maior a demanda pelo bem intermediário $y_{i} t$. Por sua vez, cada bem intermediário é produzido de acordo com a seguinte função de produção de retornos constantes à escala:

$$
y_{i t}=Z_{t}\left(\frac{k_{i t}}{\alpha_{k}}\right)^{\alpha_{k}}\left(\frac{m_{i t}}{\alpha_{k}}\right)^{\alpha_{m}}\left(\frac{l_{i t}}{1-\alpha_{k}-\alpha_{m}}\right)^{1-\alpha_{k}-\alpha_{m}}
$$

onde $Z_{t}$ é um choque agregado de produtividade e os insumos são capital, $k_{i t}$, bens importados, $m_{i t}$, e horas de trabalho, $l_{i t}$. Sendo $\alpha_{k}, \alpha_{m}$ e $1-\alpha_{k}-\alpha_{m} \in[0,1]$ as participações de cada insumo na produção (cost share). Sendo $S_{t}, \epsilon_{t}$ e $w_{t}$ respectivamente, em termos do bem de consumo, o custo de aluguel do capital, o preço do bem importado (que neste caso, como só há importação deste bem coincide com a taxa de câmbio real) e o salário. A minimização dos custos determina a seguinte relação para o custo marginal, $m c_{t}$ :

$$
m c_{t}=\frac{1}{Z_{t}} S_{t}^{\alpha_{k}} \epsilon_{t}^{\alpha_{m}} w_{t}^{1-\alpha_{k}-\alpha_{m}}
$$

As firmas que operam sobre concorrência monopolística estão sujeitas a custos de ajustamento do tipo Rotemberg (1982), tal que a maximização do lucro intertemporal, que determina $\left(p_{i t}, y_{i t}\right)$, se torna:

$$
\mathbb{E}_{0}\left\{\sum_{t=0}^{\infty} \Lambda_{0, t}\left[\left(\frac{p_{i t}}{P_{t}}-m c_{t}\right) y_{i t}-\frac{\kappa}{2}\left(\frac{p_{i t}}{p_{i t-1}}-1\right)^{2} Y_{t}\right]\right\}
$$

em que $\Lambda_{0, t}$ é o fator de desconto intertemporal do agente representativo que será definido adiante. O termo quadrático reflete o custo de ajustamento. Embora com a formatação de Rotemberg (1982), $\kappa$ será escolhido tal que chegue-se a uma expressão equivalente a ajuste de preços à la Calvo $(1983)^{1}$. Avaliando no equilíbrio simétrico a condição de primeira ordem do problema da firma em relação a $p_{i t}$ chega-se a:

$$
\left(\pi_{t}-1\right) \pi=\frac{1}{\kappa}\left(\eta m c_{t}+1-\eta\right)+\mathbb{E}_{t}\left[\Lambda_{t, t+1} \frac{Y_{t+1}}{Y_{t}} \pi_{t+1}\left(\pi_{t+1}-1\right)\right]
$$

\footnotetext{
${ }^{1}$ Isto é, em um cenário em que a mudança de preços se da segundo um processo de Bernoulli em a fração daqueles que ajustatam preços em t é $(1-\omega)$, temos que para $\kappa=\frac{(\eta-1) \omega}{(1-\omega)(1-\beta \omega}$, as expressões são equivalentes e $\kappa$ será calibrado a partir de valores para omega.
} 
Em que $\pi=\frac{P_{t}}{P_{t-1}}$ é um mais a taxa de inflação. Aoki, Benigno e Kiyotaki (2016) definem o equilíbrio ao redor do estado estacionário não-inflacionário em que $\pi=\frac{\eta}{\eta-1} m c=1$, o que gera a usual Curva de Phillips Novo Keynesiana log-linearizada:

$$
\hat{\pi}_{t}=\frac{\eta-1}{\kappa} \hat{m} c+\beta \mathbb{E}_{t}\left(\pi_{t+1}\right)
$$

em que variáveis do tipo $\hat{a}=\frac{\left(a_{t}-a\right)}{a}$ são desvios do valor de estado estacionário. No equilíbrio simétrico e agregando os fatores de produção tal que $K_{t-1}=\int_{0}^{1} k_{i t} d i, M_{t}=\int_{0}^{1} m_{i t} d i, L_{t}=\int_{0}^{1} l_{i t} d i$, temos que o produto agregado pode ser descrito como $^{2}$ :

$$
Y_{t}=Z_{t}\left(\frac{K_{t-1}}{\alpha_{k}}\right)^{\alpha_{k}}\left(\frac{M_{t}}{\alpha_{k}}\right)^{\alpha_{m}}\left(\frac{L_{t}}{1-\alpha_{k}-\alpha_{m}}\right)^{1-\alpha_{k}-\alpha_{m}}
$$

Desta forma, a minimização de custos garante as tradicionais relações entre custo e produtividade marginal dos fatores:

$$
\begin{aligned}
\frac{\epsilon_{t} M_{t}}{S_{t} K_{t-1}} & =\frac{\alpha_{m}}{\alpha_{k}} \\
\frac{w_{t} L_{t}}{S_{t} K_{t-1}} & =\frac{1-\alpha_{k}-\alpha_{m}}{\alpha_{k}}
\end{aligned}
$$

As firmas também são responsáveis pela acumulação de capital que acontece por meio do investimento. O investimento por sua vez é produzido por meio de uma tecnologia da qual decorre o seguinte custo total $\left[1+\Phi\left(\frac{I_{t}}{I}\right)\right] I_{t}$, tal que, como é convencional nestes modelos, há um custo adicional de prover investimento a um nível distinto daquele do estado estacionário $I$. Em particular, definimos $\Phi\left(\frac{I_{t}}{I}\right)=\frac{\kappa_{I}}{2}\left(\frac{I_{t}}{I}-1\right)^{2}$, tal que $\Phi(1)=\Phi^{\prime}(1)=0$ e $\Phi "\left(\frac{I_{t}}{I}\right)>0$. Rearranjando a expressão $\Phi\left(\frac{I_{t}}{I}\right)$ ao redor do equilíbrio de estado estacionário do investimento temos que: $\Phi\left(\frac{I_{t}}{I}\right)=\frac{\kappa_{I}}{2} \hat{I}_{t}^{2}$.

A acumulação de capital é dada por:

$$
K_{t}=I_{t}+\lambda K_{t-1}
$$

Finalmente, as firmas são responsáveis também pela exportação da economia, $E x_{t}$, que depende negativamente do preço doméstico, $P_{t}$ e positivamente da demanda externa $Y_{t}^{*}$, do preço internacional $P_{t}^{*}$ e da taxa de câmbio nominal $e_{t}$. Sendo o câmbio real, $\epsilon_{t} \equiv\left(\frac{e_{t} P_{t}^{*}}{P_{t}}\right)$,

$$
E x_{t}=\left(\frac{e_{t} P_{t}^{*}}{P_{t}}\right)^{\varphi} Y_{t}^{*}=\epsilon^{\varphi} Y_{t}^{*}
$$

sendo $\varphi$ a elasticidade preço da demanda exterior, que assumimos constante. Além disso, tal qual no Modelo Agregado, não há inflação externa, ou seja, $P_{t}^{*}=P^{*}=1$.

\subsubsection{Famílias}

As famílias são proprietárias das firmas. Além disso, para modelar o sistema financeiro seguindo Gertler e Karadi (2011) e Gertler e Kiyotaki (2015), assumimos que o agente representativo é um contínuo

\footnotetext{
${ }^{2}$ Entende-se $K t-1$ como o estoque de capital no início do período $t$, acumulado até $t-1$, que está disponível para a produção
} 
que se divide entre banqueiros e trabalhadores, com o tamanho da população normalizado em um. Esta fração é constante ao longo do tempo. Conforme os banqueiros deixam de existir (se aposentam, morrem) eles repassam para a família o seu patrimônio líquido e são substituídos por novos trabalhadores que se tornam banqueiros. A cada período um banqueiro se aposenta com probabilidade $(1-\sigma)$ e em seu lugar um novo banqueiro começa a operar com uma fração $\xi$ da remuneração total dos ativos da economia daquele período. O funcionamento dos bancos será melhor descrito à frente. Por hora, vale ressaltar que é preciso que os banqueiros se aposentem para que não acumulem patrimônio indefinidamente, e a sua aposentadoria representa o pagamento de dividendos, ou bônus, para as famílias, representando a parcela da renda que advém do setor financeiro ${ }^{3}$.

Como o objetivo do trabalho não é compreender fricções de crédito entre o setor financeiro e o setor produtivo, mas entre o setor financeiro e seus financiadores externos, assumimos que os bancos conseguem repassar recursos para as firmas de maneira direta por meio da compra de ações, propriedade de capital (equity). Os trabalhadores também podem investir diretamente em ações, mas pagam um custo operacional para conseguir fazê-lo, uma taxa administrativa que é definida como $\chi^{h}\left(K_{t}^{h}, K_{t}\right)=\frac{\kappa_{h}}{2}\left(\frac{K_{t}^{h}}{K_{t}}\right)^{2} K_{t}$, em que $K_{t}^{h}$ é parcela do estoque de capital sob propriedade das famílias. O custo administrativo é crescente na razão do capital em posse dos trabalhadores sobre o estoque de capital total, em que $\kappa_{h}$ é um parâmetro positivo que representa a desvantagem dos trabalhadores em relação aos banqueiros no investimento em ações. Tanto trabalhadores como banqueiros, entretanto, recebem a mesma remuneração em relação ao investimento em capital, a saber, a taxa de aluguel do capital daquele período, $S_{t}$, mais o valor de revenda daquela propriedade em termos de bens, $Q_{t}$, menos a depreciação que ocorreu ao longo do uso produtivo do capital. Além disso, os trabalhadores também podem poupar na forma de depósitos bancários, $D_{t}^{n}$, que são contratos de curto prazo, não contingentes e cujo retorno nominal é $\left(1+i_{t}\right) D_{t}^{n}$, onde $i_{t}$ é a taxa de juros nominal que incide sobre os depósitos. Os trabalhadores não têm acesso ao mercado internacional de crédito. Tanto porque talvez não tenham a expertise necessária para isso, ou porque a taxa de juros doméstica é sempre maior do que a externa e os trabalhadores não estão sujeitos a riscos cambiais significativos.

Ao entender as diferentes formas de poupança dos trabalhadores, podemos compreender a racionalidade para o custo administrativo para que acessem o mercado de capitias. Há uma razão de "realismo"na medida em que parece ser compreensível que trabalhadores tenham menos acesso à informação e menos escala de operação para investir com a mesma eficiência que os bancos no mercado acionário. Além disso, como o spread bancário é sempre positivo, isto é, a taxa na qual os bancos remuneram os depósitos à vista é sempre menor do que a remuneração do mercado de capital e como tanto trabalhadores quando banqueiros estão sujeitos aos mesmos riscos ao investir em ações, o setor financeiro poderia se tornar obsoleto na ausência de $\chi^{h}\left(K_{t}^{h}, K_{t}\right)>0$.

O agente representativo escolhe seu consumo, a oferta de trabalho, e a poupança em estoque de capital e depósitos bancários segundo o seguinte problema de otimização:

\footnotetext{
${ }^{3}$ Para reforçar este ponto, o agente representativo deve conter em sua unicidade a diversidade da economia como um todo. Esta é a razão da esquizofrenia aparente em ser apenas um, divido entre trabalhador, banqueiro, dono das firmas. Este fato, entretanto, não é, ao meu ver, o fator limitante do modelo. Há diversos caminhos, em desenvolvimento constante na literatura, de relaxar esta hipótese e assumir agentes heterogêneos. Seguramente, isso representa uma melhora técnica e analítica relevante e que vão além, entretanto, do objetivo deste trabalho.
} 


$$
\begin{gathered}
\max _{C_{t}, L_{t}, K_{t}^{h}, D_{t}} \mathbb{E}_{0}\left[\sum_{t=0}^{\infty} \beta^{t} \ln \left(C_{t}-\frac{\zeta_{0}}{1+\zeta} L_{t}^{1+\zeta}\right)\right] \\
s . a \\
C_{t}+Q_{t} K_{t}^{h}+\chi^{h}\left(K_{t}^{h}, K_{t}\right)+D_{t}=w_{t} L_{t}+\Pi_{t}+\left(S_{t}+\lambda Q_{t}\right) K_{t-1}^{h}+R_{t} D_{t-1}
\end{gathered}
$$

A forma funcional escolhida, seguindo Aoki, Benigno e Kiyotaki (2016), é do tipo proposto por Greenwood, Hercowitz e Huffman (1988), ou seja, em que consumo e trabalho não são aditivamente separáveis. Isso implica que a derivada cruzada entre consumo e oferta de trabalho não é zero e, ao mesmo tempo, que não há efeito riqueza na oferta de trabalho permitindo captar melhor a pró-ciclicidade do trabalho formal nas economias periféricas. Adicionalmente, $0<\beta<1$ é a taxa de desconto intertemporal do agente representativo e $\zeta_{0}, \zeta$ são respectivamente o inverso da capacidade da oferta de trabalho e o inverso da elasticidade de Frisch. $D_{t} \equiv D_{t}^{n} / P_{t}$ são depósitos bancários em termos dos bens, $R_{t}=\frac{1+i_{t-1}}{\pi_{t}}$ é a taxa de juro real sobre os depósitos bancários de $t-1$ à $t$. Finalmente, П são os lucros remetidos às famílias pelas firmas produtoras dos bens intermediários, bens de capital e bancos. Como as firmas produtoras do bem final operam sobre concorrência perfeita, o lucro econômico é zero.

$$
\begin{aligned}
\Pi_{t}=\int_{0}^{1}[ & {\left[\left(\frac{p_{i t}}{P_{t}}-m c_{t}\right)-\frac{\kappa}{2}\left(\frac{p_{i t}}{p_{t-1}}-1\right)^{2} Y_{t}\right] d i+\left[Q_{t}-1-\Phi\left(\frac{I_{t}}{I}\right)\right] I_{t} } \\
& +(1-\sigma)\left[\left(S_{t}+\Lambda Q_{t}\right) K_{t-1}^{b}-R_{t} D_{t-1}-\epsilon_{t} R_{t}^{*} D_{t-1}\right]-\xi\left(S_{t}+\lambda Q_{t}\right) K_{t-1}
\end{aligned}
$$

A primeira linha da expressão acima são os lucros das firmas e a segunda são os dividendos dos bancos que encerram atividades naquele momento menos os fundos iniciais dos novos bancos. Novamente, o funcionamento do sistema bancário será explicado adiante.

As condições de primeira ordem em relação ao trabalho e às diversas formas de poupança, incluindo investimento, garantem que:

$$
\begin{aligned}
& w_{t}=\zeta_{0} L_{t}^{\zeta} \\
& 1=\mathbb{E}_{t}\left(\Lambda_{t, t+1} \frac{Z_{t+1}+\lambda Q_{t+1}}{Q_{t}+\kappa_{h} \frac{K_{t}^{h}}{K_{t}}}\right), \Lambda_{t, \tau}=\beta^{\tau-t} \frac{C_{t}-\frac{\zeta_{0}}{1+\zeta} L_{t}^{1+\zeta}}{C_{\tau}-\frac{\zeta_{0}}{1+\zeta} L_{\tau}^{1+\zeta}} \\
& 1=\mathbb{E}_{t}\left(\Lambda_{t, t+1} R_{t+1}\right) \\
& Q_{t}=1+\Phi\left(\frac{I_{t}}{I}\right)+\left(\frac{I_{t}}{I}\right) \Phi^{\prime}\left(\frac{I_{t}}{I}\right)
\end{aligned}
$$

\subsubsection{Bancos}

O setor bancário, financeiro, é o elemento central deste modelo e é também onde se encontram as diferenças entre a formatação expressa nesta dissertação e aquela apresentada por Aoki, Benigno e Kiyotaki (2016). Cada elemento específico ao nosso modelo será comentado na ocasião conveniente. Os bancos da economia são, na verdade, intermediadores financeiros. Tal qual aos trabalhadores, porém de forma mais eficiente que estes, financiam o setor produtivo por meio de investimento direto em capital, sem fricções, e são os únicos agentes domésticos capazes de acessar o mercado de crédito internacional, no qual podem contrair dívidas, ou poupar, em moeda estrangeira. 
O fato de se endividarem em moeda estrangeira, sem proteção cambial e de maneira crescente em relação ao spread doméstico - a diferença entre a remuneração do investimento em capital e o pagamento de juros sobre os depósitos bancários - e na vantagem relativa do financiamento estrangeiro em relação ao nacional, abre espaço para a política monetária não convencional. Além disso, como mostraremos, a alavancagem dos bancos depende de seu patrimônio líquido, o que confere ao modelo uma característica de "acelerador financeiro"( financial accelerator) à la Bernanke, Gerlter e Gilchrist (1999). Ou seja, nos momentos em que as condições externas estão favoráveis e/ou o retorno do capital relativamente alto, os bancos agem pró-ciclicamente, alimentando o boom e se expondo ao risco cambial externo, via elevação do endividamento estrangeiro. Em um momento de choque internacional, uma elevação do juros externo, por exemplo, acompanhada de uma desvalorização cambial deteriora rapidamente o balanço dos bancos que reduzem de maneira drástica a intermediação financeira, derrubando o preço do capital, reduzindo o investimento agregado e colocando a economia em uma recessão duradoura num mecanismo do tipo debt-deflation (FISHER, 1933). De tal forma, que a intuição econômica para a melhora alocativa que se observa com a introdução de controles de capital, ou medidas macroprudenciais, deriva justamente da não internalização pelos bancos do risco agregado que geram para a economia ao se financiarem em moeda estrangeira, como sugere a evidência do "pecado original"e do descasamento monetário entre ativos e passivos.

Os banqueiros constituem o mesmo agente representativo que os trabalhadores e, antes de serem intermediadores financeiros, eram vendedores de força de trabalho. Ao se aposentarem, os donos dos bancos retomam suas atividades laborais, sendo substituídos na atividade bancária por novos trabalhadores. A hipótese de aposentadoria (saída, troca, morte) dos banqueiros deriva de uma necessidade matemática, amparada na lógica, de que, caso não se aposentassem nunca, os bancos poderiam acumular patrimônio líquido indefinidamente e desta forma escapar das restrições de financiamento definidas por seus balanços patrimoniais. De tal forma que, a cada período uma fração $(1-\sigma)$ dos banqueiros se aposenta e transfere para o agente representativo na forma de dividendos o patrimônio liquido acumulado neste período, e uma outra fração $\sigma$ segue operando. Ou seja, o objetivo do banco em um instante de tempo $t$, dado que ele segue sendo banqueiro neste período, é maximizar o valor presente do seu dividendo futuro definido por:

$$
V_{t}=\mathbb{E}_{t}\left[\sum_{j=1}^{\infty} \Lambda_{t, t+j} \sigma^{j-1}(1-\sigma) n_{t+j}\right]
$$

em que $\Lambda_{t, t+j}$ é o fator de desconto intertemporal do agente representativo e $n_{t+j}$ é o valor do patrimônio líquido acumulado no momento de sua aposentadoria.

Os instrumentos de política disponíveis para intervir na atividade bancária são uma taxa sobre o financiamento externo, $\tau_{t}^{d}$, e outra sobre a posse de ativos arriscados, $\tau_{t}^{K}$, contidos no balanço do banco naquele momento. Para garantir orçamento equilibrado do ponto de vista agregado, como em Gertler, Kiyotaki e Queralto (2012), o valor arrecado é retransferido aos bancos na forma de subsidio ao patrimônio líquido, $\tau_{t}^{N}$. Uma extensão que parece interessantes e simples seria avaliar o efeito de transferir os recursos arrecadados para os trabalhadores, via um bônus de consumo, ou para o setor de bens de capital. O problema destas alternativas, entretanto, é que as taxas se tornam subsídios a depender do período do ciclo, desta forma manter a arrecadação e o gasto sempre sobre o setor bancário diminui as distorções na economia e faz com que $\tau_{t}^{K}$ se assemelhe a um nível variável de requisitos de capital e $\tau_{t}^{d}$ possa ser entendido como restrições ao financiamento externo, ou custos adicionais variáveis de se acessar este mercado.

Seja $N_{t}$, o patrimônio líquido agregado dos bancos da economia, $K_{t}^{b}$ a posse de capital detida 
pelos bancos e $D_{t}^{*}$ o volume de dívidas denominadas em moeda estrangeira em $t$, temos:

$$
\tau_{t}^{N} N_{t}=\tau_{t}^{K} Q_{t} K_{t}^{b}+\tau_{t}^{d} \epsilon_{t} D_{t}^{*}
$$

Cada banco escolhe individualmente $d_{t}, d_{t}^{*}, k_{t}^{b}$ de tal forma a maximizar o valor presente esperado de seus dividendos. Como é tradicional neste tipo de modelo, endogeneizamos as fricções de crédito por meio de um problema de contrato, o que garante em equilíbrio um spread positivo entre remuneração dos depósitos domésticos e o retorno sobre a posse do capital. Não fosse este problema de agência que limita a alavancagem do setor, os bancos tomariam emprestado indefinidamente aumentando a remuneração exigida por parte dos trabalhadores em relação aos depósitos à vista, levando o spread à zero. O risco moral envolvido na atividade bancária é a escolha que os banqueiros podem fazer a cada período de operar honestamente ou desviar uma proporção de seus recursos indevidamente e, no momento seguinte, serem penalizados pelos financiadores e obrigados a deixarem o mercado. A intuição econômica dada a este desvio moral dos bancos varia na literatura, uma forma que parece intuitiva é pensar que o banco tem a opção de não alocar de maneira eficiente os recursos que o financiam e com isso, coloca em risco o empréstimo feito a ele. Podemos pensar na restrição como um mecanismo dos emprestadores para garantir um contrato de "investimento eficiência" 4 .

Contrariamente à Aoki, Benigno e Kiyotaki (2016), assumimos que a capacidade dos bancos em agir de maneira desleal é estritamente crescente na proporção de ativos financiados externamente, dívida externa e, portanto, decrescente em poupança externa. A intuição que defendemos, e pensando no caso brasileiro, é que os agentes externos têm menos conhecimento dos riscos associados a cada banco, têm mais custos para recorrer à justiça local, que possivelmente pode ter um viés pró bancos domésticos. Ao mesmo tempo, também podemos pensar que na oposição bancos $\mathrm{X}$ trabalhadores, a justiça pode tender a favorecer mais os credores, impondo ao banqueiro prejuízo maior quanto maior a parcela de fundos domésticos ele possuir no momento do desvio. Para além disso, ao montarmos o problema dessa forma, a intuição para a condição de compatibilidade de incentivos ser ativa no ótimo se torna mais similar àquela proposta por Gertler e Kiyotaki (2015), neste que avaliamos como o artigo mais nítido a respeito desta formatação de sistema financeiro. Finalmente, o objetivo central para induzir que os incentivos ao desvio cresçam conforme a proporção de dívida externa é garantir uma vantagem adicional a esta forma de financiamento, reforçando o benefício privado da dívida em moeda estrangeira, em detrimento do custo social. Uma hipótese que parece intuitiva, de que bancos com comportamento mais arriscado também são aqueles mais dispostos a obter recursos de fundos mais incertos. Formalmente, a fração de fundos desviáveis se define por:

$$
\Theta\left(x_{t}\right)=\theta_{0} \exp \left(\theta x_{t}\right)
$$

em que $\theta_{0}$ é a parcela de fundos apropriada privadamente no momento do desvios, $\theta$ mede quão mais sujeito ao desvio o banco se torna conforme cresce a proporção de endividamento externo $x_{t}=\frac{\epsilon_{t} d_{t}^{*}}{Q_{t} k_{t}^{b}}$.

Ao mesmo tempo, mantemos a hipótese de Aoki, Benigno e Kiyotaki (2016) de que o endividamento externo é crescentemente custoso do ponto de vista de recursos. Na nossa perspectiva, refinamos esta hipótese uma vez que damos à ela racionalidade compatível ao problema moral do banco. Isto é, sabendo que os bancos se tornam mais propensos ao desvio quanto mais se endividam externamente, maiores dificuldades são impostas ao acesso no mercado internacional par um banco altamente endividado em moeda estrangeira. Além disso, na especificação dos autores este custo era quadrático o que possui duas implicações: a primeira é que a taxa de variação do custo diante de um crescimento do endividamento

\footnotetext{
${ }^{4}$ Em referência ao exemplo clássico de salário eficiência de Shapiro e Stiglitz (1984), por exemplo.
} 
é mais elevada, o que corrigimos ajustando o parâmetro de $\kappa_{b}$ para manter vazamento semelhante no Estado Estacionário; a segunda é que, ao ser quadrático, o custo se torna positivo caso o banco poupe no exterior, isto é, caso $d_{t}^{*}<0$, o que vai contra a intuição que se propõe para a existência deste custo. Ou seja, neste modelo, se o banco poupa externamente este custo se torna um subsídio, ele é bem visto em mercados internacionais e possui melhor relação com os investidores. Do ponto de vista da escolha ótima do banco, por mais que tenhamos reforçado o incentivo ao financiamento externo via Equação 43, incluímos este contrapeso:

$$
\chi^{b}\left(\epsilon_{t} d_{t}^{*}, Q_{t} k_{t}^{b}\right)=\kappa_{b} x_{t} Q_{t} k_{t}^{b}
$$

Sendo assim, o equilíbrio do balanço dos bancos gera as seguintes relações que garantem a necessária consistência entre os fluxos e estoques do setor:

$$
\begin{aligned}
{\left[1+\tau_{t}^{K}+\kappa_{b} x_{t}\right] Q_{t} k_{t}^{b} } & =\left(1+\tau_{t}^{n}\right) n_{t}+d_{t}+\left(1-\tau_{t}^{d}\right) \epsilon_{t} d_{t}^{*} \\
n t & =\left(S_{t}+\lambda Q_{t}\right) k_{t-1}^{b}-R_{t} d_{t-1}-\epsilon_{t} \Gamma_{t} d_{t-1}^{*}
\end{aligned}
$$

Em que $\Gamma_{t}$ é a taxa efetiva exigida pelos financiadores internacionais para financiarem os bancos domésticos. Diferentemente do artigo de referência, especificamos de que forma essa taxa depende do nível dos juros externos vigentes de $t-1$ a $t, R_{t}^{*}$, mais um prêmio de risco. Para incorporar especificamente a evidência de Rey (2015), definimos que o prêmio de risco, $V_{t}^{r}$, possui um elemento autorregressivo e varia positivamente conforme a taxa de juros se torna maior do que aquela vigente em equilíbrio, $R^{*}$. Além disso, em uma hipótese própria, lastreada nos eventos recentes da economia mundial, assumimos que uma recessão internacional aumenta a preferência pela liquidez dos financiadores externos que deixam de financiar os países periféricos, mesmo com a redução da taxa de juros internacional.

$$
\begin{aligned}
\Gamma_{t} & =R_{t}^{*}+V_{t}^{r}\left(R_{t}^{*}, Y_{t}^{*}\right) \\
V_{t}^{r} & =\rho_{v} V_{t-1}^{r}+\rho_{R^{*}}\left(R_{t}^{*}-R^{*}\right)-\rho_{Y *}\left(\ln \left(Y_{t}^{*}\right)-\ln \left(Y^{*}\right)\right)+\varepsilon_{t}^{v}
\end{aligned}
$$

Ao final do período $t$, antes da realização das incertezas em $t+1$, o banco precisa escolher se irá desviar fundos e ser forçado a sair do mercado em $t+1$ ou seguir operando honestamente. De tal forma que a decisão é tomada ponderando $V_{t}$ e o ganho esperado do desvio. Como os credores são racionais e antecipam o comportamento dos banqueiros, qualquer contrato de crédito só será firmado caso valha a seguinte compatibilidade de incentivos:

$$
V_{t} \geq \Theta\left(x_{t}\right) Q_{t} k_{t}^{b}
$$

O problema do banqueiro pode ser expresso de maneira recursiva como maximizar:

$$
V_{t}=\mathbb{E}_{t}\left\{\Lambda_{t, t+1}\left[(1-\sigma) n_{t+1}+\sigma V_{t+1}\right]\right\}
$$

sujeito à restrição do balanço patrimonial, Equação 45, e à compatibilidade de incentivos, Equação 49. Como essas restrições e à função objetivo são sujeitas à retornos constantes de escala, podemos reescrever a função valor da seguinte forma:

$$
\psi_{t} \equiv \frac{V_{t}}{n_{t}}=\mathbb{E}_{t}\left[\Lambda_{t, t+1}\left(1-\sigma+\sigma \psi_{t+1}\right) \frac{n_{t+1}}{n_{t}}\right]
$$


Como sugerido na maior parte das referências dessa literatura, podemos interpretar $\psi$ como uma medida do Q de Tobin do banco. Segue-se agora com o problema do banco, cujos detalhes da derivação podem ser encontrados no Apêndice C. Seja $\phi_{t}=\frac{Q_{t} k_{t}^{b}}{n_{t}}$ a alavancagem dos bancos, podemos definir $\frac{n_{t+1}}{n_{t}}$ como:

$$
\begin{gathered}
\frac{n_{t+1}}{n_{t}}=\frac{S_{t}+\lambda Q_{t}}{Q_{t}} \frac{Q_{t} k_{t}^{b}}{n_{t}}-R_{t+1} \frac{d_{t}}{n_{t}}-\Gamma \frac{\epsilon_{t+1}}{\epsilon_{t}} \frac{\epsilon_{t} d_{t}^{*}}{n t} \\
=\left[\frac{S_{t}+\lambda Q_{t}}{Q_{t}}-\left(1+\tau_{t}^{K}\right) R_{t+1}\right] \phi_{t}+\left[\left(1-\tau_{t}^{d}\right) R_{t+1}-\Gamma \frac{\epsilon_{t+1}}{\epsilon_{t}}\right] x_{t} \phi_{t}+\left(1+\tau_{t}^{N}-\kappa_{b} x_{t} \phi_{t}\right) R_{t+1}
\end{gathered}
$$

O problema do banco então se torna escolher sua alavancagem e proporção de endividamento externo.:

$$
\begin{aligned}
& \psi_{t}=\underset{\phi_{t}, x_{t}}{\operatorname{Max}}\left[\mu_{t} \phi_{t}+\mu_{t}^{*} \phi_{t} x_{t}+\left(1+\tau_{t}^{N}-\kappa_{b} x_{t} \phi_{t}\right) v_{t}\right] \\
& \quad \text { s.a } \\
& \psi_{t} \geq \Theta\left(x_{t}\right) \phi_{t}=\theta_{0} \exp \left(\theta x_{t}\right) \phi_{t}
\end{aligned}
$$

em que:

$$
\begin{aligned}
\mu_{t} & =\mathbb{E}_{t}\left\{\Omega_{t+1}\left[\frac{S_{t}+\lambda Q_{t}}{Q_{t}}-\left(1+\tau_{t}^{K}\right) R_{t+1}\right]\right\} \\
\mu_{t}^{*} & =\mathbb{E}_{t}\left[\left(1-\tau_{t}^{d}\right) R_{t+1}-\Gamma \frac{\epsilon_{t+1}}{\epsilon_{t}}\right] \\
v_{t} & =\mathbb{E}_{t}\left\{\Omega_{t+1} R_{t} t+1\right\} \\
\Omega_{t+1} & =\Lambda_{t, t+1}\left(1-\sigma+\sigma \psi_{t+1}\right)
\end{aligned}
$$

Ou seja, $\Omega_{t+1}$ é o fator de desconto intertemporal do banqueiro, $v_{t}$ é o custo marginal dos depósitos bancários, $\mu_{t}$ representa o ganho de se investir em capital frente ao custo dos depósitos domésticos, $\mu_{t}^{*}$ é a vantagem do financiamento externo em relação ao financiamento doméstico, e, para efeito de comparação com os modelos tradicionais de macroeconomia aberta, sintetiza o que há de mais próximo a uma paridade descoberta nesta economia. Restringindo nossa atenção para os casos em que $\psi$ é estritamente crescente em $x_{t}, \phi_{t}$, sabemos que a restrição será satisfeita com igualdade caso o benefício marginal de operar honestamente seja menor do que o ganho marginal do desvio. Isto é, quando $\left(\Theta\left(x_{t}\right) \phi_{t}\right)^{\prime}>\left(\psi_{t}\right)^{\prime}$. Intuitivamente, como tanto a restrição como a função objetivo são crescentes nos parâmetros, enquanto for possível aumentar a função valor sem desrespeitar a restrição, o banco continuará elevando $x_{t}, \phi_{t}$, até que a restrição passa a crescer mais rapidamente e no ótimo vale com igualdade. O Apêndice $\mathrm{C}$ discute este elemento e mostra que, quando é atendido, as seguintes relações são verificadas:

$$
\begin{aligned}
\phi_{t} & =\frac{\left(1+\tau_{t}^{N}\right) v_{t}}{\Theta\left(x_{t}\right)+\kappa_{b} x_{t} v_{t}-\left(\mu_{t}+\mu_{t}^{*} x t\right)} \\
\psi_{t} & =\Theta\left(x_{t}\right) \phi_{t} \\
x_{t} & =\frac{\frac{\mu_{t}}{v_{t}}}{\kappa_{b}-\frac{\mu_{t}^{*}}{v_{t}}}+\frac{1}{\theta}
\end{aligned}
$$


Lá também é demonstrado que tanto $x_{t}$, como $\phi_{t}$ são funções crescentes de $\frac{\mu_{t}}{v_{t}}, \frac{\mu_{t}}{v_{t}}$. Ou seja, quando melhora o custo do financiamento externo em relação ao doméstico, ou quando aumenta o retorno do investimento em capital sobre o custo de financiamento bancário, aumenta-se a alavancagem e a proporção de depósitos externos nos passivos dos bancos. Da mesma forma, fica evidente que $\phi_{t}$ é função decrescente do parâmetro de risco moral $\theta_{0}$. Por fim, a Equação 57 limita o tamanho da alavancagem do banco no ponto em que o ganho por unidade de patrimônio líquido de desviar fundos, $\left(\Theta\left(x_{t}\right)\right) \phi_{t}$ equivale ao custo de perder o valor futuro da franquia, $\psi_{t}$. Tal como em Gertler e Kiyotaki (2015), o "preço sombra"do valor do patrimônio líquido do banco excede a unidade em equilíbrio e o portfólio do banco é restringido endogenamente por seu próprio balaço patrimonial, gerando o efeito de acelerador financeiro discutido anteriormente.

\subsubsection{Setor Externo e Variáveis Exógenas}

O Setor externo é composto por duas variáveis exogenamente determinadas, $Y_{t}^{*}$ e $R_{t}^{*}$, que podem ser entendidas respectivamente como toda a demanda externa ao qual o país periférico responde, e a taxa de juros internacional básica. Pensando desta forma, entende-se $Y^{*}$ como a demanda mundial a qual está sujeita a variações da taxa de juros $R_{t}^{*}$, essa, por suavez, entendida como uma taxa cobrada para empréstimos em dólares, definida largamente pelo FED. Ou seja, a suposição um tanto forte que é feita é que a demanda externa está sujeita a variações da taxa de juros dos EUA, mas essa por sua vez não responde à variações na demanda.

$$
\begin{gathered}
\ln \left(Y_{t}^{*}\right)=\rho_{y^{*}} \ln \left(Y_{t-1}^{*}\right)-\left(1-\rho_{y}^{*}\right) \omega_{y r}\left(R_{t-1}^{*}-R^{*}\right)+\varepsilon_{t}^{y} \\
R_{t}^{*}=\rho_{r} R_{t-1}^{*}+\left(1-\rho_{r}\right) R^{*}+\varepsilon_{t}^{r}
\end{gathered}
$$

Além disso, o choque de produtividade agregado ao qual a economia está sujeita pode ser descrito pelo seguinte processo autorregressivo:

$$
\ln \left(Z_{t}\right)=\rho_{z} \ln \left(Z_{t-1}\right)+\varepsilon_{t}^{z}
$$

\subsubsection{Equilíbrio de Mercado}

Com o modelo estabelecido pelas equações anteriores, descreve-se aqui o equilíbrio de mercado. O produto deve ser consumido, investido, exportado ou gasto nos custos associados às alterações de preço, financiamento direto das famílias e endividamento externo dos bancos, de tal forma que temos:

$$
Y_{t}=C_{t}\left[1+\Phi\left(\frac{I_{t}}{t}\right)\right] I_{t}+E x_{t}+\frac{\kappa}{2}\left(\pi_{t}-1\right)^{2} Y_{t}+\chi^{h}\left(K_{t}^{h}, K_{t}\right)+\chi^{b}\left(\epsilon_{t} D_{t}^{*}, Q_{t} K_{t}^{b}\right)
$$

O Produto Interno Bruto desta economia, portanto, é obtido por $Y_{t}^{P I B}=Y_{t}-\epsilon_{t} M_{t}$, e a Renda Nacional Líquida:

$$
Y_{t}^{l}=Y_{t}-\epsilon M_{t}-\frac{\kappa}{2}(\pi-1)^{2} Y_{t}-\chi^{h}\left(K_{t}^{h}, K_{t}\right)-\chi^{b}\left(\epsilon_{t} D_{t}^{*}, Q_{t} K_{t}^{b}\right)
$$


Além disso, o equilíbrio em transações correntes garante que:

$$
D_{t}^{*}=\Gamma_{t} D_{t}^{*}+M_{t}-\frac{1}{\epsilon_{t}} E x_{t}
$$

Em relação aos bancos, o patrimônio líquido agregado deve evoluir de acordo com o retorno de investimentos menos os custos dos bancos que permanecem operando, mais os ativos dispostos pelos novos banqueiros:

$$
N_{t}=\sigma\left[\left(S_{t}+\lambda Q_{t}\right) K_{t-1}^{b}-R_{t} D_{t-1}-\epsilon_{t} \Gamma_{t} D_{t-1}^{*}\right]+\xi\left(S_{t}+\lambda Q_{t}\right) K_{t-1}^{b}
$$

enquanto o equilíbrio do balanço de patrimonial, no agregado, implica:

$$
\begin{gathered}
Q_{t} K_{t}^{b}\left(1+\kappa_{b} x_{t}\right)=\left(1+\kappa_{b} x_{t}\right) \phi_{t} N_{t} \\
Q_{t} K_{t}^{b}\left(1+\kappa_{b} x_{t}\right)=N_{t}+D_{t}+\epsilon_{t} D_{t}^{*} \\
x_{t}=\frac{\epsilon_{t} d_{t}^{*}}{Q_{t} K_{t}^{b}}
\end{gathered}
$$

O equilíbrio no mercado de capitais garante que:

$$
K_{t}=K_{t}^{b}+K_{t}^{h}
$$

Finalmente, a política monetária doméstica é conduzida pela autoridade monetária de acordo com a seguinte Regra de Taylor, convencional a este tipo de modelo, na qual o juro nominal varia em um processo autorregressivo e de acordo com uma determinada aversão à inflação por parte do Banco Central, tal que:

$$
i_{t}-i=\left(1-\rho_{i}\right) \omega_{\pi}(\pi-1)+\rho_{i}\left(i_{t-1}-i\right)+\varepsilon_{t}^{i}
$$

Por fim, o equilíbrio competitivo recursivo é caracterizado por oito preços $\left(m c_{t}, \pi_{t}, S_{t}, w_{t}, i_{t}, \epsilon_{t}\right.$, $\left.Q_{t}, \tau_{t}^{N}\right), 12$ quantidades $\left(Y_{t}, M_{t}, L_{t}, C_{t}, I_{t}, K_{t}, E x_{t}, N_{t}, K_{t}^{b}, K_{t}^{h}, D_{t}, D_{t}^{*}\right)$ e seis variáveis bancárias $\left(x_{t}\right.$, $\left.\psi_{t}, \phi_{t}, \nu_{t}, \mu_{t}, \mu_{t}^{*}\right)$ como função das variáveis de estado $K_{t-1}, K_{t-1}^{b}, D_{t-1}, D_{t-1}^{*}, i_{t-1}, R *_{t-1}, R_{t}^{*}, Y_{t}^{*}, Z_{t}$, $\left.V_{t}, V_{t-1}\right)$ e definido pelo conjunto de equações (29), (31 - 40), (42), (52-54), (56-58), (62), (64-70).

\subsection{Experimentos e Análise dos Resultados}

Nesta seção serão descritos os resultados de diferentes experimentos conduzidos a partir do modelo desenvolvido na seção anterior. As Tabela 2 e a Tabela 3 descrevem, respectivamente, os valores dos parâmetros utilizados na análise, salvo em alguns casos que serão formalmente explicitados, e os valores de algumas variáveis no Estado Estacionário Não-Estocástico, derivado no apêndice Apêndice D. As variáveis tiveram seus padrões definidos em consonância com a literatura, e, em especial. com os artigos de Aoki, Benigno e Kiyotaki (2016), Landi (2017) e Carvalho, Castro e Costa (2014). 
Tabela 2 - Parâmetros do Cenário Base

Firmas

\begin{tabular}{|c|c|c|}
\hline$\alpha_{k}$ & participação do capital nos custos & 0.33 \\
\hline$\alpha_{m}$ & participação da importação nos custos & 0.15 \\
\hline$\lambda$ & um menos a depreciação & 0.98 \\
\hline$\eta$ & elasticidade de substituição da demanda & 11 \\
\hline$\omega$ & fração das firmas que não ajustam preço & 0.10 \\
\hline$\kappa_{I}$ & custo de ajustar o investimento & 2.6 \\
\hline$\varphi$ & elasticidade preço das exportações & 1 \\
\hline
\end{tabular}

\section{Famílias}

\begin{tabular}{|c|c|c|}
\hline$\beta$ & taxa de desconto & 0.982 \\
\hline$\zeta$ & inverso da elasticidade de Frisch & 0.333 \\
\hline$\zeta_{0}$ & inverso da capacidade de oferta de trabalho & 8.1 \\
\hline$\kappa_{h}$ & custo administrativo do finaciamento direto & 0.04 \\
\hline
\end{tabular}

Bancos

\begin{tabular}{|c|c|c|}
\hline$\theta$ & elasticidade div. externa da alavancagem & 0.175 \\
\hline$\theta_{0}$ & proporção de ativos desviáveis & 0.65 \\
\hline$\sigma$ & prob. de sobreviência dos bancos & 0.91 \\
\hline$\xi$ & fração dos ativos total dos novos banqueiros & 0.00036 \\
\hline$\kappa_{b}$ & custo administrativo do endiv. externo & 0.009 \\
\hline$\theta_{0}$ & proporção de ativos desviáveis & 0.65 \\
\hline$\kappa_{b}$ & custo administrativo do endiv. externo & 0.009 \\
\hline$\rho_{v}$ & coef. autocorrelação do prêmio de risco & 0.5 \\
\hline$\rho_{R^{*}}$ & sensibilidade juros externo do risco & 0.7 \\
\hline$\rho_{Y^{*}}$ & sensibilidade demanda global do risco & 0.05 \\
\hline
\end{tabular}

Set. Externo e demais parâmetros

\begin{tabular}{|c|c|c|}
\hline$\rho_{y^{*}}$ & coef. autocorrelação demanda global & 0.9 \\
\hline$\omega_{y r}$ & sensibilidade demanda global ao juros externo & 0.5 \\
\hline$\rho_{r}$ & coef. autocorrelação juros externo & 0.9 \\
\hline$\rho_{z}$ & coef. autocorrelação produtividade & 0.9 \\
\hline$\rho_{i}$ & parâmetro de suavização da pol. mon. & 0.8 \\
\hline$\omega_{\pi}$ & aversão à inflação autoridade monetária & 1.5 \\
\hline
\end{tabular}

A elasticidade de substituição de bens intermediários, $\eta$, e o custo de ajustamento do investimento, $\kappa_{I}$, seguem os valores sugeridos para o Brasil em Carvalho, Castro e Costa (2014). Definimos $\alpha_{m}=0.15$ para garantir uma proporção de importações sobre o produto em equilíbrio de 15\%. Gouvea (2007) mostra que os preços no Brasil são bem mais flexíveis do que o observado nos países ricos, enquanto aqui a duração média é entre 2,7 a 3,8 meses, ou seja, menos que um trimestre, nos EUA a literatura sugere que esse valor vai de 8 a 11 meses. Diante deste fato, Aoki, Benigno e Kiyotaki (2016) sugerem que esta alta flexibilidade é satisfeita com $\omega=0.10$. Este valor é especialmente baixo em relação à media da literatura, mas condizente com a estimação empírica citada e, portanto, o cenário base terá o parâmetro de ajuste de preços calibrado nesta dimensão. O valor de $\lambda$ e $\alpha_{k}$ seguem o padrão da literatura. $\varphi$ é assumido como sendo igual a 1. Embora se saiba que o valor está provavelmente superdimensionado, opta-se por mantê-lo pois é o valor utilizado por Aoki, Benigno e Kiyotaki (2016), está em consonância com a literatura e, caso seja menor, significa que o efeito observado nos experimentos conduzidos deveriam ser ainda mais drásticos do ponto de vista do impacto sobre produto doméstico de choques externos negativos. 
Tabela 3 - Valores de Estado Estacionário (Anuais)

\begin{tabular}{|c|c|c|}
\hline$Q$ & preço do capital & 1 \\
\hline$\pi$ & inflação & 0.15 \\
\hline$R^{*}$ & juros externo & 1.03 \\
\hline$R^{*}$ & juros doméstico & 1.075 \\
\hline$\phi_{t}$ & alavancagem & 7.5 \\
\hline$x_{t}$ & endividamento externo dos bancos & 0.18 \\
\hline$Y^{p i b}$ & produto interno bruto (PIB) & 19.17 \\
\hline${\frac{\epsilon D^{*}}{Y}}^{\text {pib }}$ & endividamento externo/PIB & 0.25 \\
\hline$\frac{\epsilon M}{Y}^{p i b}$ & Importação/PIB & 0.15 \\
\hline$\frac{K}{Y}^{p i b}$ & relação capital produto/PIB & 1.8 \\
\hline$\frac{K}{K}^{b}$ & proporção do capital financiado por bancos & 0.75 \\
\hline$C$ & consumo das famílias & 15.92 \\
\hline$I$ & investimento & 2.77 \\
\hline$E X$ & exportações & 3.2 \\
\hline$I m$ & importação & 3.0 \\
\hline$l$ & horas de trabalho & 0.40 \\
\hline
\end{tabular}

Em relação às famílias, a escolha de $\beta$ determina uma taxa de juro real anual de $7,5 \%$, em linha com a média brasileira observada de entre 2009 à 2017. Determinou-se $\kappa_{h}$ para obter uma proporção de $3 / 4$ do capital financiado pelos bancos em equilíbrio, e $\zeta_{0}$ para atingir $40 \%$ do tempo dos trabalhadores destinados a trabalho, valor acima dos tradicionais $1 / 3$, mas incorporando também um elemento das economias periféricas de contratos de trabalho precários e alta informalidade. Seguimos Aoki, Benigno e Kiyotaki (2016) na escolha de $\zeta$.

Em linha com Landi (2017), $\sigma=0.91$ e $\xi=0.00036$ e definiu-se $\theta_{0}, \theta$ e $\kappa^{b}$, para atingir o endividamento externo de $25 \%$, alavancagem de 7,5 e spread bancário de $4 \%$ de acordo com o estimado para o Brasil pelo mesmo autor. Os parâmetros da função prêmio de risco contém um nível de discricionariedade maior. Definimos de tal forma que uma variação percentual de $10 \%$ na demanda agregada, constitua um mudança no apetite do risco dos agente de $1 \%$, o que nos parece baixo, entretanto, novamente, caso seja mais alto joga a favor dos resultados. Segundo a hipótese de Rey (2015), um terço das variações do prêmio de risco decorrem de variações da taxa de juros, escolhemos $\rho_{R^{*}}$ tal que a decomposição da variância do prêmio de risco seja condizente com os valores estimados ${ }^{5}$. Além disso, o prêmio de risco é uma série com menos dependência temporal do que a taxa de juros, por exemplo, por isso definimos $\rho_{v}=0.5$.

Carvalho, Castro e Costa (2014) sugerem um parâmetro de suavização da política monetária no brasil de 0.825 , em linha com o 0.8 aqui adotado e uma aversão a inflação de 1.9 , que foi o valor escolhido neste modelo. Seguimos Aoki, Benigno e Kiyotaki (2016) para definir $\rho_{z}=\rho_{y^{*}}=\rho_{r}=0.9$ e definimos $\omega_{y r}$ tal que uma variação de $10 \%$ no juros internacional signifique uma retração de $0.5 \%$ na demanda global. Todos os choques são não correlacionados e seus valores serão especificados a cada simulação.

Diante da simplicidade do modelo e do estabelecimento dos parâmetros com base em critérios gerais da literatura e não estimados, os resultados expressos nesta seção são apenas indicativos de trajetórias e possíveis cenários relativos e não medidas precisas dos efeitos em cada uma das variáveis. O

\footnotetext{
${ }^{5} \mathrm{Na}$ realidade, a decomposição indica que $29 \%$ da variância de $V^{r}$ decorre de variações na taxa de juros externa, este valor é mais baixo que os $33 \%$ estimados, o que pode significar que nem toda variação de VIX, variável observada por Rey, é repassada ao prêmio de risco exigido dos bancos domésticos.
} 
objetivo é entender, dada esta estrutura analítica, para um certo conjunto de parâmetros, de que maneira a economia reage a diferentes choques. A validade externa da análise é absolutamente limitada ao tanto que se acredita que o mundo opera de maneira mais ou menos distante daquilo que foi modelado, podendo inclusive ser não existente. Desde que mantida a consistência interna, o modelo é um mapeamento válido de relações econômicas em uma economia periférica, aberta e com setor financeiro, embora todo e qualquer questionamento ao método, à forma e às hipóteses levantadas sejam mais do que pertinentes, necessários. Tendo circunscrito os anseios desta análise, exploraremos os resultados de diversas especificações do modelo; porém, evidentemente, de forma não exaustiva. $\mathrm{O}$ arcabouço desenvolvido pelo artigo de referência e aqui adaptado permite uma vastidão de experimentos dos quais selecionamos aqueles que potencialmente mais auxiliem na compreensão do objetivo deste trabalho.

Antes de apresentar as simulações, a sequência de imagens a seguir mostra de que maneira um choque de aumento da taxa de juro externa se propaga na economia doméstica. o esquema busca ressaltar os principais canais de transmissão e a relação entre os setores econômicos, auxiliando na compreensão da próxima seção. Foram esquematizados 4 sequências de acontecimentos, pensando numa primeira rodada de impactos da piora da liquidez internacional.

As imagens ressaltam que a dinâmica prejudicial para a autoridade monetária, dependerá, fundamentalmente, de qual impacto sobre o produto. Ou seja, tal qual no modelo agregado, a política monetária será tão mais constrangida por um choque de elevação do juro externo, quanto menor for o impacto expansionista via balança comercial e quanto maior for o impacto contracionista via queda do investimento ${ }^{6}$.

Figura 7 - Propagação do Choque: impacto nas variáveis externas

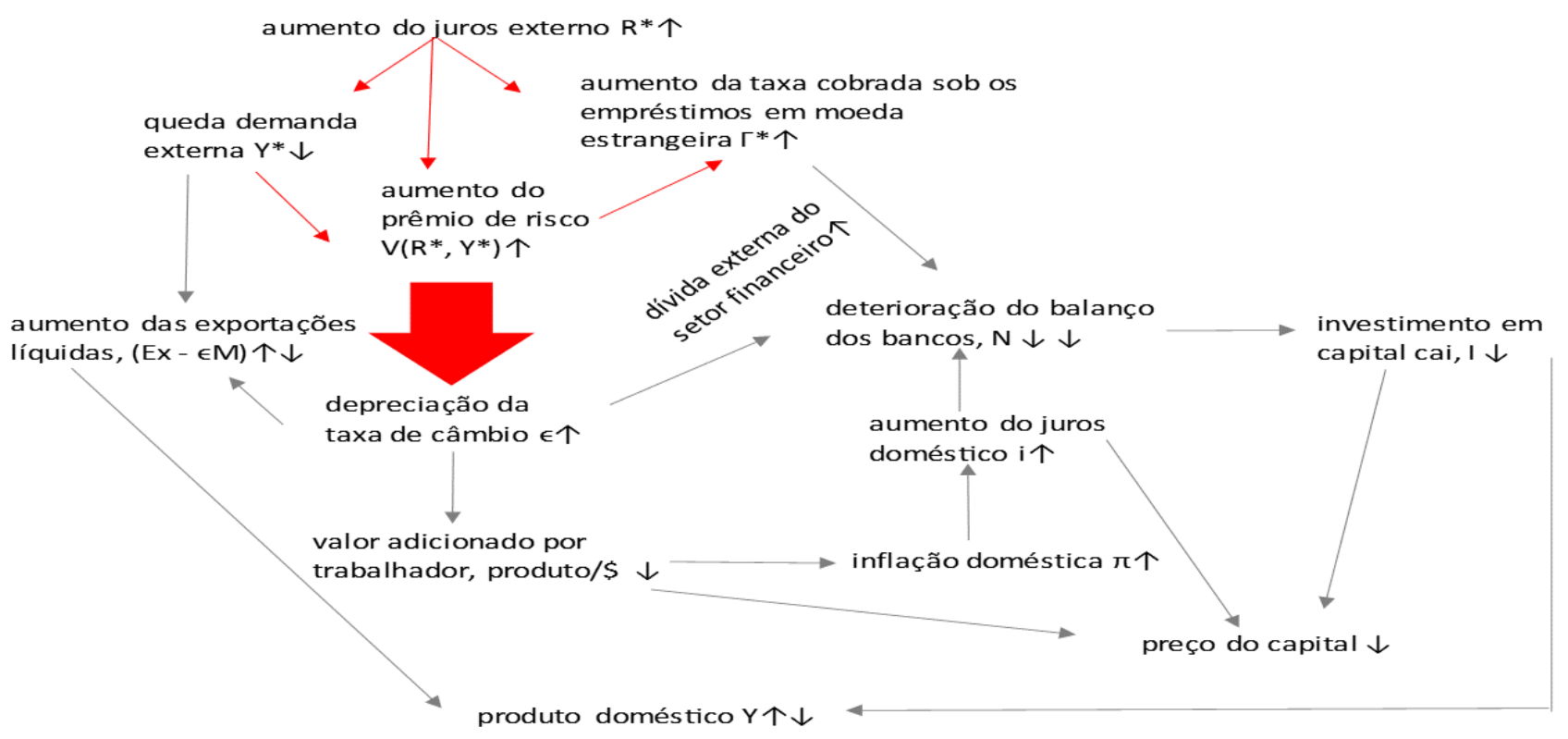

\footnotetext{
${ }^{6}$ Analisando essa mesma questão sobre outra perspectiva, Dalgic et al. (2018) mostra que o aumento do envidamento em dólar das firmas pode na verdade ser uma forma de seguro das famílias para momentos de forte desvalorização. Ele segue em outros artigos preliminares esta discussão e encontra para países como Turquia e Peru que uma desvalorização cambial não tem grandes impactos sobre o nível de investimento. Resta sendo um debate empírico
} 
Figura 8 - Propagação do choque: impacto na balança comercial

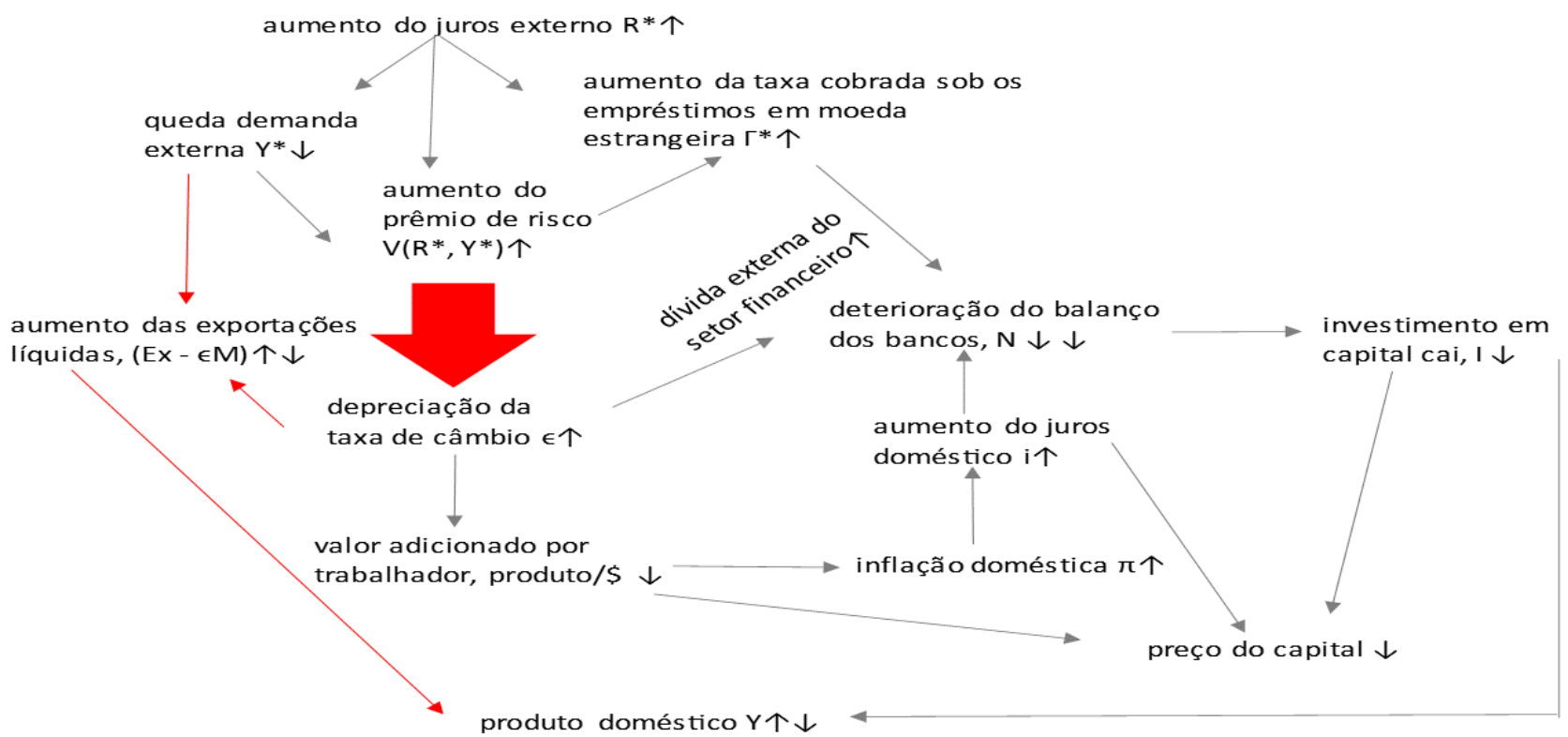

Figura 9 - Propagação do choque: impacto nas Firmas

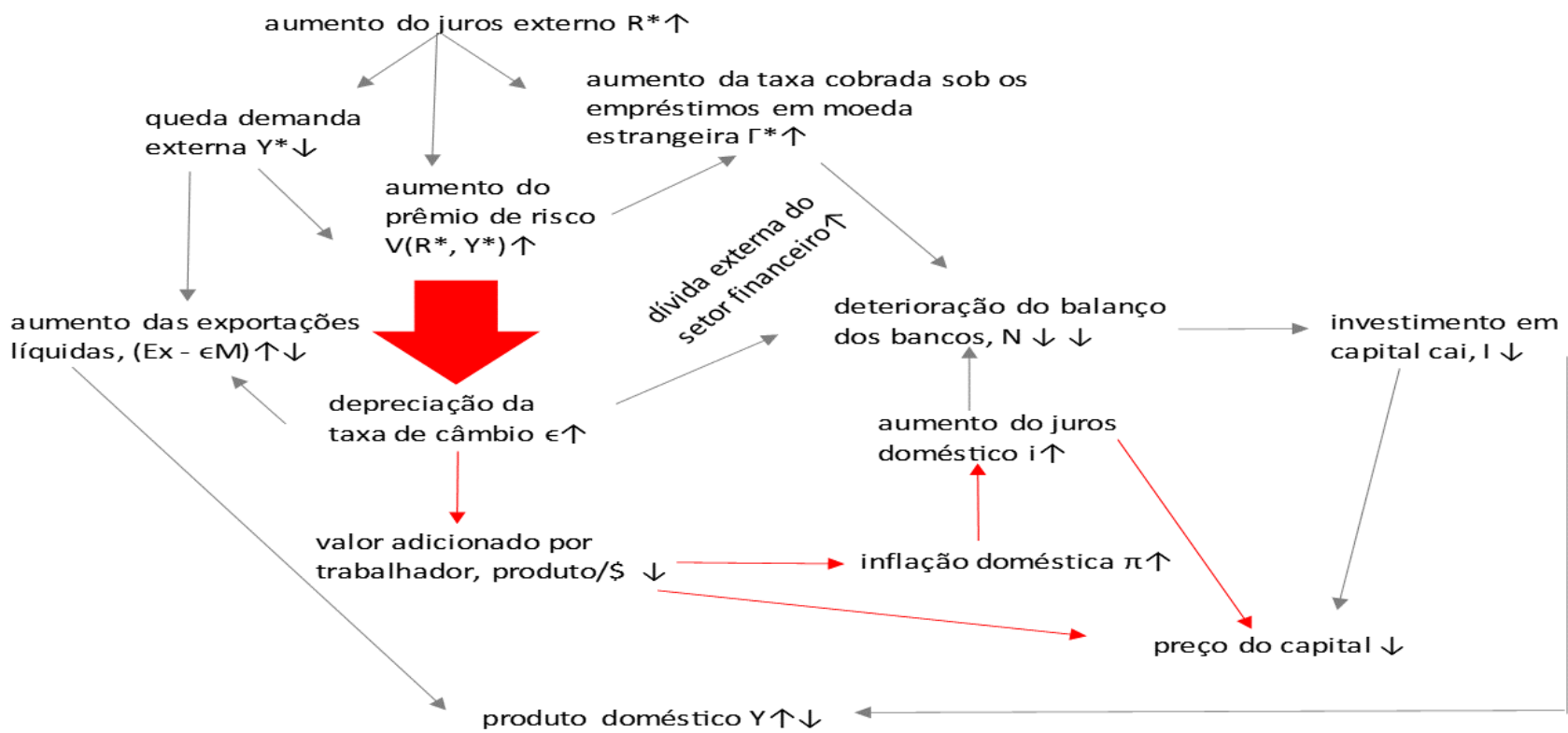


Figura 10 - Propagação do Choque: impacto no setor financeiro

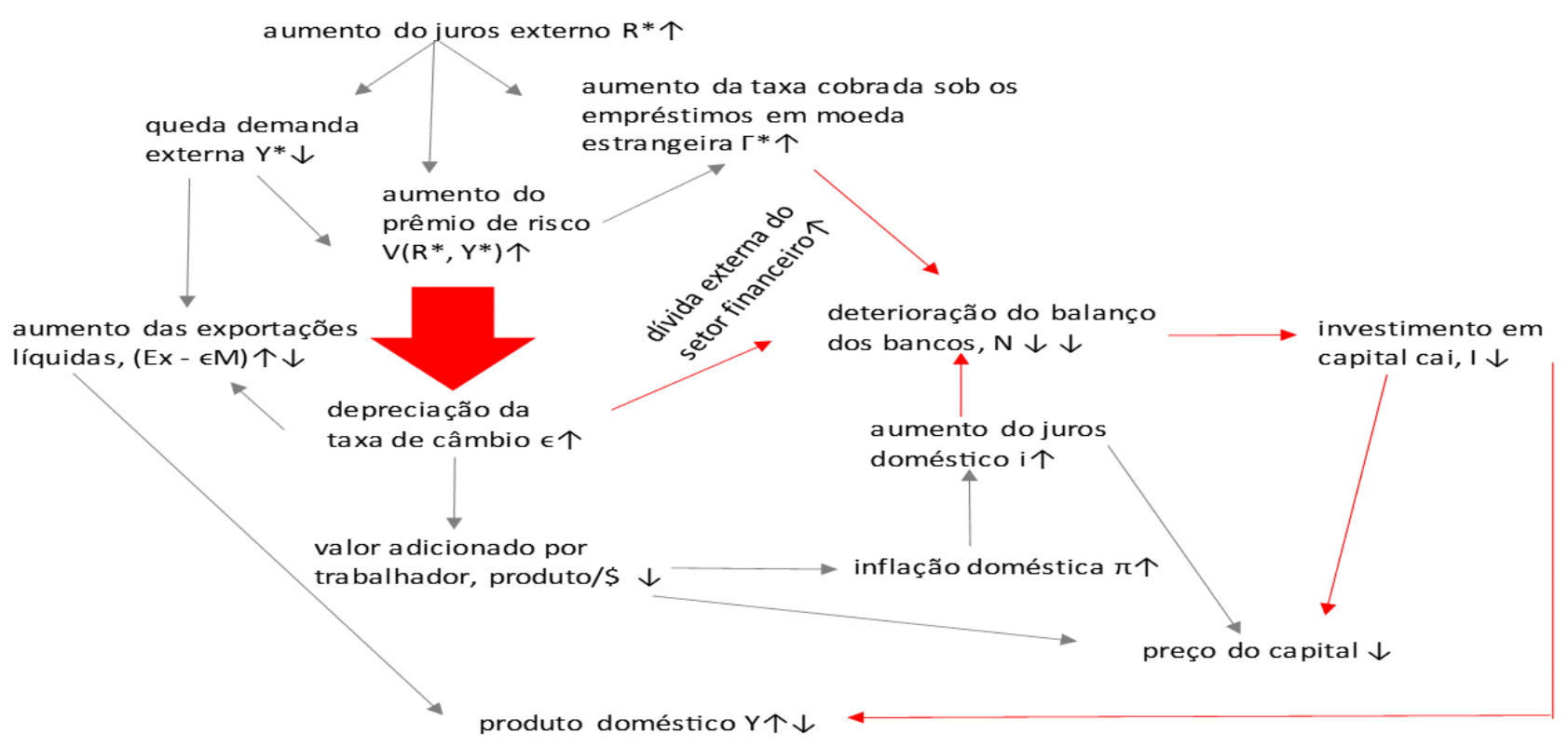

\subsubsection{Modelo Base}

Esta subseção apresenta os resultados referentes ao modelo descrito pelo equilíbrio competitivo estabelecido anteriormente ${ }^{7}$. O foco da análise desenvolvida nestes exercícios numéricos são os choques externos aos quais a economia esta submetida. Notadamente, variações do juros externo e da demanda global. Até mesmo visando maior nitidez expositiva, as análises em relação aos choques de produtividade e juros doméstico foram deixadas para os apêndices. Uma diferença importante desta pesquisa em relação ao que normalmente é analisado pela literatura é a relevância que é dada aos choques negativos de demanda internacional. A experiência histórica das economias emergentes não nos deixa duvidar da gravidade que uma corrida pela liquidez motivada por incertezas em relação à demanda global pode ter para a realidade doméstica.

A Figura 11 mostra as funções impulso resposta a um choque de $1 \%$ na taxa de juros externa $R^{*}$, em que as variáveis medidas em níveis no modelo estão expressas em logaritmo e as variáveis que são taxas permanecem assim, o que vale para o restante da análise. Ao ser atingida por um choque de juros externo, a economia doméstica inicia um processo recessivo. O aumento do custo de financiamento externo diminui a entrada de divisas, aumenta instantaneamente os custos de importação já contraídas e provoca uma forte desvalorização cambial de $4.5 \%$. O que gera uma melhora nas exportações e uma queda em sequência das importações melhorando a conta comercial. Dada a forma como modelamos $Y^{*}$, a demanda global cai o que impede uma melhora mais substantiva das exportações líquidas e aprofunda o caráter recessivo do choque para a economia doméstica.

A forte desvalorização cambial desencadeia dois processos centrais para a propagação do choque e em linha com a literatura anteriormente revisada. De um lado, há um significativo repasse cambial aos preços, o que desencadeia uma aumento de $1.2 \%$ na taxa de inflação doméstica e motiva uma subida da

\footnotetext{
${ }^{7}$ Todas as simulações foram feitas em aproximações de primeira ordem da solução do modelo.
} 
Figura 11 - Modelo Base: Choque de $+1 \%$ Taxa de Juros Externa (anual)
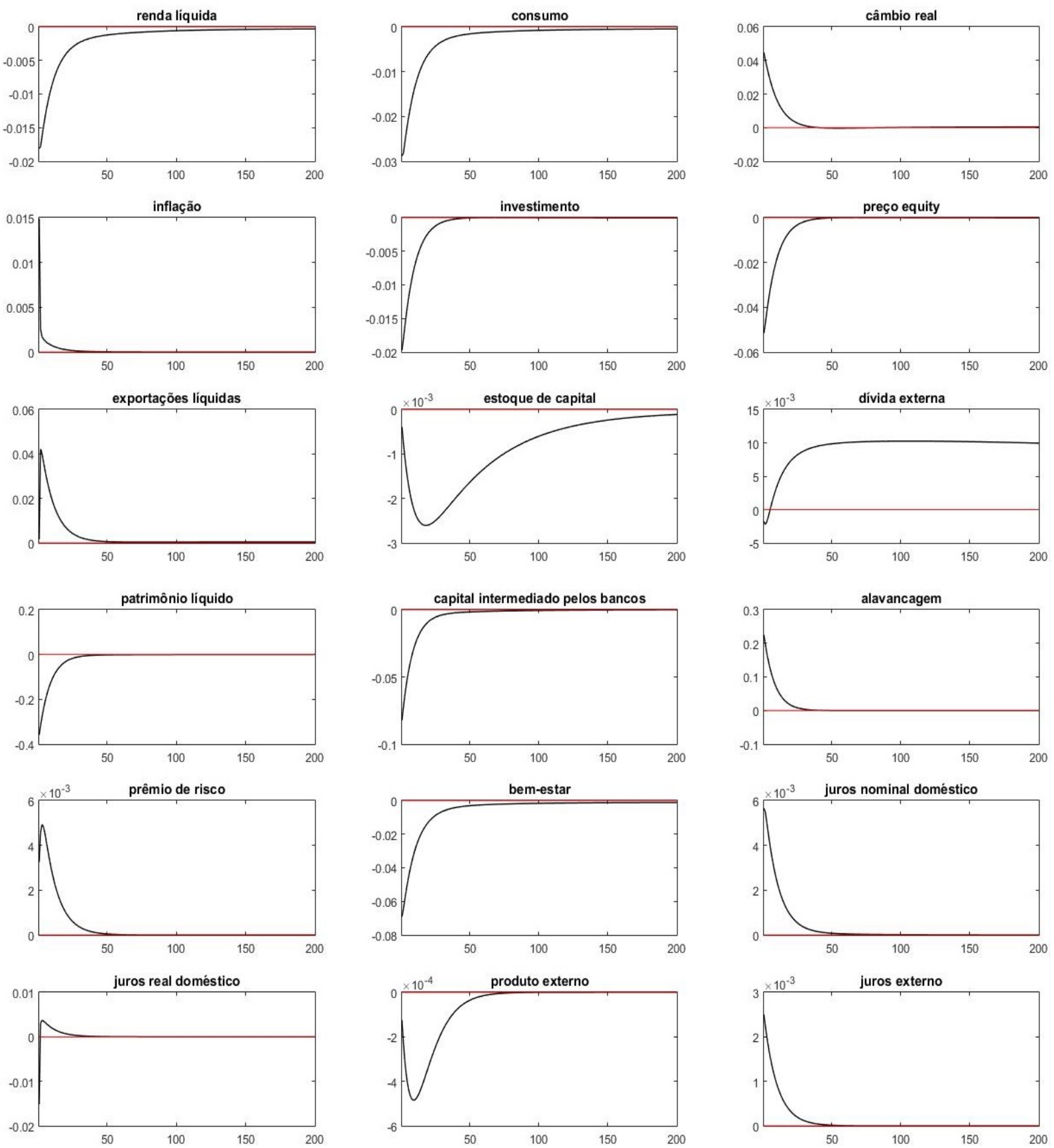

taxa de juros nominal pela autoridade monetária. Ao ser seguido pela taxa real, o aumento provoca uma queda no consumo e uma menor intermediação bancária para o setor de bens de capital, bem como uma mudança da preferência das famílias no sentido dos depósitos bancários. A queda da demanda por equity, faz com que o preço $Q$ caia substancialmente, o que diminui ainda mais a demanda por ações e reduz o investimento da economia, colocando-a em uma trajetória recessiva duradoura.

Ao mesmo tempo, a desvalorização cambial também piora o balanço dos bancos, reduzindo em $4 \%$ o patrimônio líquido. Em linha com a evidência empírica de Bruno e Shin (2015), uma desvalorização do dólar está associada, via o efeito da piora do balanço, a uma redução da oferta de crédito dos bancos 
às firmas, $K^{b}$, o que, por sua vez, contribui para a queda em $Q$ e reforça o processo recessivo. A queda do investimento derruba o estoque de capital a tal ponto que ele não retorna ao seu patamar inicial. Outro fator que corrobora para a histerese do estoque de capital é a forte e permanente elevação da dívida externa $D^{*}$. A elevação se deve ao fato de que, com um aumento da taxa de juros, via Equação 64, aumenta-se o estoque da dívida e como não há uma elevação suficiente das exportações líquidas, com a estabilização do juros externo, $D^{*}$ se estabiliza num patamar permanentemente mais alto. Embora não seja nítido pela figura, isso implica uma estabilização do câmbio real também a um patamar mais alto para garantir que os bancos sigam financiando esta dívida, o que impede uma retomada mais substantiva do investimento em capital. Tudo isso, é claro, na ausência de qualquer outro choque.

Já a Figura 12 nos mostra a reação da economia doméstica a um choque negativo de demanda externa. O fato do experimento anterior conter também uma queda de $Y^{*}$ e de uma diminuição do produto global interferir, no modelo base, no prêmio de risco, tornam as duas situações bastante similares do ponto de vista dos movimentos gerais da economia: desvalorização cambial, inflação, diminuição da oferta de crédito e do investimento. Entretanto, uma diminuição mais substantiva de $Y^{*}$ vinculada a um choque direto não propicia uma melhora das exportações líquidas, o que, junto da variação do prêmio de risco, faz com a dívida externa suba ao mesmo patamar observado no choque anterior, mesmo sem o efeito de elevação dos juros externos. Em todas as demais variáveis, a dimensão deste choque é menor porém suficiente para gerar uma recessão continuada na economia, decorrência em especial da forte elevação da dívida via aumento do prêmio de risco e queda nas exportações líquidas ${ }^{8}$.

Esse choque mostra algumas das contradições impostas às autoridades monetárias de países emergentes. Diante de uma recessão global, a qual a maioria dos países ricos deve enfrentar por meio de uma redução da taxa juros, a periferia é obrigada a tomar medidas pró-cíclicas como a elevação do juros nominal, ou uma redução menor do que a necessária, o que aprofunda e torna mais duradoura a recessão. A perda de autonomia da política monetária mesmo diante do câmbio flutuante é latente neste exemplo, ainda que modesto do ponto de vista do repasse das condições de demanda global para o prêmio de risco.

$\mathrm{Na}$ Figura 13 observam-se os efeitos de um choque direto no prêmio de risco $\varepsilon_{t}^{v}$ na economia doméstica. Dada a modelagem explícita de como fatores externos impactam no prêmio de risco, podemos entender este choque como uma mudança da percepção que os investidores tem do país. Essa alteração pode ser fruto de uma mudança institucional doméstica ou fruto de eventos externos, como foi o caso na coordenação entre as crises dos países emergentes na década de 1990.

A principal diferença, do ponto de vista da economia doméstica, entre este choque e uma elevação da taxa de juros externa é o fato de ele não significar uma retração da demanda global. Entretanto, como a desvalorização cambial é menor do que aquela gerada pelo primeiro choque, o efeito positivo nas exportações líquidas é menor, o que junto da elevação de $\Gamma_{t}$ na mesma magnitude do que no choque de juros, gera uma elevação ainda maior da dívida externa, dificultando a recuperação dos investimentos em capital e mantendo a taxa de câmbio num patamar permanentemente mais alto. A mudança cambial motiva também uma elevação das exportações líquidas no longo prazo o que, por sua vez, faz com que a trajetória da dívida externa seja levemente declinante.

\subsubsection{Ciclo Financeiro Global}

Os resultados aqui apresentados são mais significativos do que os encontrados por Aoki, Benigno e Kiyotaki (2016) em relação ao impacto de um aumento da taxa de juros, tanto do ponto de vista da retração doméstica como em relação à desvalorização cambial. Enquanto este modelo indica uma

${ }^{8}$ Note que os gráficos estão apresentados em escalas diferentes 
Figura 12 - Modelo Base: Choque de - 1\% na demanda global
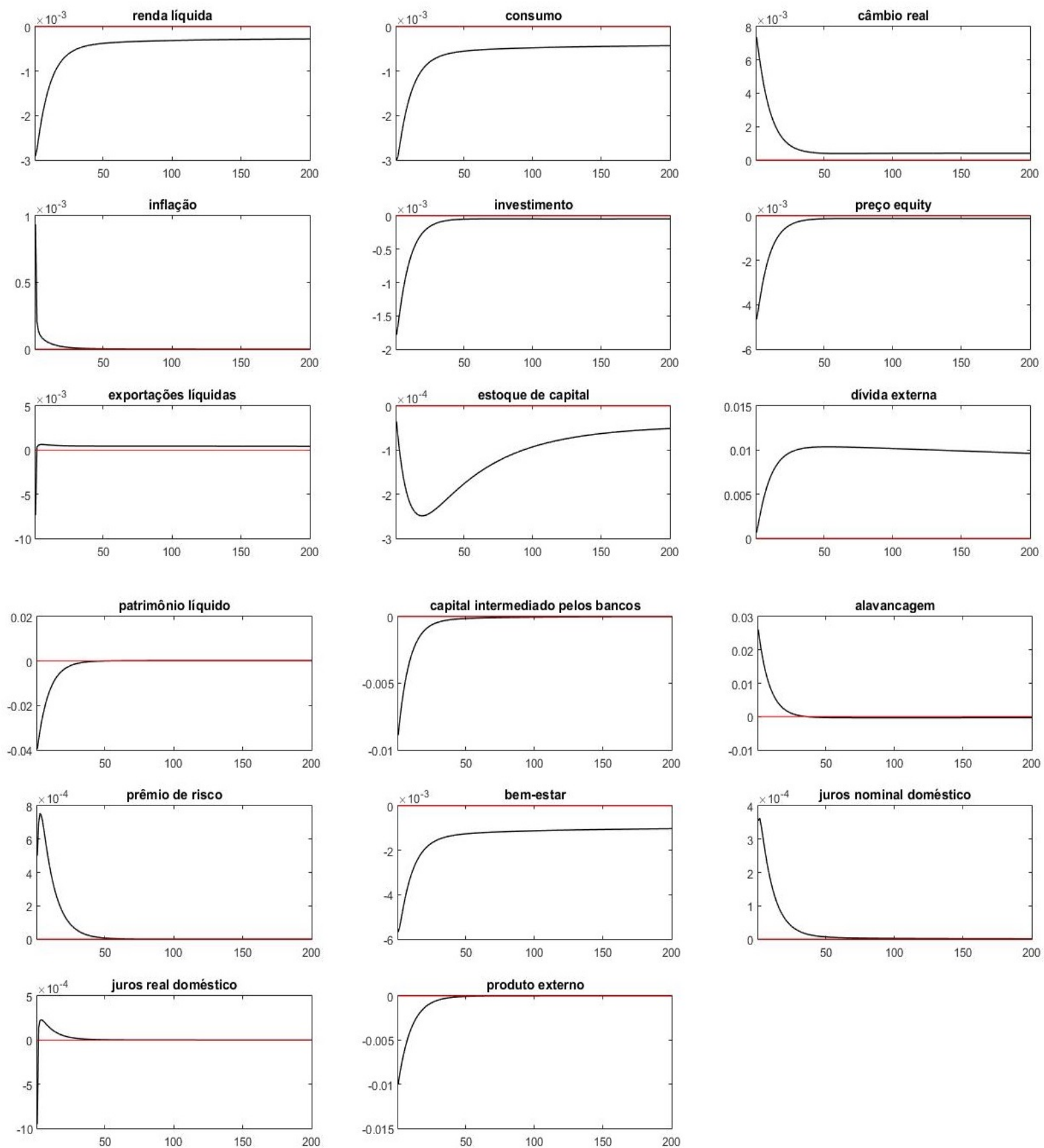

diminuição em quase $2 \%$ da renda líquida e uma desvalorização de $4.5 \%$ da taxa de câmbio, o efeito encontrado pelos autores é respectivamente de $0.45 \%$ e $1.8 \%$.

A diferença sugere que uma modelagem do Ciclo Financeiro Global, entendido como os impactos das condições econômicas globais sobre o prêmio de risco, é necessária para compreender melhor a transmissão da política monetária do centro para a periferia. Como os indicadores não são propriamente comparáveis entre os modelos do ponto de vista estritamente numérico, a Figura 14 e a Figura 15 comparam, diante de choques de juros e demanda externa, a resposta de algumas variáveis específicas nas duas formatações. Nas análises comparativas realizadas aqui, a linha preta e sólida sempre se refere ao 
Figura 13 - Modelo Base: Choque de 1\% no prêmio de risco
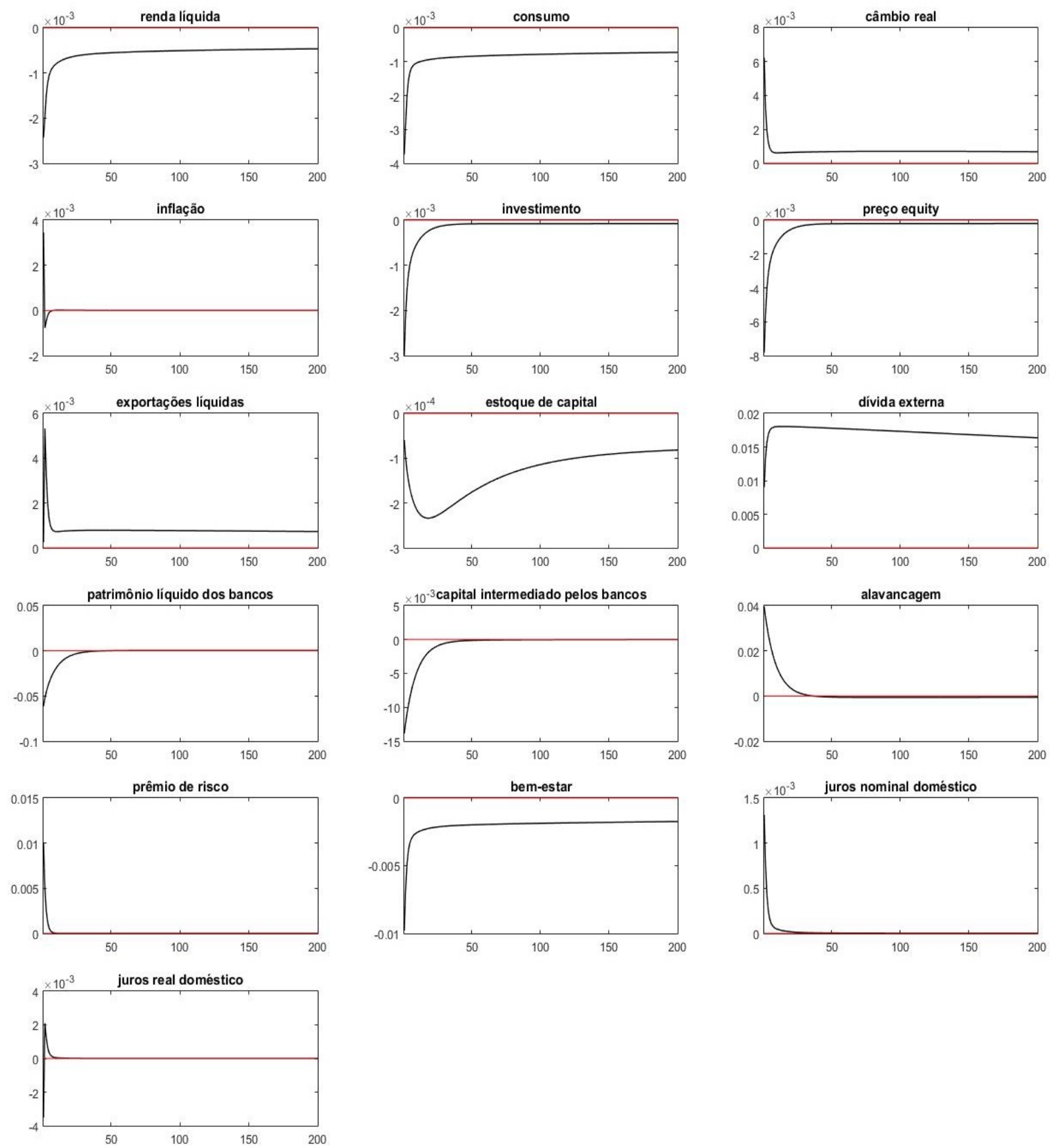

modelo base e a linha vermelha e tracejada representa a especificação alternativa

Percebemos pela primeira figura que a não consideração do prêmio de risco acarreta em um efeito de nível nas variáveis pós choque. Diminui-se o impacto da variação da taxa de juros externa na economia doméstica, mas mantém-se a direção do impacto. Efetivamente, a desvalorização do câmbio vai à $1.3 \%$, com consequentes menores impactos na taxa de inflação, no aperto da política monetária, na retração da renda, na elevação da dívida e sobre o estoque de capital.

Já em reação a um choque de demanda, há alteração no sentido da absorção do choque. Agora, ao não impactar a taxa de juros, a retração da demanda exterior impacta a economia doméstica apenas por 
meio da balança comercial. A queda das exportações gera tanto uma desvalorização cambial via diminuição da oferta de divisas como uma retração na renda, acompanhada por uma diminuição da inflação e taxa de juros nominal. Ao chegar na taxa de juro real, este impacto também implica uma maior rentabilidade do investimento em capital, o que é registrado pelo gráfico.

As funções ao fim mostram que a não consideração da cadeia cumulativa de causação entre juros externo, demanda global, prêmio de risco e a taxa cobrada dos empréstimos ao país emergente limitam a compreensão que se tem do problema da autoridade monetária. Embora eles já fossem evidentes mesmo sem isso, a sua inclusão implica um salto no nível e na transmissão do impacto. Motivando uma especificação mais robusta da racionalidade dos operadores externos futuramente.

\subsubsection{Inflação}

Um elemento importante observado por Aoki, Benigno e Kiyotaki (2016) é a relação entre a formação dos preços e a aversão da autoridade monetária à inflação com a forma na qual os choques externos se propagam pela economia doméstica. Eles sugerem que em um cenário de preços mais flexíveis - um $\omega$ menor - piora a dimensão do choque do ponto de vista do produto. A racionalidade é que ao reagirem mais rapidamente à desvalorização do câmbio, uma menor suavização do impacto inflacionário por parte das firmas torna a resposta da autoridade monetária mais brusca.

Como sugerido por (GOUVEA, 2007), o Brasil tem uma média de duração dos preços bastante menor daquela observada tradicionalmente para economias ricas. No modelo em questão, preços mais flexíveis são traduzidos em um $\omega$ menor, de 0.10 no caso, como no experimento realizado no modelo de referência. A figura 16 e a figura 17 comparam o impacto dos choques externos na renda, taxa de câmbio, dívida externa e estoque de capital no caso de uma maior rigidez de preços, ao considerar $\omega=0.66$, seguindo o valor de referências da literatura, em relação ao caso padrão de preços mais flexíveis.

Diante de um choque externo que possui consequências inflacionárias, o fato dos preços serem mais rígidos diminui o repasse cambial aos preços, exigindo uma resposta menos drástica da autoridade monetária. A intuição é que o choque de preços é mais absorvido pelo setor produtivo o que gera uma queda menor do produto de imediato. Ao não conseguir repassar o aumento do custo de importações para os preços, as firmas ajustam a produção e a demanda por insumos o que aprofunda a recessão, porém, dada a efemeridade do choque de câmbio, ao não provocar uma resposta tão rígida da política monetária, os efeitos são menores e menos duradouros do que no caso de preços flexíveis.

Contradizendo o postulado tradicional da literatura, preços mais rígidos ajudam a acomodar choque externos neste modelo. A maior vantagem dos preços relativamente flexíveis reside na melhora da balança comercial, majoritariamente via uma redução das importações, o que inclusive faz com que a depreciação cambial seja maior no cenário de preços mais rígidos. A cadeia de causação é análoga no caso de um choque negativo na demanda externa. As figuras 16 e 17 mostram os impactos distintos entre os dois regimes de preços na renda líquida, na taxa de câmbio, na inflação e na taxa real de juros.

Observa-se, portanto, que uma elevação de juros menor e menos imediata em reposta a um choque inflacionário que tem sua origem no câmbio diminui os impactos recessivos na economia doméstica diante de uma alteração dos juros externos. O motivo para esta acomodação neste caso são os preços mais rígidos, característica que, entretanto, não está sob a jurisdição da política monetária. Diferentemente, a aversão à inflação e a ponderação de desvios do produto para a determinação do juros nominal são de escolha política. Diante disso, dois experimentos são realizados. O primeiro altera a aversão da política monetária à inflação de tal forma que $\omega_{\pi}=1.2$, o segundo modifica a regra de Taylor desta economia de tal forma 
Figura 14 - Ciclo Financeiro Global: Choque de - 1\% na taxa de juros 1
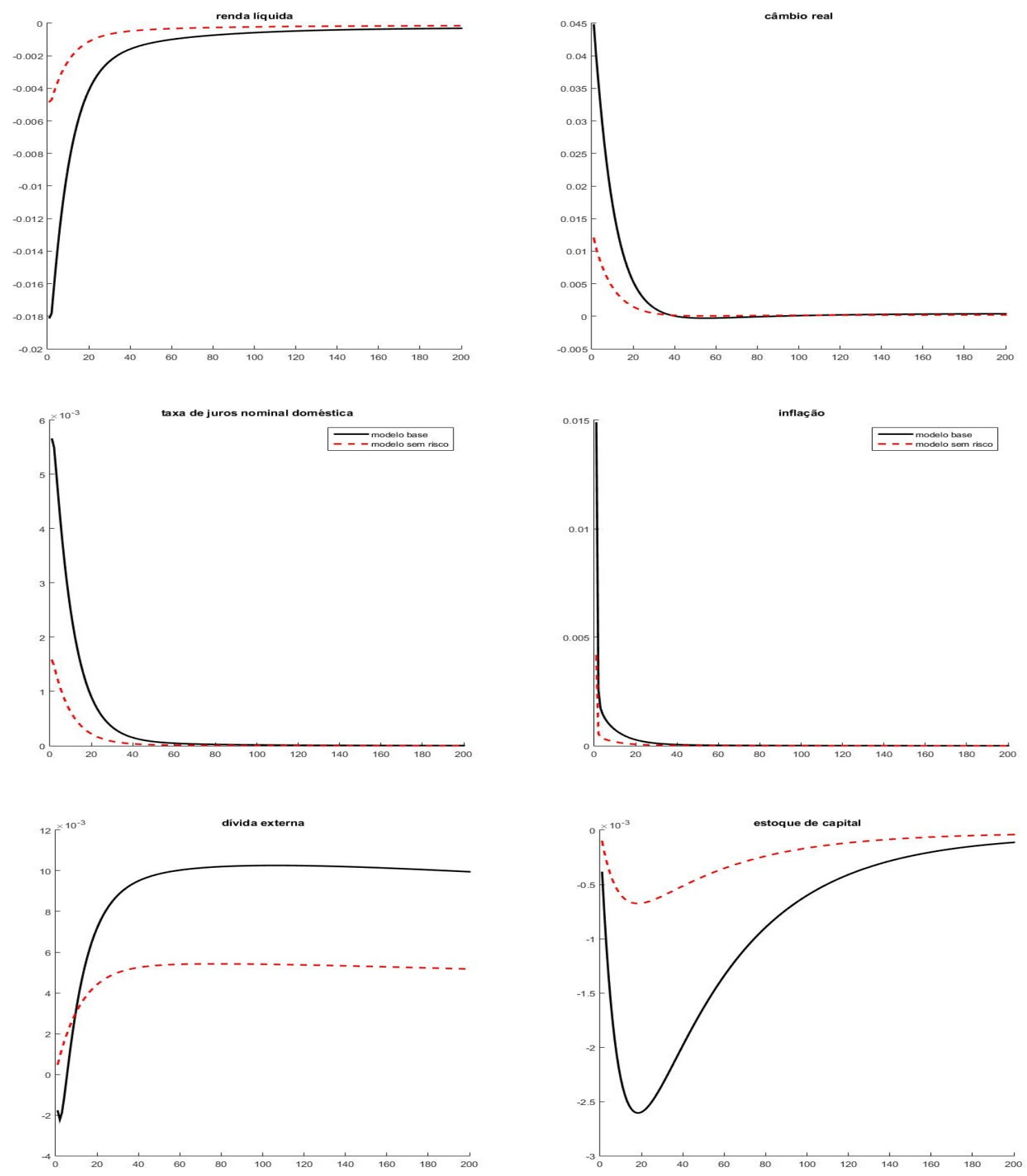

que:

$$
i_{t}-i=\left(1-\rho_{i}\right)\left[\omega_{\pi}(\pi-1)+\omega_{y}\left(\ln \left(Y^{p i b}\right)-\ln \left(Y^{n}\right)\right)\right]+\rho_{i}\left(i_{t-1}-i\right)+\varepsilon_{t}^{i}
$$

na qual, a autoridade monetária pondera desvios do PIB em relação ao seu valor no equilíbrio sem friç̧ões para a determinação da taxa de juros. Consideraremos $\omega_{y}=0.5$. Os resultados das duas políticas são análogos tanto para elevações da taxa de juros externa como para a retração da demanda global.

As figuras 18 e 19 mostram que, ao ser atingida por um choque externo, a economia na qual a 
Figura 15 - Ciclo Financeiro Global: Choque de - 1\% na demanda global
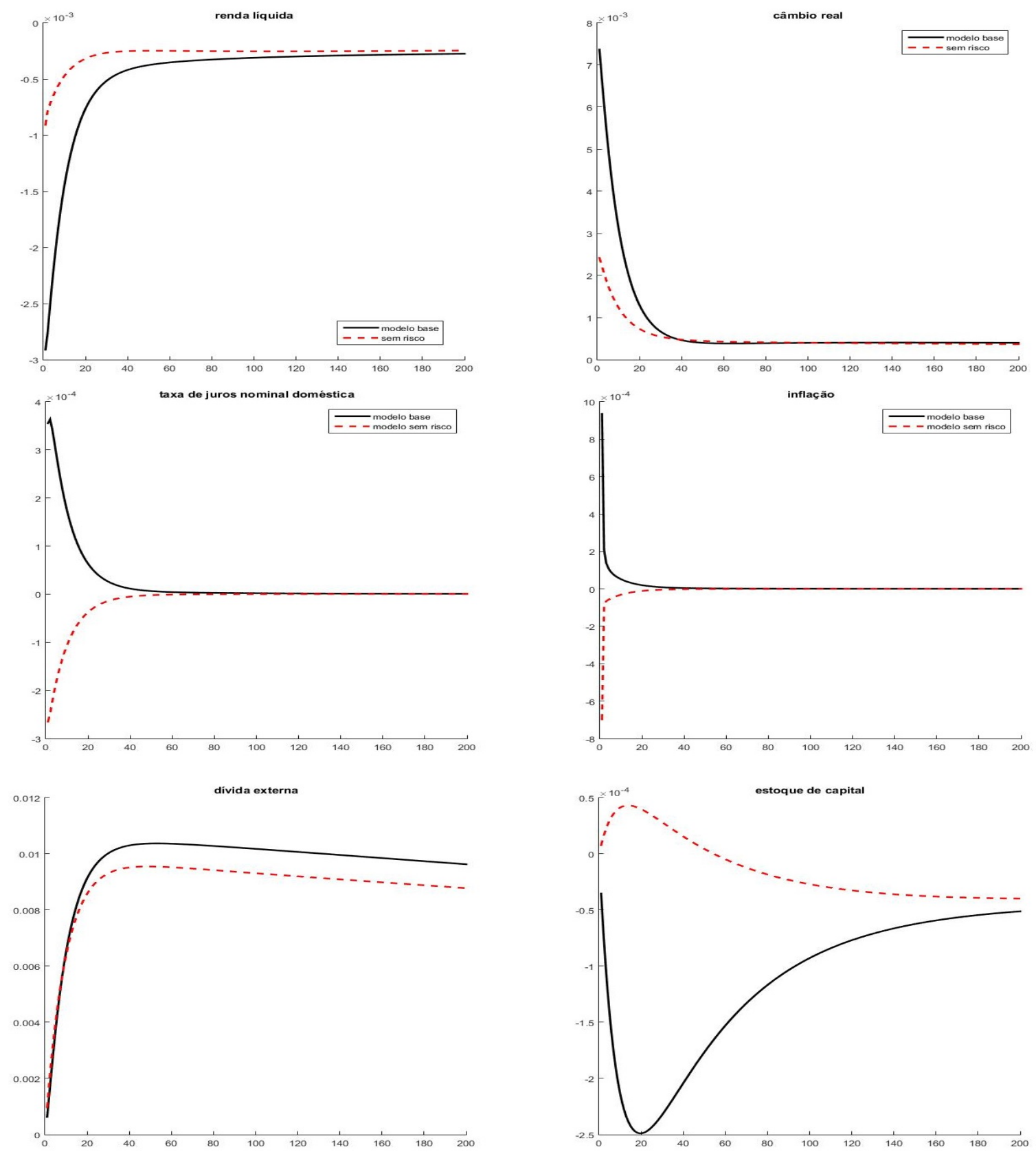

autoridade monetária reage menos à inflação (seja por um menor $\omega_{\pi}$ ou um $\omega_{y}$ positivo) sofre menos impactos recessivos. Diferentemente do exemplo dos preços rígidos, a formação de preços com base nas expectativas das firmas como descrito pela Curva de Phillips Novo Keynesiana (Equação 32) faz com que a inflação de fato suba mais como resposta a um choque externo, entretanto a resposta relativamente menor da autoridade monetária se traduz numa queda acentuada da taxa de juro real. Isso reduz significativamente o impacto no patrimônio líquido dos bancos e favorece o investimento em capital.

Indiscutivelmente, o aumento da inflação tem consequências econômicas e de bem-estar. De outro lado, os exemplos citados mostram que, para uma economia descrita por estas relações, uma autoridade 
Figura 16 - Rigidez de preços: Choque de 1\% na taxa de juros externa
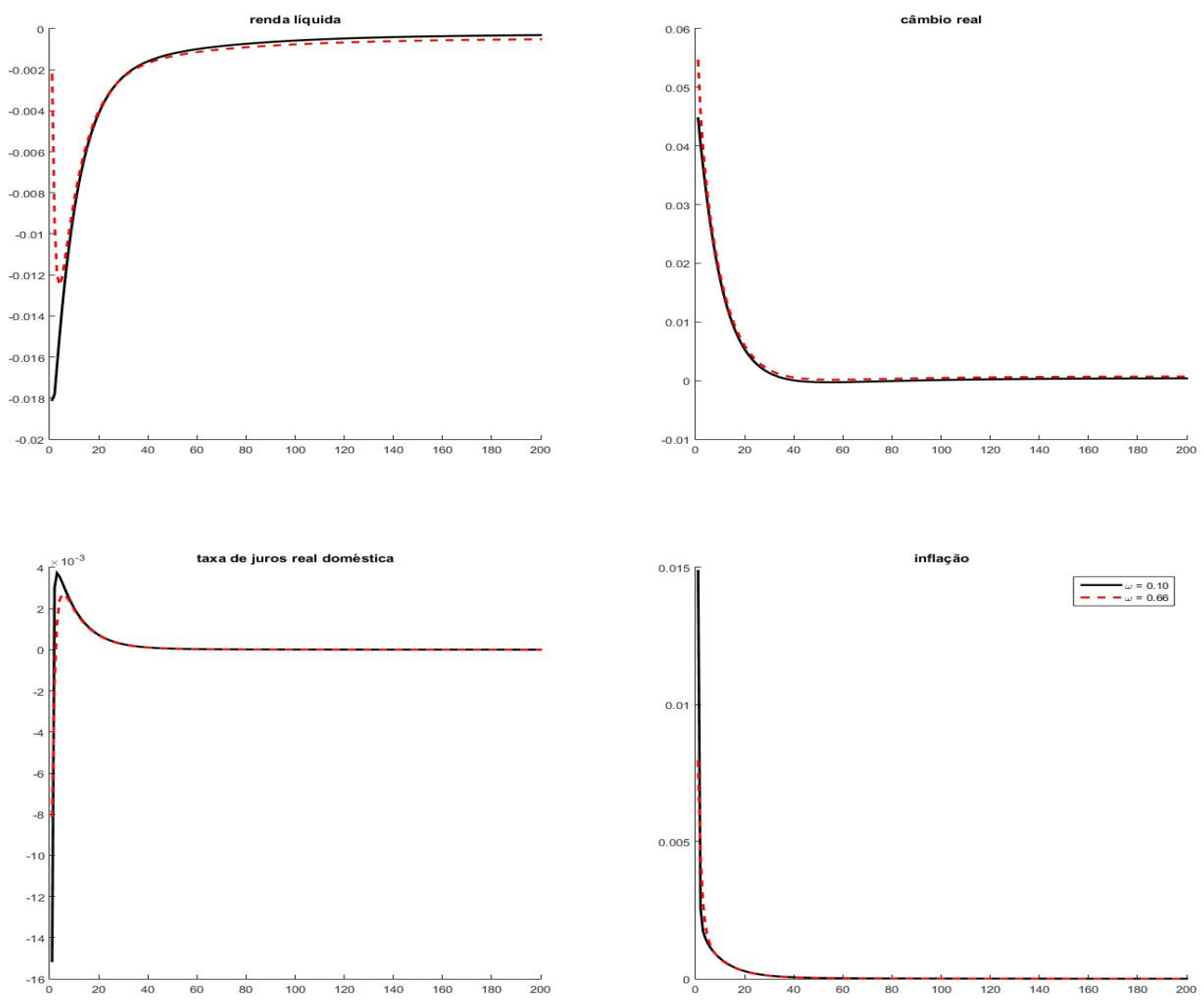

monetária mais leniente com a inflação pode assimilar melhor choques externos, independentemente do uso de medidas macroporudenciais alternativas.

\subsubsection{Controle de Capital e Medidas Macroprudenciais}

Especificações distintas da política monetária se mostraram efetivas para atenuar o impacto dos choques externos sobre, por exemplo, a renda nacional. Há na literatura um entendimento crescente de que medidas alternativas - costumeiramente unificadas sob o rótulo de políticas financeiras - podem ampliar a capacidade da autoridade monetária de assimilar perturbações externas. Em especial, consideraremos nesta seção dois tipos destas políticas que se apresentam no modelo na forma de $\tau_{t}^{d}$ e $\tau_{t}^{K}$. Da Equação 52 , percebemos que do ponto de vista do agente financeiro $\tau^{d}$ é uma taxa sobre o financiamento externo. Em sendo positiva, reduz a vantagem dos depósitos externos sobre os domésticos do ponto de vista do custo para o banco. Ou seja, $\tau_{t}^{d}>0$ diminui $\mu_{t}^{*}$ reduzindo a alavancagem dos bancos e o endividamento externo e pode ser entendida, portanto, como uma forma particular de controle de capital.

A existência de externalidades negativas do financiamento em moeda estrangeira não internalizadas pelos bancos domésticos neste modelo, abre espaço para uma melhora alocativa a partir de uma política financeira que mire neste ponto. Sob esta perspectiva, desejaríamos dispor de uma taxa que iniba o excesso de tomada de risco nos momentos de boom e atenue a queda da intermediação bancária na reversão. Ou seja, minimizar a volatilidade do crédito sem que com isso o torne excessivamente escasso. Dessa perspectiva, uma política cíclica que aja na contramão do efeito acelerador financeiro do modelo pode melhorar a resposta da economia diante de mudanças internacionais. 
Figura 17 - Rigidez de preços: Choque de - 1\% na demanda global
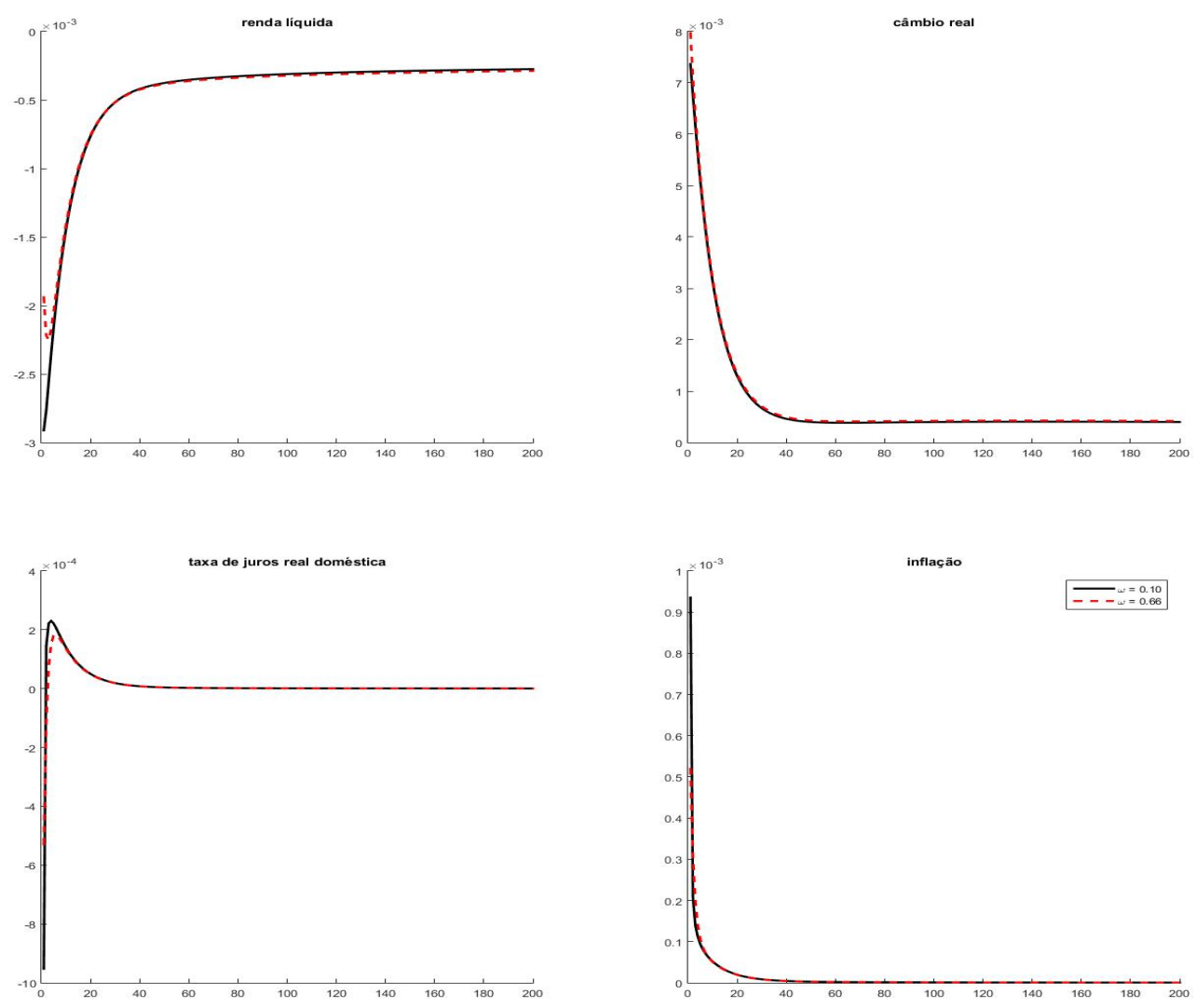

Seja $\tau_{t}^{d}$ tal que:

$$
\tau_{t}^{d}=\omega_{\tau^{d}}\left(\ln \left(K_{t}^{b}\right)-\ln \left(K^{b}\right)\right)
$$

em quem $\omega_{\tau^{d}}$ é um parâmetro positivo e $K^{b}$ é o valor de estado estacionário de capital em posse dos bancos. A taxa é tal que quando a quantidade de crédito bancário está acima do valor de equilíbrio ela se torna positiva, reduzindo a vantagem do financiamento externo. O fato da arrecadação gerada pela política ser revertida aos bancos sob a forma de subsídio ao patrimônio líquido implica que seu efeito é antes uma alteração de preços relativos internamente ao setor financeiro do que uma realocação de recursos entre setores econômicos. Da mesma forma, na reversão, esta política é um favorecimento do endividamento externo, ao ampliar a sua vantagem de custos em relação aos depósitos domésticos. Do ponto de vista matemático, age no sentido de minimizar a queda em $\mu_{t}^{*}$ promovida por uma aumento do prêmio de risco ou variação da taxa de juros internacional, favorecendo a retomada do endividamento externo.

A figura 20 mostra de que maneira algumas variáveis econômicas reagem a um choque de $1 \%$ no juros internacional sob a presença do controle de capital descrito acima para o caso em que $\omega_{\tau^{d}}=0.1$. A queda do patrimônio líquido dos bancos promovida pela desvalorização cambial associada ao aumento da taxa cobrada sobre os empréstimos internacionais, desencadeia uma redução na intermediação bancária $K_{t}^{b}$. Neste momento, $\tau^{d}$ se torna menor do que zero, representando um incentivo ao endividamento externo, mesmo frente ao aumento de custos, o que amplia a dívida externa e é por meio deste mecanismo que se atenua a desvalorização cambial e a consequente recessão econômica. Além disso, o menor impacto 
Figura 18 - Menor aversão à inflação: Choque de 1\% na taxa de juros externa
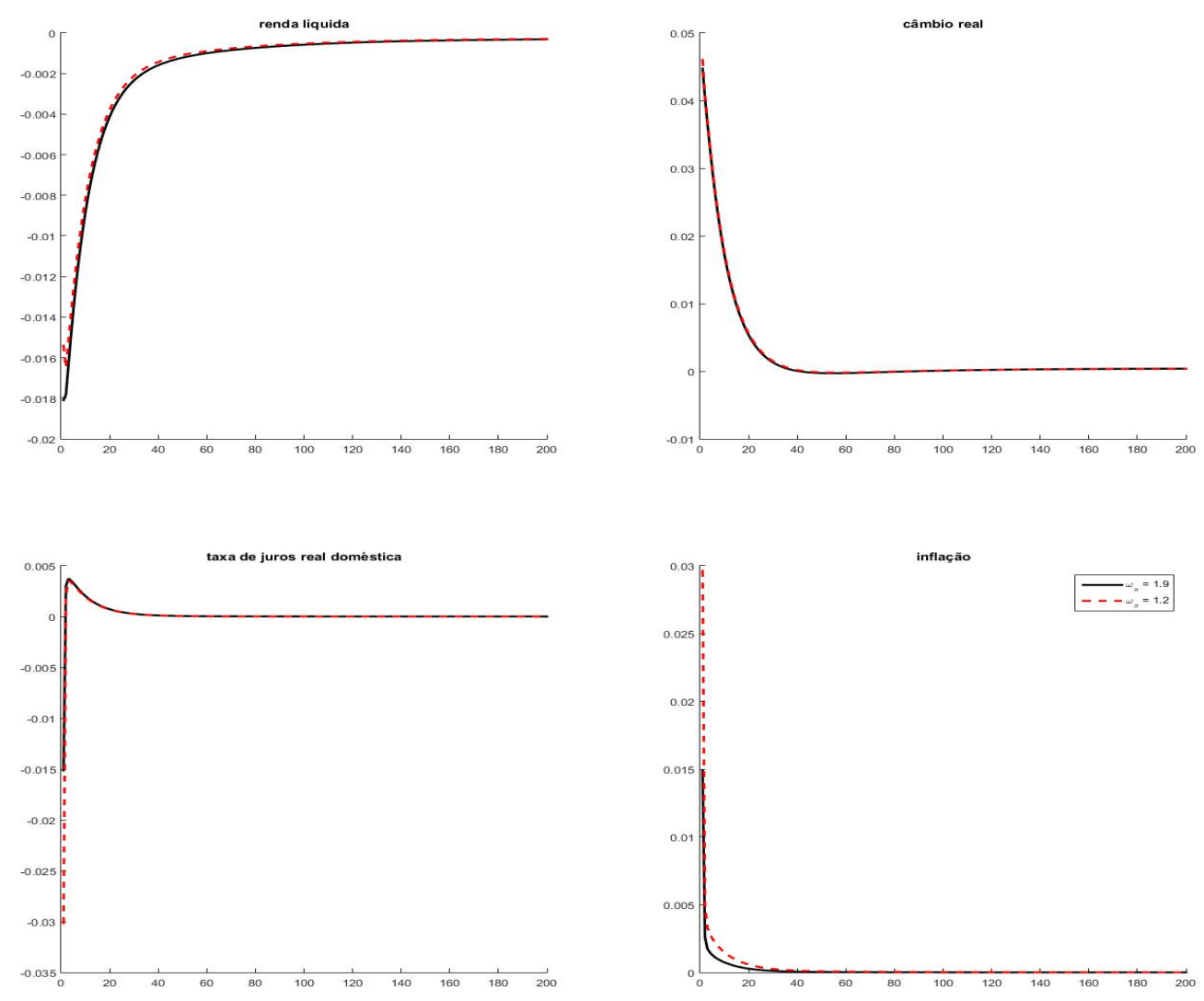

inflacionário permite uma reação menos agressiva da política monetária, representada na imagem pela escalada pós queda do juro real mais baixa do que no cenário base, atenuando os efeitos depressivos da perturbação. Ao se utilizar da política financeira, a política monetária dispõem de um instrumento adicional que amplia sua autonomia de reposta aos choques externos.

Parte importante do ajuste garantido pelo controle de capital ocorre via ampliação do endividamento externo em meio a uma elevação de seu custo. Este fato, evidentemente tem consequências de médio e longo prazo, como fica nítido nas funções impulso resposta, nas quais, seguindo o padrão, a linha tracejada vermelha representa o cenário sob a política, enquanto a linha preta descreve o modelo base. A elevação da dívida em um momento em que seu custo também cresce faz com que ela se estabilize num patamar bastante acima daquele na qual permanece sem a política. De tal forma que se no exemplo da maior rigidez de preços as firmas incorporavam a maior parte do choque, neste caso o setor financeiro é incentivado pela redução em $\tau^{d}$ a acomodar a escassez de divisas originada na elevação da taxa de juros externa.

Conforme volta a subir a intermediação bancária com a dissipação dos primeiros efeitos da choque, diminui a distância de $K_{t}^{b}-K^{b}$, tornando côncava a curva da dívida externa. A alta dependência de trajetória da dívida, entretanto, faz com que ela se acomode em um patamar permanentemente mais elevado, o que exige uma taxa de câmbio desvalorizada e aprofunda o efeito da queda do investimento na manutenção de um nível mais baixo de produção de capital e por consequência na renda. Pensando de maneira mecânica, o controle de capital é uma boa ferramenta para evitar a queda, mas não é suficiente para garantir a subida. 
Figura 19 - "Duplo mandato": Choque de - 1\% na demanda global
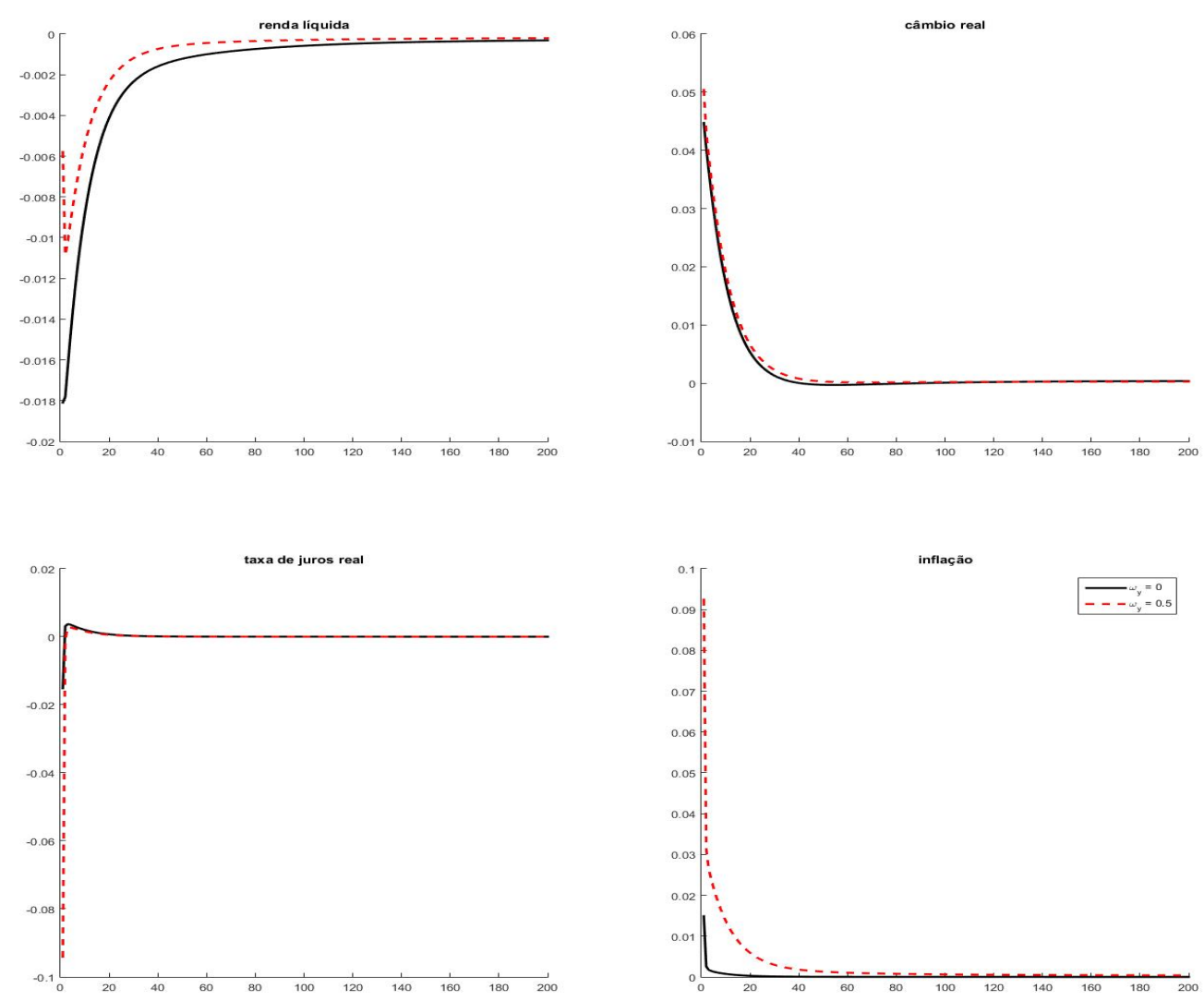

Evidentemente, toda esta análise é feita sob a hipótese de que nenhum outro choque atinja a economia neste período. Do contrário, poderíamos ter, no momento em que a economia começa a se estabilizar neste patamar de dívida mais alta e estoque de capital mais baixo, um choque positivo de produtividade que servisse para puxar a atividade de volta para cima. Para não discutir apenas aleatoriedades, outra medida possível, considerando o caráter novo keynesiano do modelo, seria o uso de política fiscal para dar tração à economia e retornar ao patamar de equilíbrio. A interação entre política fiscal e políticas financeiras é um tema pouco debatido na literatura e este simples exemplo mostra que há, pelo menos do ponto de vista teórico, espaço para uma coordenação frutífera entre elas.

Atendo-nos às políticas existentes no modelo, $\tau_{t}^{K}$ é o outro instrumento disponível para a realização de intervenções econômicas. Diferentemente de $\tau_{t}^{d}, \tau_{t}^{K}$ representa na Equação 52 uma redução do spread entre investimento em capital e os depósitos bancários. Em sendo positiva, portanto, esta taxa desincentiva a intermediação bancária e por isso é entendida em muitos modelos como um requisito sobre o capital do setor financeiro. Ela é, por construção, menos eficiente que $\tau_{t}^{d}$ na acomodação de um choque externo, ainda mais se modelada a partir da diferença entre o crédito bancário vigente e o de equilíbrio. Entretanto, ao contrário de $\tau_{d}$, por agir diretamente na vantagem ao investimento em capital, ela consegue servir de impulso para a retomada econômica. Como observado, o maior óbice ao retorno da economia para o equilíbrio no exemplo anterior é a explosão da dívida externa provocada pela combinação da elevação do custo com o incentivo ao endividamento do controle de capital. 
Figura 20 - Controle de Capital $\left(K^{b}\right)$ : Choque de $1 \%$ na taxa de juros externa
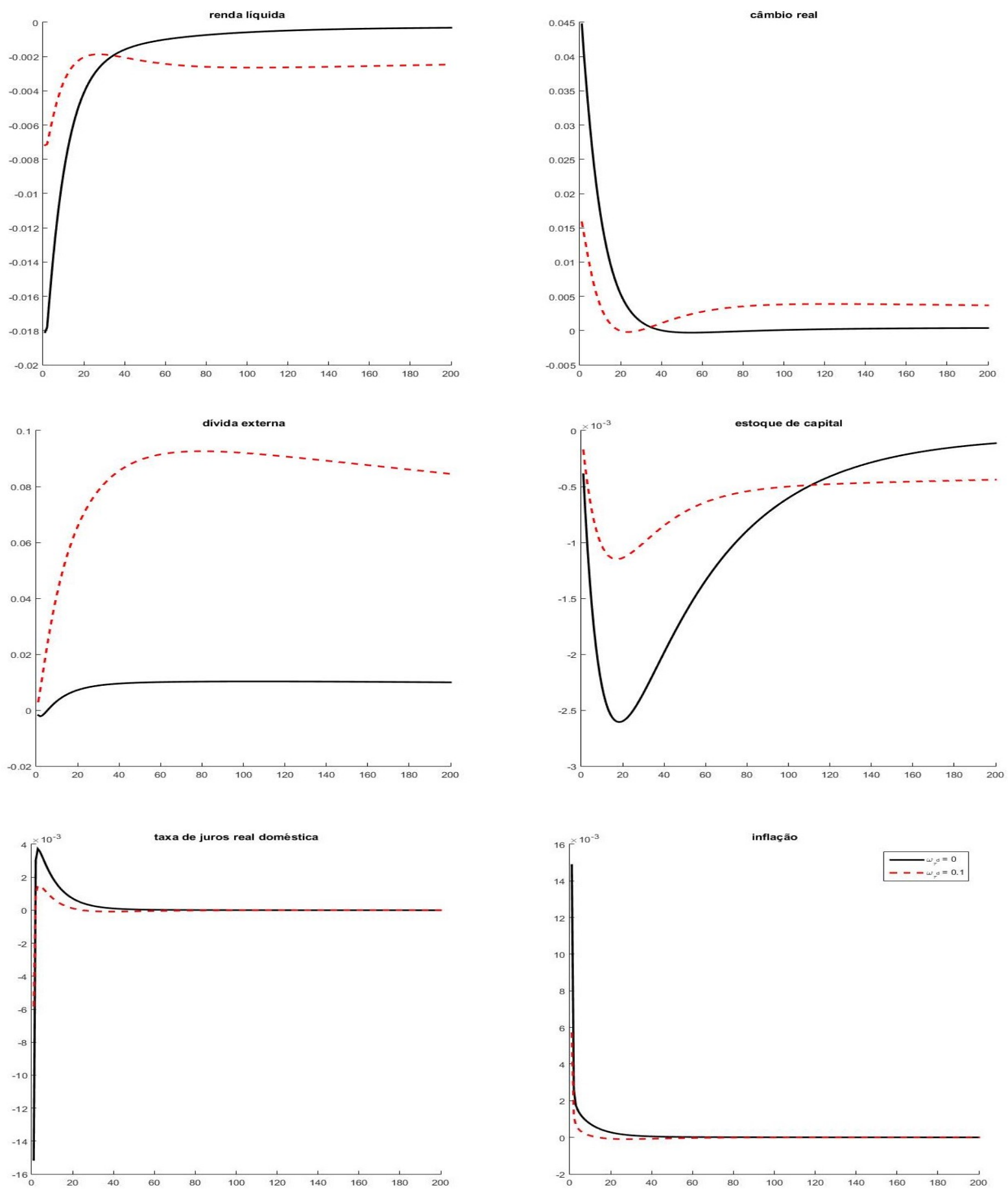
Seja $\tau_{t}^{K}$ tal que:

$$
\tau_{t}^{K}=\omega_{\tau^{K}}\left(\ln \left(D^{*}\right)-\ln \left(D_{t}^{*}\right)\right)
$$

sendo $\omega_{\tau^{K}}>0$, a política age como um contrapeso ao endividamento externo. Quando há um sobre-endividamento, a diminuição de $\tau_{t}^{K}$ incentiva um aumento da intermediação bancária, o que eleva o preço do capital (equity), iniciando um ciclo de boom e elevação do patrimônio líquido dos bancos. A demanda por crédito também pressiona o juro real para cima e é rapidamente atendida via uma ampliação da oferta de depósitos domésticos e, com a expectativa de valorização cambial motivada pelo crescimento da dívida externa, se inicia uma recomposição do balanço dos bancos. A figura 21 mostra a reação da economia, em comparação com o modelo base, a um choque da taxa internacional na presença dos requisitos de capital, para $\omega_{\tau^{K}}=0.2$. Ou seja, a cada $1 \%$ de aumento do endividamento externo acima do seu valor de equilíbrio a taxa sobre capital retraí-se em $0.2 \%$.

Em um primeiro momento, por desincentivar o endividamento externo, esta política não acomoda tão bem a perturbação externa. O câmbio se desvaloriza um pouco mais e a queda do produto é ligeiramente maior. Entretanto, conforme $D_{t}^{*}$ se eleva por conta do aumento da taxa de juros, $\tau_{t}^{K}$ se torna negativa, o que incentiva no médio prazo uma retomada mais expressiva da intermediação bancária fazendo com que, ao fim do processo, a economia retorne ao nível de equilíbrio da renda, da taxa de câmbio e do estoque de capital.

Há portanto, uma nítida simbiose entre os instrumentos avaliados nesta seção, de tal maneira que se torna lógica a tentativa de combinar as duas políticas, combinando assim o amortecimento imediato ao choque garantido por $\tau_{t}^{d}$ e uma reversão do endividamento externo motivado pela elevação de $\tau_{t}^{K}$. A combinação das duas de fato se mostra bastante efetiva, podendo assegurar, na métrica estabelecida por este trabalho, uma ampliação significativa da autonomia da política monetária da economia periférica. Constituindo um exemplo de que, ao menos teoricamente, há a possibilidade de que uma expansão dos instrumentos da política financeira do Estado assegurem menos e não mais distorções diante de um choque externo. A combinação das políticas não anula mutuamente as vantagens de cada uma, ao contrário, minimiza os efeitos colaterais. As figuras 22 e 23, mostram o resultado das simulações tanto para o choque internacional de juros como de demanda. Selecionou-se para este experimento os valores de $\omega_{\tau^{d}}=0.18 \mathrm{e}$ $\omega_{\tau^{K}}=0.2^{9}$. As funções impulso resposta mostram a simbiose mencionada.

No que se refere ao choque de juros, a desvalorização do câmbio desencadeia o processo recessivo convencional via patrimônio líquido dos bancos, o que ativa a política de controle de capitais mediante à queda em $K_{t}^{b}$, dando início a uma elevação da dívida externa tanto pelo efeito do juros como pelo favorecimento a este tipo de recurso motivado pela política financeira. A elevação inicial de $D_{t}^{*}$ encontra respaldo na política macroprudencial que alivia à restrição sobre posse de capital conforme a dívida cresce. Esse processo incentiva ainda mais a intermediação bancária o que faz com que o valor mínimo do estoque de capital seja maior neste caso, associado a um investimento que também cai menos. Todo este processo, garante simultaneamente uma menor queda da renda, do nível de consumo e também de poupança das famílias. A recuperação rápida do produto, incentiva ainda mais a intermediação bancária. A convergência da taxa de juros internacional motiva também a expectativa de apreciação cambial o que, junto da diminuição de $\tau_{t}^{d}$ por conta da retomada da intermediação bancária, faz com que a dívida externa diminua consistentemente. Diante disso, os bancos passam a utilizar mais depósitos bancários, o que explica o juro real doméstico momentaneamente acima do valor do modelo base, e em especial o seu patrimônio líquido que foi menos afetado pela crise e largamente favorecido por um aumento mais rápido

\footnotetext{
${ }^{9}$ esta seleção foi feita com base em uma análise de otimização de bem-estar apresentada pelo Apêndice E
} 
Figura 21 - Requisito de Capital $\left(D^{*}\right)$ : Choque de $1 \%$ na taxa de juros externa
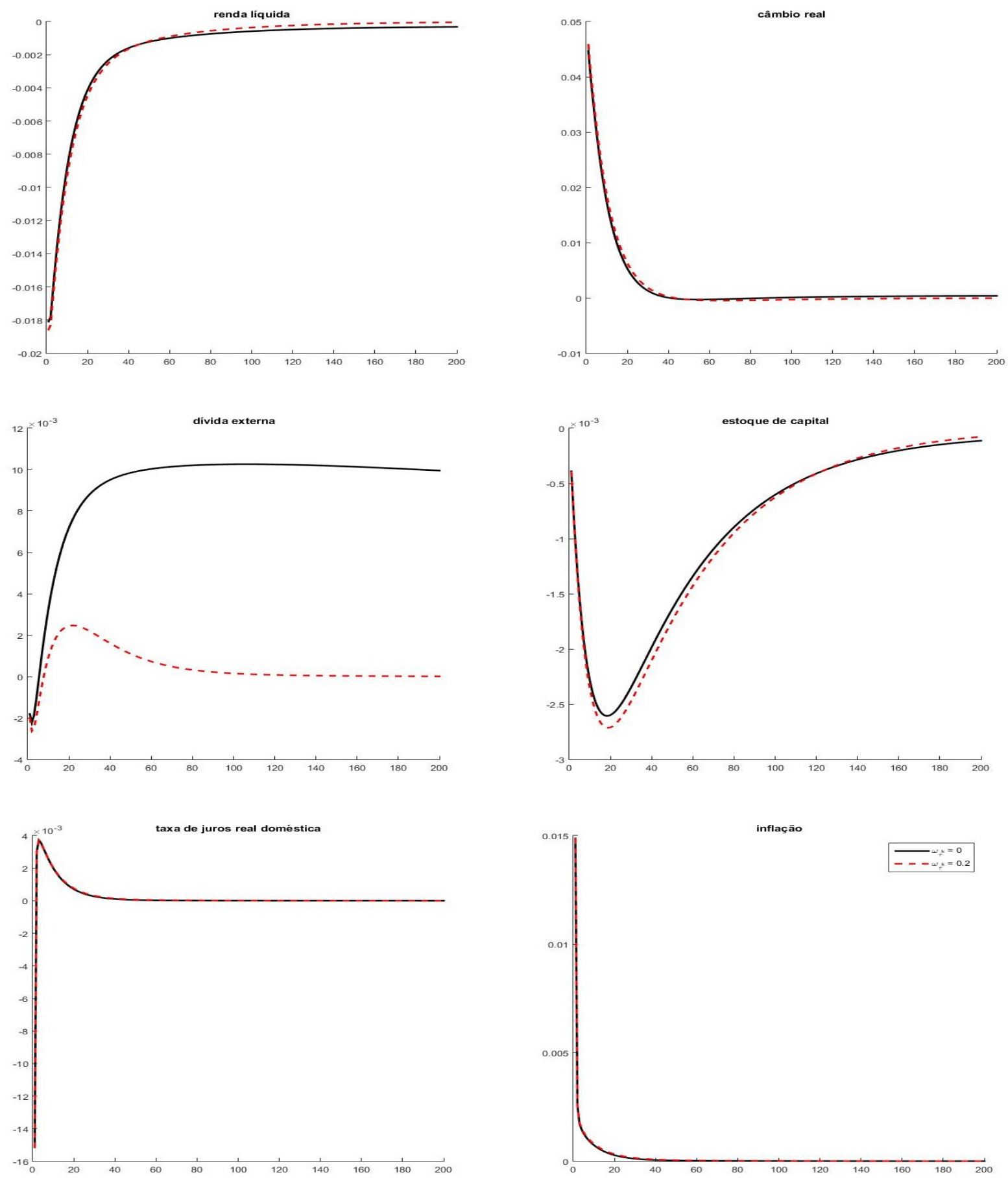
Figura 22 - Medidas Combinadas: Choque de 1\% na taxa de juros externa
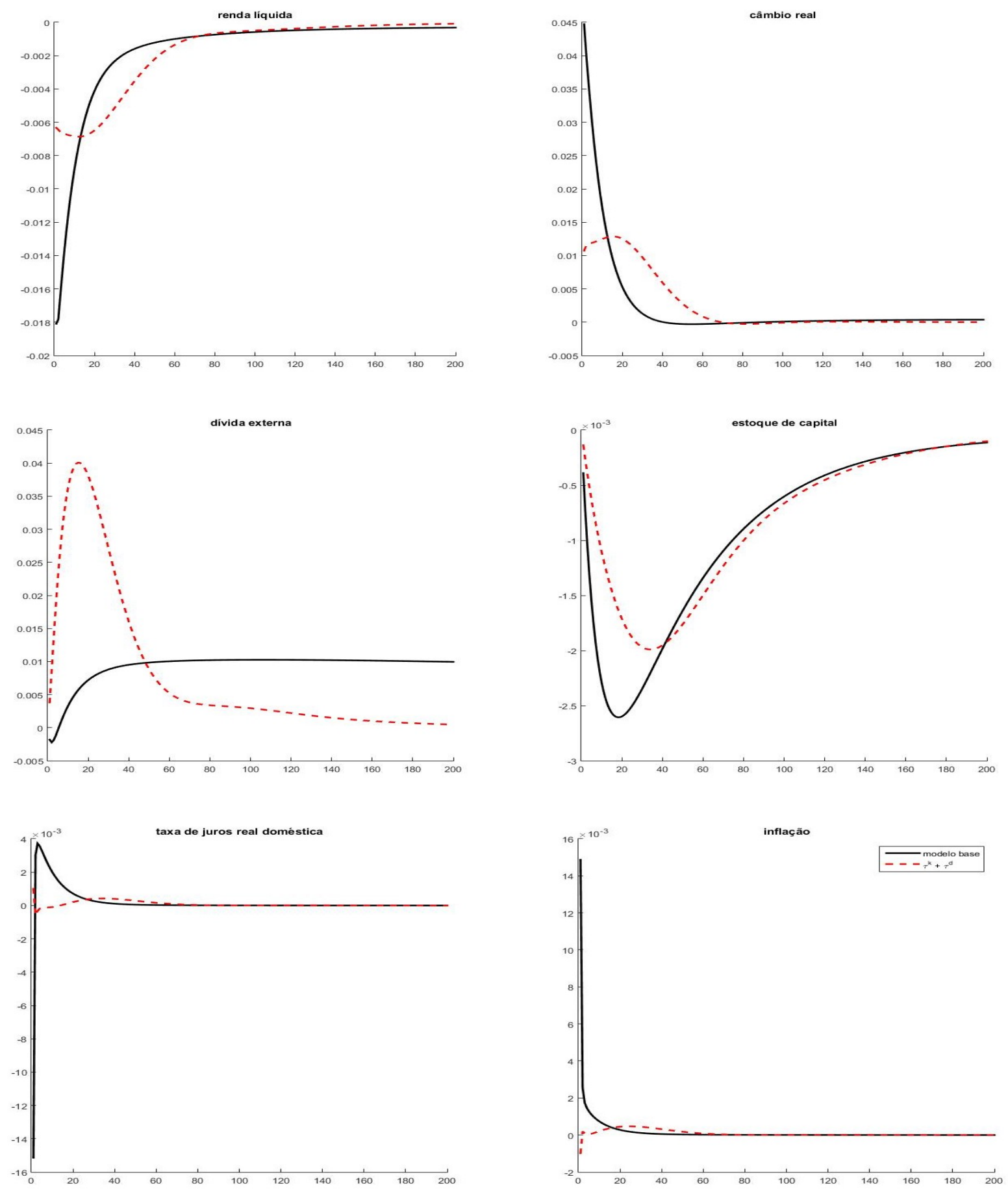

da remuneração do capital $Q_{t}$, motivado pela política $\tau_{d}^{K}$. Ao todo, a recessão foi menor em dimensão e duração.

O efeito da combinação de políticas diante de um choque da demanda externa é também significativo. A redução da demanda via diminuição das exportações e do produto combinada com uma amenização significativa da depreciação cambial gera uma deflação na economia. A conseguinte elevação brusca do juro real torna as famílias menos propensas a poupar na forma de capital e diminui a oferta de crédito por parte dos bancos ao reduzir o spread, o que explica a queda mais substancial do estoque de 
Figura 23 - Medidas Combinadas: Choque de - 1\% na demanda global
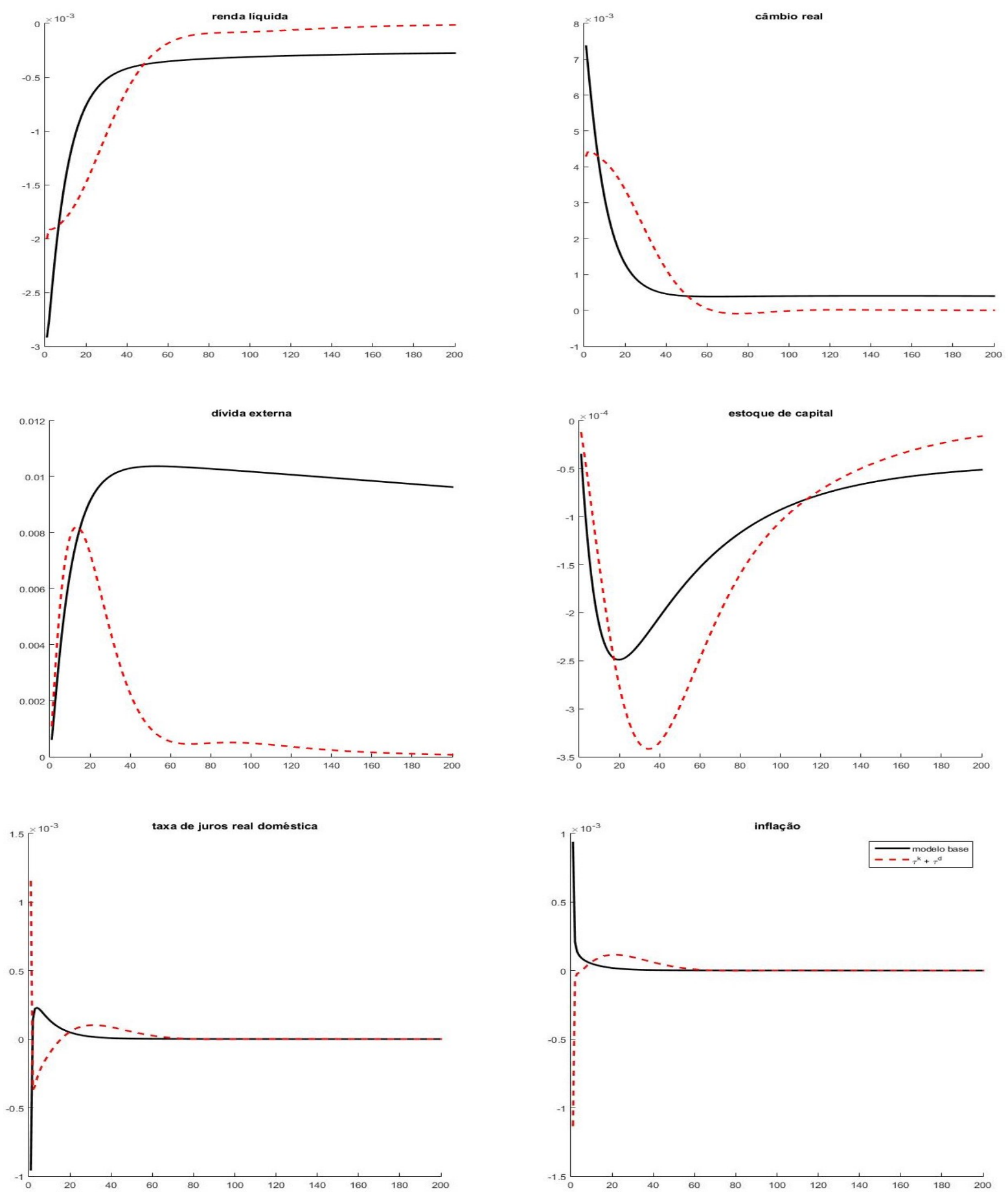

capital. Entretanto, conforme os instrumentos de política financeira engrenam, eleva-se a intermediação bancária e o processo de recuperação se inicia. Há uma elevação do preço de equity, um aumento nas exportações líquidas por conta da apreciação mais lenta do câmbio e uma retomada da atividade de tal forma que a economia retorna, em todas as dimensões analisadas, aos valores de equilíbrio.

A evidência empírica de um forte ciclo financeiro global, correlacionado com a política monetária do FED que impacta o prêmio de risco e os fluxos capitais aos países emergentes motiva a sugestão de Rey (2015) para que as autoridades monetárias adotem medidas adicionais caso almejem uma maior autonomia. 
Esta formalização teórica demonstra que combinações de medidas financeiras são de fato um possível caminho para a ampliação da autonomia em um regime de câmbio flutuante.

\subsection{Medindo a Autonomia da Política Monetária}

A avaliação dos custos e benefícios de políticas macroeconômicas, ao contrário de intervenções a um nível mais específico (micro), são de difícil mensuração, sendo tradicionais na literatura o uso de medidas de bem-estar. No que se refere a controles de capital e medidas macroprudenciais, há distintas formas de se medir bem-estar e, como discutido por Rebucci e Ma (2019), enquanto a maioria dos artigos teóricos busca uma política que eleve o nível de bem-estar do equilíbrio competitivo, uma alternativa é a definição da política ótima por meio da solução do problema de Ramsey. Outra maneira de conduzir a análise normativa é o que chamam de horse-racing, testando múltiplas alternativas em um modelo estrutural calibrado com base em evidências empíricas mais robustas. Algumas tentativas de mensuração de bem-estar são apresentadas no Apêndice E.

De toda maneira, medidas de bem-estar são sensíveis à maneira como se mede a própria variável, à forma funcional da utilidade e são lastreadas na hipótese forte de que a maximização do consumo intertemporal deve ser a métrica para a validade ou não de determinada política. A preocupação mais modesta desta pesquisa, inclusive diante da simplicidade das relações expressas por este modelo, é verificar se, do ponto de vista da autoridade monetária, em meio às distorções explicitadas e a escolha dos parâmetros, há combinações de políticas que ensejem uma maior autonomia tal qual definida no Capítulo 1. Esta seção avalia para diferentes combinações de parâmetros $\omega_{\pi}, \omega_{y}, \omega_{\tau^{d}}$ e $\omega_{\tau^{k}}$ distintas medidas de independência da autoridade monetária.

As próximas três subseções discutem alternativas de se mensurar a autonomia da política monetária, indo do caso mais específico ao mais geral ${ }^{10}$

\subsubsection{Capacidade de absorção do choque externo}

Em uma avaliação empírica, Zeev (2017) encontra que controles de capital aumentam a capacidade de absorção a um choque externo, medida como a transição da função impulso resposta estimada a partir dos dados. Uma maior autonomia, neste sentido, seria então obtida quão menor fosse a área descrita pela resposta a determinado choque externo. De tal maneira que o objetivo da autoridade monetária neste quesito seria:

$$
\min _{\omega_{\pi}, \omega_{y}, \omega_{\tau^{d}}, \omega_{\tau^{k}}} A b s_{i, j}^{\hat{\omega}}=\int_{0}^{\infty} F_{i, j}^{\hat{\omega}}(t) d t
$$

Em que $A b s$, medida de autonomia, é a integral do momento do choque até a sua dissipação, ou até o infinito, de $F_{i, j}^{\hat{\omega}}(t)$, que por sua vez é a função impulso resposta da variável $i$ diante de um choque de $j$ dado o conjunto de políticas $\hat{\omega}$ ao longo do tempo, $t$.

A Tabela 4 mostra a variação nesta medida de autonomia diante de um choque de juros externo em relação à renda líquida. A primeira linha indica o resultado do cenário base, a segunda linha mostra o valor de Abs para a combinação de políticas testada na seção anterior, por fim, na terceira linha, os

\footnotetext{
${ }^{10}$ Esta seção como um todo constitui um esforço original desta dissertação ao mesmo tempo que preliminar. Sem dúvidas um aprofundamento das vantagens e desvantagens de cada medida, bem como uma compreensão melhor da relação entre elas são necessárias para que se avance neste sentido.
} 
parâmetros da política foram escolhidos de acordo com a minimização descrita acima, isto é, são os valores de $\omega_{\tau^{d}}, \omega_{\tau^{k}}$ que minimizam esta integral específica. A Tabela 5 mostra o resultado para variações da inflação.

\begin{tabular}{|c|c|}
\hline Política & Abs \\
\hline$\omega_{\tau^{d}}=0, \omega_{\tau^{k}}=0$ & 0.3276 \\
\hline$\omega_{\tau^{d}}=0.18, \omega_{\tau^{k}}=0.2$ & 0.3269 \\
\hline$\omega_{\tau^{d}}=0.05, \omega_{\tau^{k}}=0.2$ & 0.3126 \\
\hline
\end{tabular}

Tabela 4 - Absorção a um choque de $1 \%$ na taxa anual de juros externa: renda líquida

\begin{tabular}{|c|c|}
\hline Política & Abs \\
\hline$\omega_{\tau^{d}}=0, \omega_{\tau^{k}}=0$ & 0.0275 \\
\hline$\omega_{\tau^{d}}=0.18, \omega_{\tau^{k}}=0.2$ & 0.0178 \\
\hline$\omega_{\tau^{d}}=0.28, \omega_{\tau^{k}}=0.1$ & 0.00007 \\
\hline
\end{tabular}

Tabela 5 - Absorção a um choque de $1 \%$ na taxa anual de juros externa: inflação

Podemos observar que em ambos os casos, a inclusão de medidas alternativas amplia a capacidade da autoridade monetária de absorver o choque externo de juros. Enquanto a política gera variações percentuais mais tímidas em relação à renda líquida, no caso da inflação a melhora é substantiva, em especial quando os parâmetros são escolhidos de maneira ótima. Observamos também, e isto é verificado para as diversas combinações de valores dos parâmetros, que neste caso $\tau^{d}$ menor e $\tau^{k}$ maior acomodam melhor as variações na renda, ao passo que o inverso é verdadeiro para o caso da inflação, indicando que as diferentes medidas desempenham papéis distintos na acomodação dos choques e que, de acordo com as preferências da autoridade monetária, há múltiplas maneiras de combiná-las.

A Tabela 6 por sua vez indica o resultado para alterações na aversão à inflação e na preocupação com variações da renda por parte da autoridade monetária. Os resultados indicam uma contradição entre os diferentes objetivos de estabilização da renda e da inflação, olhando sobre esta perspectiva de autonomia. Enquanto uma diminuição da aversão inflacionária e ponderação do produto geram ganhos substanciais na minimização do choque sobre a renda, muito maiores inclusive do que no cenário ótimo das medidas macroprudenciais descrito acima, há uma piora substancial na acomodação inflacionária. Esta ambiguidade é mantida para diferentes variações de parâmetros, o que é intuitivo.

\begin{tabular}{|c|c|c|}
\hline Variável de Interesse & Política & Abs \\
\hline $\ln \left(\mathrm{Y}^{l}\right)$ & $\omega_{\pi}=1.9, \omega_{y}=0$ & 0.3276 \\
\hline $\ln \left(\mathrm{Y}^{l}\right)$ & $\omega_{\pi}=1.5, \omega_{y}=0.5$ & 0.0571 \\
\hline$\pi$ & $\omega_{\pi}=1.9, \omega_{y}=0$ & 0.0275 \\
\hline$\pi$ & $\omega_{\pi}=1.5, \omega_{y}=0.5$ & 0.539 \\
\hline
\end{tabular}

Tabela 6 - Absorção a um choque de $1 \%$ na taxa anual de juros externa: diferentes parâmetros da autoridade monetária 


\subsubsection{Minimização da função perda: choques externos}

À luz da discussão anterior, maneiras alternativas de conduzir a política monetária devem ser avaliadas em conjunto, uma vez que diante de um choque de juros externo, por exemplo, podem ser eficientes para aliviar os impactos recessivos sobre o produto, ao mesmo tempo que ampliam o choque inflacionário. Seguindo a intuição de Davis e Presno (2017), estabelecemos uma função-perda para a autoridade monetária que determinará o conjunto de parâmetros $\omega_{\pi}, \omega_{y}, \omega_{\tau^{d}}$ e $\omega_{\tau^{k}}$ que minimizam o custo das oscilações econômicas do ponto de vista do Banco Central. De tal forma que o problema da autoridade monetária torna-se:

$$
\min _{\omega_{\pi}, \omega_{y}, \omega_{\tau^{d}}, \omega_{\tau^{k}}} L=\mathbb{E}_{0} \sum_{t=0}^{\infty} \beta^{t}\left[(\pi-1)^{2}+\alpha_{y}\left(\ln \left(Y^{p i b}\right)-\ln \left(Y^{n}\right)\right)^{2}\right]
$$

Em que $L$ designa o valor presente esperado da soma dos desvios da autoridade monetária de seus objetivos e $\alpha_{y}$ é um parâmetro positivo. Para toda a análise subsequente consideraremos $\alpha_{y}=1$. Vale observar que esta hipótese é diferente e não implica necessariamente em $\omega_{y}>0$. Ao contrário, um regime de metas de inflação estrito $\left(\omega_{\pi}>>0\right.$ e $\left.\omega_{y}=0\right)$, mesmo na presença de fricções, pode alcançar simultaneamente a meta da inflação e do produto (divine coincidence). A ponderação positiva e simétrica entre inflação e renda na função-perda implica apenas que, na avaliação da efetividade da autoridade monetária, estas duas variáveis são levadas em consideração na mesma medida.

Nesta subseção, entretanto, ao invés de considerar a economia completa, isto é, sujeita também aos choques domésticos de juros e produtividade, restringiremos a análise ao caso em que o país emergente é atingido só por choques externos, $L_{e x}$. Há duas motivações para esta formatação. A primeira é supor que há casos de economias pequenas e abertas em que as oscilações externas constituem o principal desafio das autoridades monetárias. A segunda é entender a melhor combinação de medidas, mesmo em uma economia com choques domésticos expressivos, caso o objetivo da autoridade monetária com tais políticas seja ampliar, exclusivamente, a sua independência do setor externo.

Para determinar o valor dos parâmetros, conduzimos uma otimização numérica da esperança da função-perda em uma aproximação de segunda ordem da resolução do modelo e condicional a estarmos no estado estacionário em que novos choques são previstos ${ }^{11}$. Isto é, a média ergódica de $L$ em um mundo em que a variância importa e dado que a economia se encontra no estado estacionário não-estocástico.

A Tabela 7 mostra os resultados dos experimentos conduzidos com distintas restrições sobre a política monetária. A primeira linha indica o cenário base. Na segunda, todos os parâmetros são fixados em zero menos a aversão do Banco Central à inflação que pode variar. Na tabela é reportado o valor observado sob estas condições, indicando que, ao levar em consideração os impactos sobre produto e renda dos choques externos, ser mais leniente com a inflação é uma política ótima. Ao permitir que a regra de Taylor possua um parâmetro positivo para os desvios do produto, $\omega_{\pi}$ aumenta ligeiramente e observamos uma melhora significativa na perda esperada, ou, nos termos deste trabalho, na autonomia da política monetária, mesmo sem a utilização de nenhuma medida macroprudencial.

\footnotetext{
${ }^{11}$ Como argumentam Aoki, Benigno e Kiyotaki (2016) esta definição é um tanto paradoxal. Os agentes estão no estado estacionário e, por serem racionais, antecipam choques futuros na economia, entretanto, ironicamente, os choques nunca ocorrem.
} 


\begin{tabular}{|c|c|}
\hline Política & $L_{e x}$ \\
\hline$\omega_{\pi}=1.9, \omega_{y}=0, \omega_{\tau^{d}}=0, \omega_{\tau^{k}}=0$ & 0.3696 \\
\hline$\omega_{\pi}=1.1, \omega_{y}=0, \omega_{\tau^{d}}=0, \omega_{\tau^{k}}=0$ & 0.1956 \\
\hline$\omega_{\pi}=1.6, \omega_{y}=0.7, \omega_{\tau^{d}}=0, \omega_{\tau^{k}}=0$ & 0.00159 \\
\hline$\omega_{\pi}=\infty, \omega_{y}=0, \omega_{\tau^{d}}=0.3, \omega_{\tau^{k}}=0.3$ & 0.0060 \\
\hline$\omega_{\pi}=2.7, \omega_{y}=1.9, \omega_{\tau^{d}}=0.01, \omega_{\tau^{k}}=0.01$ & 0.0001165 \\
\hline
\end{tabular}

Tabela 7 - Autonomia da autoridade monetária: choques externos

As linhas subsequentes indicam os resultados quando se utilizam políticas alternativas. A quarta linha mostra que para valores elevados dos parâmetros da política financeira observa-se que $\omega_{\pi}$ e $\omega_{y}$ ótimos reproduzem um resultado usual da literatura: ao serem inclú́dos controle de capital e medida macroprudencial a política monetária pode se dedicar exclusiva e rigorosamente ao objetivo de minimização inflacionária. Este resultado também é observado por Davis e Presno (2017) e Aoki, Benigno e Kiyotaki (2016), sendo que neste último o teste é para variações do bem-estar. A última linha indica o resultado de uma otimização em que todos os parâmetros podem variar indiscriminadamente até que se atinga o $L_{e x}$ ótimo. O resultado indica que medidas macroprudenciais modestas permitem uma ponderação maior na Regra de Taylor para os desvios da inflação e, se somadas a uma ponderação relativamente grande dos desvios do produto, garantem de fato uma diminuição substantiva da perda esperada da autoridade monetária em relação ao cenário base.

\subsubsection{Minimização da função perda: caso geral}

A atuação cotidiana da autoridade monetária não se restringe a um tipo de choque específico e tampouco é possível ajustar continuamente políticas a depender do tipo de perturbação do momento. Neste sentido, uma política que busque maior autonomia deve garantir que em face dos choques diversos ao qual a economia doméstica está submetida, os custos associados a estes choques sejam coletivamente minimizados por uma coordenação dos instrumentos disponíveis. Nos termos do debate do Capítulo 1, enseja maior autonomia de política monetária um arranjo que entregue de maneira mais eficiente o equilíbrio externo e interno. Traduzindo para o debate deste capítulo,e em especial desta seção, isso implica minimizar $L$ no cenário em que todos os choques são previstos.

O mesmo mecanismo de otimização empregado na subseção anterior corresponde, neste caso, aos resultados exibidos na Tabela 8 . As três primeiras linhas seguem precisamente a mesma lógica do que foi discutido em relação à Tabela 7 , com o destaque importante de que, ao estar sujeita a choques de produtividade, a autoridade monetária diminui menos a aversão à inflação no caso descrito pela $2^{\text {a }}$ linha, e eleva substancialmente este mesmo parâmetro quando acompanhada de um $\omega_{y}>0$. 


\begin{tabular}{|c|c|}
\hline Política & $L$ \\
\hline$\omega_{\pi}=1.9, \omega_{y}=0, \omega_{\tau^{d}}=0, \omega_{\tau^{k}}=0$ & 0.4106 \\
\hline$\omega_{\pi}=1.5, \omega_{y}=0, \omega_{\tau^{d}}=0, \omega_{\tau^{k}}=0$ & 0.3802 \\
\hline$\omega_{\pi}=3.1, \omega_{y}=0.7, \omega_{\tau^{d}}=0, \omega_{\tau^{k}}=0$ & 0.3127 \\
\hline$\omega_{\pi}=\infty, \omega_{y}=0, \omega_{\tau^{d}}=0.24, \omega_{\tau^{k}}=0.08$ & 0.47 \\
\hline$\omega_{\pi}=1.1, \omega_{y}=0.3, \omega_{\tau^{d}}=0.6, \omega_{\tau^{k}}=0.6$ & 0.1566 \\
\hline
\end{tabular}

Tabela 8 - Autonomia da autoridade monetária: caso geral

Diante da não optimalidade, neste cenário, de um regime de metas estrito, a quarta linha apresenta as medidas macroprudencias ótimas tais que $\omega_{\pi}=\infty$ e $\omega_{y}=0$. Os resultados indicam que, considerando a economia completa, por conta do viés inflacionário e das dimensões financeiras contracionistas dos choque externos, em nenhum cenário é vantajoso possuir uma aversão absoluta à inflação, ao contrário do que é argumentado na literatura. Uma autoridade monetária rigorosa no combate à inflação ocasiona maiores perdas a ela própria ${ }^{12}$.

Por fim, a livre otimização dos parâmetros indica que medidas macroprudenciais significativas fazem as vezes da política monetária no sentido de que, acompanhadas de modestas aversão à inflação e ponderação do produto, são capazes de suavizar as oscilações econômicas de maneira eficaz. O motivo para este resultado é o caráter cíclico das políticas financeiras descritas nesta pesquisa. Sendo a atividade bancária, por seu elemento de acelerador financeiro, a grande responsável por propagar os diversos choques para toda a economia, medidas que atuem anticilicamente sobre o crédito e o endividamento externo são efetivas na garantia de uma maior eficácia e independência da política monetária. Ou seja, o que historicamente é atribuído exclusivamente ao câmbio flutuante, é melhor observado, neste caso específico, com a coordenação entre este regime cambial, uma política monetária mais leniente com a inflação e instrumentos financeiros.

\subsection{Conclusão}

O esforço analítico realizado neste capítulo buscou construir uma dimensão tratável e formalizada das evidências empíricas e dos debates teóricos organizados pelo Capítulo 1 e retomados pelo Capítulo 2. A principal distinção entre o modelo desenvolvido aqui e aquele no qual se inspira é o que se responde com este mesmo ferramental. O eixo da investigação é compreender de que maneira um conjunto de políticas disponíveis às autoridades monetárias dos países periféricos pode elevar sua independência de ação diante de uma perturbação externa. Observa-se que medidas que atuem no sentido de suavizar a reação da política monetária a um choque externo representam uma atenuação dos efeitos recessivos destas perturbações. Notadamente, a operacionalidade do regime de metas de inflação atribuí maiores dificuldades para a garantia de autonomia da política monetária. Em linha com o que a literatura tem encontrado para este tipo de modelo, atesta-se que instrumentos de política financeira e macroprudencial que garantem a internalização das externalidades associadas ao endividamento em moeda estrangeira melhoram a resposta econômica diante de mudanças do cenário externo.

\footnotetext{
${ }^{12}$ Este resultado são robustos à variações de $\alpha_{y}$, em particular, apenas para $\alpha_{y}<0.2$ se observou uma melhora, em relação ao cenário base, de uma rigor absoluto com a inflação
} 
O prêmio de risco endógeno às condições de liquidez internacional representa uma fonte adicional de volatilidade para a economia periférica, ampliando a dimensão e a persistência dos choques externos, o que amplia o efeito positivo de uma coordenação entre política monetária convencional e outras medidas alternativas. O impacto da demanda internacional na percepção de risco dos agentes, motivando uma corrida pela liquidez, aprofunda as contradições enfrentadas pela autoridade monetária do país emergente.

Por serem fatores de substantiva oscilação econômica, uma melhor especificação das origens e racionalidades dos fluxos internacionais de capital permitiria uma compreensão mais ampla dos custos e benefícios associados a diferentes políticas. Uma limitação do modelo é justamente que toda movimentação de capital entre fronteiras é determinada pela maximização do setor financeiro doméstico. Seria interessante acrescentar uma formalização para o comportamento dos agentes externos que buscam, ao comprar ativos da economia doméstica, justamente retornos maiores e podem impor restrições/sair do mercado diante da adoção de controle de capitais ou de uma maior leniência com a inflação. Este tipo de interação certamente mereceria mais atenção. Um caminho potencial para pesquisas futuras é incorporar a rica discussão que Gabaix e Maggiori (2015) fazem sobre determinação da taxa de câmbio via interação entre operadores financeiros de dois países. 


\section{Considerações Finais}

Existe uma crescente preocupação na literatura de macroeconomia internacional com os efeitos e os canais de transmissão de política monetária entre países para além dos tradicionalmente observados. Grande atenção tem sido dada para entender de que maneira, ao ter seu papel garantido como país emissor da moeda de reserva internacional, a política do FED determina movimentos gerais de capital e condições financeiras por todo o mundo, independentemente do regime de câmbio. Adicionalmente, as diversas especificidades de economias emergentes também têm motivado, já há algum tempo, o desenvolvimento de modelos específicos que deem conta da heterogeneidade entre centro e periferia. $\mathrm{O}$ Capítulo 1 desta dissertação apresentou de que maneira se coloca contemporaneamente na literatura a questão da autonomia de política monetária para países emergentes. A partir de um levantamento teórico historicamente abrangente torna-se possível construir um conceito de autonomia monetária que abarque os acúmulos do pensamento econômico.

Utilizando-se de duas metodologias distintas e complementares, o Capítulo 2 e o Capítulo 3 mostram que negligenciar as inter-relações existentes entre a determinação do prêmio de risco e condições econômicas globais, bem como não considerar efeitos financeiros para análise da transmissão de política monetária podem acarretar um viés analítico relevante na análise de economias abertas. Em um arcabouço muito simples e direto, o Modelo Agregado antecipa boa parte das conclusões que obtivemos por meio do Modelo Novo Keynesiano. O primeiro, ao focalizar a minimização da função perda da autoridade monetária, mostra que a volatilidade gerada por oscilações cambiais em um contexto de financial spillovers, ciclo financeiro global e repasse cambial para os preços abre espaço para um ganho de autonomia da política monetária ao se coordenar política monetária e financeira. Neste cenário, reforça a tese de que, diante da integração financeira contemporânea, os resultados dos modelos canônicos exigem mais cautela.

O segundo modelo apresenta uma racionalidade aos transbordamentos financeiros em um contexto de equilíbrio geral dinâmico e estocástico. Tendo como base teórica a literatura sobre o "pecado original", o Modelo Novo keynesiano mostra que diante da não internalização por meio dos agentes financeiros do risco cambial agregado associado ao financiamento externo, a adoção de políticas macroprudenciais garante maior autonomia e eficácia da política monetária. Adicionalmente, o viés inflacionário dos choques externos contribui para acirrar os dilemas da autoridade monetária, indicando que uma maior leniência do Banco Central com a inflação seria potencialmente benéfica neste cenário.

Observa-se que o ganho de autonomia da política monetária, tal qual é definida aqui, indica que o câmbio flutuante por si só não é tão efetivo quanto se supõe para garantir eficácia da política monetária de uma economia doméstica emergente com mobilidade de capitais. Este resultado reforça uma análise de independência monetária que seja mais pautada em uma diferenciação entre níveis de autonomia e não de maneira dicotômica como tradicionalmente é feito. Do ponto de vista teórico, esta pesquisa mapeia os canais por meio dos quais este resultado estabelecido pelo arcabouço de Mundell-Fleming não se observa.

Historicamente, a constatação de que os fluxos de capital são coordenados internacionalmente apresentou a maior fonte de questionamento ao paradigma canônico, uma vez que este fato subjuga as autoridades monetárias da periferia aos movimentos financeiros do centro. Entretanto, o potencial contracionista de uma desvalorização cambial - tanto por seu impacto inflacionário como financeiro constituí, com base na avaliação feita por este trabalho, um elemento central para a não adequação de uma estrutura de tipo Mundell-Fleming. De tal forma que se o primeiro elemento foi suficiente para que se levantem suspeitas sobre a efetividade do ajuste cambial na garantia de autonomia da política monetária, 
o segundo coloca dúvidas sobre a compatibilidade de um regime de metas de inflação com o câmbio flexível na ausência de medidas macroprudenciais.

Diante da relativa simplicidade do Modelo Novo Keynesiano e da forma como foi especificado o prêmio de risco, esta análise já encontra uma limitação estrutural. Outra ressalva tem a ver com a não estimação dos parâmetros e a falta de embasamento empírico mais robusto para a calibragem, tal que os resultados obtidos, são, evidentemente, dependentes destas escolhas. Além disso, incorporar uma impossibilidade de se financiar investimento de longo prazo via depósitos domésticos, como discutido na literatura, também deve alterar parte dos resultados. Neste sentido, um controle de capitais que diferencia Investimento Externo Direto de fluxos de curto prazo é relevante. O comportamento da autoridade monetária também pode ser melhor avaliado. Em especial, caso ela utilizasse medidas de inflação que sejam menos sensíveis ao câmbio, a necessidade de medidas alternativas provavelmente diminuirá. Ao mesmo tempo, uma maior leniência com a inflação pode corroer a credibilidade do Banco Central e elevar o prêmio de risco do país. Outra limitação é a análise concentrada nos controles de capital. Como discutido no Capítulo 1, acúmulo de reservas internacionais e intervenções no mercado de câmbio constituem alternativas bastante utilizadas pelas autoridades ao redor do mundo para suavizar o impacto de oscilações cambiais e manter a política monetária dedicada a objetivos domésticos.

Esta pesquisa constitui um esforço inicial em uma investigação mais ampla acerca dos desafios monetários enfrentados por economias emergentes em um contexto de forte integração financeira. Sem dúvida, um aprofundamento analítico no desenvolvimento do modelo trará melhorias substantivas. Adicionalmente, uma dedicação empírica que venha a somar nos vastos, embora ainda inconclusivos, esforços de compreender as inter-relações financeiras e monetárias entre países também parece promissora. 


\section{Referências}

AGENOR, P.-R.; MONTIEL, P. J. Development Macroeconomics. 1996. [S.l.]: Princeton, New Jersey: Princeton University Press, 1996. Citado na página 7.

AIZENMAN, J. The impossible trinity - from the policy trilemma to the policy quadrilemma. Global Journal of Economics, World Scientific, v. 2, n. 01, p. 1350001, 2013. Citado na página 15.

AIZENMAN, J.; CHINN, M. D.; ITO, H. Monetary policy spillovers and the trilemma in the new normal: Periphery country sensitivity to core country conditions. Journal of International Money and Finance, Elsevier, v. 68, p. 298-330, 2016. Citado na página 14.

AIZENMAN, J.; HUTCHISON, M. M. Exchange market pressure and absorption by international reserves: Emerging markets and fear of reserve loss during the 2008-2009 crisis. Journal of International Money and Finance, Elsevier, v. 31, n. 5, p. 1076-1091, 2012. Citado na página 15.

ALFARO, L.; CHARI, A.; KANCZUK, F. The real effects of capital controls: Firm-level evidence from a policy experiment. Journal of International Economics, Elsevier, v. 108, p. 191-210, 2017. Citado na página 15.

AOKI, K.; BENIGNO, G.; KIYOTAKI, N. Monetary and financial policies in emerging markets. Unpublished paper, London School of Economics.[652], 2016. Citado 14 vezes nas páginas 16, 29, 30, 32, $34,36,40,41,42,47,50,64,65$ e 86 .

ARTETA, C.; EICHENGREEN, B.; WYPLOSZ, C. When does capital account liberalization help more than it hurts? [S.1.], 2001. Citado na página 13.

BACCHETTA, P.; CORDONIER, R.; MERROUCHE, O. The rise in foreign currency bonds: The role of capital controls. 2019. Citado na página 15.

BENIGNO, G.; FORNARO, L. Reserve accumulation, growth and financial crises. CEPR Discussion Paper No. DP9224, 2012. Citado na página 15.

BERNANKE, B.; GERLTER, M.; GILCHRIST, S. The Financial Accelerator in a Quantitative Business Cycle Framework, lin J. Taylor and M. Woodford eds, the Handbook of Macroeconomics, 1341 1393. [S.1.]: Amsterdam: North Holland, 1999. Citado na página 35.

BERNANKE, B. S. Federal reserve policy in an international context. IMF Economic Review, Springer, v. 65 , n. 1, p. 1-32, 2017. Citado 2 vezes nas páginas 4 e 18.

BLANCHARD, O. Currency wars, coordination, and capital controls. [S.l.]: National Bureau of Economic Research Cambridge, Mass., USA, 2016. Citado 5 vezes nas páginas 2, 18, 20, 22 e 26.

BLANCHARD, O.; ADLER, G. et al. Can foreign exchange intervention stem exchange rate pressures from global capital flow shocks? [S.l.], 2015. Citado na página 15.

BLANCHARD, O. et al. What have we learned?: Macroeconomic policy after the crisis. [S.1.]: MIT Press, 2014. Citado na página 14.

BOFINGER, P.; MAYER, E.; WOLLMERSHÄUSER, T. Teaching new keynesian open economy macroeconomics at the intermediate level. The Journal of Economic Education, Taylor \& Francis, v. 40, n. 1, p. 80-102, 2009. Citado na página 20.

BOUGHTON, J. M. On the origins of the fleming-mundell model. IMF Staff Papers, Springer, v. 50, n. 1, p. 1-9, 2003. Citado na página 10.

BRAGA, J. d. M. A inflação brasileira na década de 2000 e a importância de políticas não monetárias de controle. [S.l.], 2011. Citado na página 19.

BRUNO, V.; SHIN, H. S. Capital flows and the risk-taking channel of monetary policy. Journal of Monetary Economics, Elsevier, v. 71, p. 119-132, 2015. Citado 2 vezes nas páginas 4 e 46. 
CALVO, G. A. Staggered prices in a utility-maximizing framework. Journal of monetary Economics, North-Holland, v. 12, n. 3, p. 383-398, 1983. Citado na página 31.

CALVO, G. A.; LEIDERMAN, L.; REINHART, C. M. Inflows of capital to developing countries in the 1990s. Journal of economic perspectives, v. 10, n. 2, p. 123-139, 1996. Citado na página 4.

CALVO, G. A.; REINHART, C. M. Fear of floating. The Quarterly Journal of Economics, MIT Press, v. 117 , n. 2, p. 379-408, 2002. Citado na página 8.

CARLIN, W.; SOSKICE, D. Macroeconomics: imperfections, institutions, and policies. OUP Catalogue, Oxford University Press, 2005. Citado na página 22.

CARLIN, W.; SOSKICE, D. Macroeconomics, Institututions, and the Financial System. [S.1.]: Oxford University Press, 2012. Citado na página 19.

CARVALHO, F. A.; CASTRO, M. R.; COSTA, S. Traditional and matter-of-fact financial frictions in a dsge model for brazil: the role of macroprudential instruments and monetary policy. BIS Working Paper, 2014. Citado 3 vezes nas páginas 40, 41 e 42.

CECCHETTI, S.; GRIFFOLI, T. M.; NARITA, M. Does prolonged monetary policy easing increase financial vulnerability? [S.l.]: International Monetary Fund, 2017. Citado na página 4.

CETORELLI, N.; GOLDBERG, L. S. Banking globalization and monetary transmission. The Journal of Finance, Wiley Online Library, v. 67, n. 5, p. 1811-1843, 2012. Citado na página 4.

CHAMON, M.; GARCIA, M. Capital controls in brazil: effective? Journal of International Money and Finance, Elsevier, v. 61, p. 163-187, 2016. Citado na página 15.

COHEN, B. J. The triad and the unholy trinity: lessons for the pacific region. Pacific economic relations in the 1990s: Cooperation or conflict, p. 133-58, 1993. Citado 2 vezes nas páginas 10 e 12.

COHEN, B. J. The triad and the unholy trinity: problems of international monetary cooperation. In: International Political Economy. [S.l.]: Routledge, 2002. p. 255-266. Citado na página 12.

CONTI, B. M. D.; PRATES, D. M.; PLIHON, D. A hierarquia monetária e suas implicações para as taxas de câmbio e de juros e a política econômica dos países periféricos. Economia e Sociedade, SciELO Brasil, v. 23, n. 2, p. 341-372, 2014. Citado na página 7.

DALGIC, H. C. et al. Financial dollarization in emerging markets: An insurance arrangement. [S.l.], 2018. Citado na página 43.

DÁVILA, E.; KORINEK, A. Pecuniary externalities in economies with financial frictions. The Review of Economic Studies, v. 85, n. 1, p. 352-395. Citado na página 16.

DAVIS, J. S.; PRESNO, I. Capital controls and monetary policy autonomy in a small open economy. Journal of Monetary Economics, Elsevier, v. 85, p. 114-130, 2017. Citado 3 vezes nas páginas 29, 64 e 65.

DIXIT, A. K.; STIGLITZ, J. E. Monopolistic competition and optimum product diversity. The American economic review, JSTOR, v. 67, n. 3, p. 297-308, 1977. Citado na página 30.

DORNBUSCH, R. Expectations and exchange rate dynamics. Journal of political Economy, The University of Chicago Press, v. 84, n. 6, p. 1161-1176, 1976. Citado na página 10.

DORNBUSCH, R. Capital controls: an idea whose time is past. Essays in International Finance, Princeton University, p. 20-27, 1998. Citado na página 13.

DORNBUSCH, R.; EDWARDS, S. The macroeconomics of populism. In: The macroeconomics of populism in Latin America. [S.l.]: University of Chicago Press, 1991. p. 7-13. Citado na página 13.

EDWARDS, S. Monetary policy independence under flexible exchange rates: an illusion? The World Economy, Wiley Online Library, v. 38, n. 5, p. 773-787, 2015. Citado na página 14.

EICHENGREEN, B. Globalizing capital: a history of the international monetary system. [S.l.]: Princeton University Press, 1996. Citado 2 vezes nas páginas 9 e 11. 
EICHENGREEN, B.; ESTEVES, R. The trials of the trilemma: International finance 1870-2017. International Finance, 2019. Citado na página 14.

EICHENGREEN, B.; HAUSMANN, R.; PANIZZA, U. Currency mismatches, debt intolerance, and the original sin: Why they are not the same and why it matters. In: Capital controls and capital flows in emerging economies: Policies, practices, and consequences. [S.l.]: University of Chicago Press, 2007. p. 121-170. Citado 2 vezes nas páginas 7 e 8.

FARHI, E.; WERNING, I. Dilemma not trilemma? capital controls and exchange rates with volatile capital flows. IMF Economic Review, Springer, v. 62, n. 4, p. 569-605, 2014. Citado na página 29.

FARHI, E.; WERNING, I. A theory of macroprudential policies in the presence of nominal rigidities. Econometrica, Wiley Online Library, v. 84, n. 5, p. 1645-1704, 2016. Citado 2 vezes nas páginas 16 e 29.

FIGUEIREDO, F.; GOUVEA, S. Repasse cambial para a inflação: o papel da rigidez de preços. $B A N C O$ CENTRAL DO BRASIL (2011). Dez Anos de Metas para Inflação, 2011. Citado na página 19.

FISCHER, S. Capital account liberalization and the role of the i1 $\backslash /$ if. In: $1 m f$ Seminar Asia and the IMF, Hong Kong. [S.l.: s.n.], 1997. v. 19. Citado na página 13.

FISHER, I. The debt-deflation theory of great depressions. Econometrica: Journal of the Econometric Society, JSTOR, p. 337-357, 1933. Citado na página 35.

FLANDERS, M. J. Some problems of stabilization policy under floating exchange rates. In: Trade, Stability, and Macroeconomics. [S.l.]: Elsevier, 1974. p. 111-127. Citado na página 12.

FLANDERS, M. J. International Monetary Economics, 1870-1960: Between the Classical and the New Classical. [S.1.]: Cambridge University Press, 1989. Citado 5 vezes nas páginas 6, 9, 10, 12 e 16.

FLEMING, J. M. Domestic financial policies under fixed and under floating exchange rates. Staff Papers, Springer, v. 9, n. 3, p. 369-380, 1962. Citado na página 10.

FORBES, K.; FRATZSCHER, M.; STRAUB, R. Capital-flow management measures: What are they good for? Journal of International Economics, Elsevier, v. 96, p. S76-S97, 2015. Citado na página 15.

FRANKEL, J. A. International coordination. [S.l.], 2016. Citado 4 vezes nas páginas 1, 6, 14 e 18.

FREDDO, L. A. M. Inflation targeting in Latin America: the role of the exchange rate. Tese (Doutorado) - Universidade de São Paulo, 2019. Citado na página 19.

FRENKEL, J. A.; RAZIN, A. The mundell-fleming model a quarter century later: a unified exposition. Staff Papers, Springer, v. 34, n. 4, p. 567-620, 1987. Citado na página 10.

GABAIX, X.; MAGGIORI, M. International liquidity and exchange rate dynamics. The Quarterly Journal of Economics, MIT Press, v. 130, n. 3, p. 1369-1420, 2015. Citado na página 67.

GALI, J.; MONACELLI, T. Monetary policy and exchange rate volatility in a small open economy. The Review of Economic Studies, Wiley-Blackwell, v. 72, n. 3, p. 707-734, 2005. Citado na página 29.

GAVIN, M.; HAUSMANN, R.; LEIDERMAN, L. Macroeconomics of capital flows to latin america: Experience and policy issues. IDB Working Paper, 1995. Citado na página 4.

GEORGIADIS, G.; MEHL, A. Trilemma, not dilemma: financial globalisation and monetary policy effectiveness. Globalization and Monetary Policy Institute Working Paper, n. 222, 2015. Citado na página 14.

GERTLER, M.; KARADI, P. A model of unconventional monetary policy. Journal of monetary Economics, Elsevier, v. 58, n. 1, p. 17-34, 2011. Citado 2 vezes nas páginas 29 e 32.

GERTLER, M.; KIYOTAKI, N. Banking, liquidity, and bank runs in an infinite horizon economy. American Economic Review, v. 105, n. 7, p. 2011-43, 2015. Citado 4 vezes nas páginas 29, 32,36 e 39.

GERTLER, M.; KIYOTAKI, N.; QUERALTO, A. Financial crises, bank risk exposure and government financial policy. Journal of Monetary Economics, Elsevier, v. 59, p. S17-S34, 2012. Citado na página 35. 
GHOSH, A. R.; OSTRY, J. D.; CHAMON, M. Two targets, two instruments: Monetary and exchange rate policies in emerging market economies. Journal of International Money and Finance, Elsevier, v. 60, p. 172-196, 2016. Citado na página 15.

GIOVANNI, J. d. et al. International spillovers and local credit cycles. 2017. Citado na página 8.

GOLDFAJN, I.; MINELLA, A. Capital flows and controls in Brazil: what have we learned? [S.1.], 2005. Citado na página 13.

GOPINATH, G. et al. Dominant currency paradigm. American Economic Review, v. 110, n. 3, p. 677-719, March 2020. Disponível em: <https://www.aeaweb.org/articles?id=10.1257/aer.20171201>. Citado na página 7 .

GOURINCHAS, P.-O. Monetary policy transmission in emerging markets: An application to chile. Monetary Policy and Global Spillovers: Mechanisms, Effects and Policy Measures, edition, v. 1, p. 279-324, 2018. Citado 3 vezes nas páginas 18, 19 e 21.

GOURINCHAS, P.-O.; REY, H.; SAUZET, M. The international monetary and financial system. Annual Review of Economics, Annual Reviews, v. 11, p. 859-893, 2019. Citado 3 vezes nas páginas 1, 4 e 14.

GOUVEA, S. Price rigidity in brazil: Evidence from cpi micro data. Central Bank of Brazil Working Paper, v. 143, 2007. Citado 2 vezes nas páginas 41 e 50.

GREENWOOD, J.; HERCOWITZ, Z.; HUFFMAN, G. W. Investment, capacity utilization, and the real business cycle. The American Economic Review, JSTOR, p. 402-417, 1988. Citado na página 34.

GUDMUNDSSON, M. Global financial integration and central bank policies in small, open economies. The Singapore Economic Review, World Scientific, v. 62, n. 01, p. 135-146, 2017. Citado na página 18.

HABERLER, G. Prosperity and depression: A theoretical analysis of cyclical movements. [S.l.]: Routledge, 2017. Citado 2 vezes nas páginas 9 e 14 .

HAMADA, K. A strategic analysis of monetary interdependence. Journal of Political Economy, The University of Chicago Press, v. 84, n. 4, Part 1, p. 677-700, 1976. Citado na página 1.

HAN, X.; WEI, S.-J. International transmissions of monetary shocks: Between a trilemma and a dilemma. Journal of International Economics, Elsevier, v. 110, p. 205-219, 2018. Citado na página 14.

HAYEK, F. A. Monetary nationalism and international stability. [S.l.]: London: Longmans, Green, 1937. Citado na página 9.

HELLEINER, E. States and the reemergence of global finance: from Bretton Woods to the 1990s. [S.1.]: Cornell University Press, 1996. Citado na página 11.

HENRY, P. B. Capital account liberalization: Theory, evidence, and speculation. Journal of economic Literature, v. 45, n. 4, p. 887-935, 2007. Citado na página 13.

HICKS, J. R. Mr. keynes and the"classics"; a suggested interpretation. Econometrica: journal of the Econometric Society, JSTOR, p. 147-159, 1937. Citado na página 10.

ILZETZKI, E.; REINHART, C. M.; ROGOFF, K. S. Exchange arrangements entering the 21st century: Which anchor will hold? [S.l.], 2017. Citado na página 8.

JORDÀ, Ò. et al. Global financial cycles and risk premiums. IMF Economic Review, Springer, v. 67, n. 1, p. 109-150, 2019. Citado na página 4.

KEYNES, J. M. Treatise on money. [S.l.]: Harcourt, Brace and Co., 1930. Citado na página 10.

KOSE, M. A. et al. Financial globalization: a reappraisal. IMF Staff papers, Springer, v. 56, n. 1, p. 8-62, 2009. Citado na página 13.

KRUGMAN, P. Currency regimes, capital flows, and crises. IMF Economic Review, Springer, v. 62, n. 4, p. 470-493, 2014. Citado na página 21.

LANDI, V. N. Capital controls, macroprudential measures and monetary policy interactions in an emerging economy. Bank of Italy Temi di Discussione (Working Paper) No, v. 1154, 2017. Citado 4 vezes nas páginas 16, 29, 40 e 42. 
LUCAS, R. E. Why doesn't capital flow from rich to poor countries? The American Economic Review, American Economic Association, v. 80, n. 2, p. 92-96, 1990. ISSN 00028282. Disponível em: $<$ http://www.jstor.org/stable/2006549>. Citado na página 3.

MAGUD, N. E.; REINHART, C. M.; ROGOFF, K. S. Capital controls: myth and reality-a portfolio balance approach. [S.1.], 2011. Citado na página 15.

MEADE, J. E. The theory of international economic policy. [S.l.]: Oxford University Press, 1951. Citado 2 vezes nas páginas 10 e 11.

MENDOZA, E. G. Sudden stops, financial crises, and leverage. American Economic Review, v. 100, n. 5, p. 1941-66, 2010. Citado na página 29.

MENKHOFF, L. Foreign exchange intervention in emerging markets: A survey of empirical studies. The World Economy, Wiley Online Library, v. 36, n. 9, p. 1187-1208, 2013. Citado na página 15.

METZLER, L. A. Wealth, saving, and the rate of interest. Journal of Political Economy, The University of Chicago Press, v. 59, n. 2, p. 93-116, 1951. Citado na página 10.

MIRANDA-AGRIPPINO, S.; REY, H. US monetary policy and the global financial cycle. [S.l.], 2015. Citado 2 vezes nas páginas 4 e 14 .

MORAIS, B. et al. The international bank lending channel of monetary policy rates and qe: Credit supply, reach-for-yield, and real effects. The Journal of Finance, Wiley Online Library, v. 74, n. 1, p. 55-90, 2019. Citado na página 8.

MUNDELL, R. Flexible exchange rates and employment policy. Canadian Journal of Economics and Political Science/Revue canadienne de economiques et science politique, Cambridge University Press, v. 27, n. 4, p. 509-517, 1961. Citado na página 10.

MUNDELL, R. International Economics. [S.l.]: New York, Macmillan, 1968. Citado na página 10.

MUNDELL, R. On the history of the mundell-fleming model. keynote speech. International Monetary Fund Staff Papers Special, v. 47, 2001. Citado na página 10.

MUNDELL, R. A. The monetary dynamics of international adjustment under fixed and flexible exchange rates. The Quarterly Journal of Economics, MIT Press, v. 74, n. 2, p. 227-257, 1960. Citado na página 10 .

MUNDELL, R. A. Capital mobility and stabilization policy under fixed and flexible exchange rates. Canadian Journal of Economics and Political Science/Revue canadienne de economiques et science politique, Cambridge University Press, v. 29, n. 4, p. 475-485, 1963. Citado na página 10.

MUNDELL, R. A. Tariff preferences and the terms of trade. In: . [S.l.: s.n.], 1968. Citado na página 6.

OBSTFELD, M. The global capital market: benefactor or menace? Journal of economic perspectives, v. 12 , n. 4 , p. 9-30, 1998. Citado na página 14.

OBSTFELD, M. Trilemmas and trade-offs: living with financial globalisation. BIS working paper, 2015. Citado na página 14.

OBSTFELD, M.; ROGOFF, K. Exchange rate dynamics redux. Journal of political economy, The University of Chicago Press, v. 103, n. 3, p. 624-660, 1995. Citado 2 vezes nas páginas 13 e 29.

OBSTFELD, M.; SHAMBAUGH, J. C.; TAYLOR, A. M. Financial stability, the trilemma, and international reserves. American Economic Journal: Macroeconomics, v. 2, n. 2, p. 57-94, 2010. Citado na página 15 .

OBSTFELD, M.; TAYLOR, A. M. The great depression as a watershed: international capital mobility over the long run. In: The defining moment: The Great Depression and the American economy in the twentieth century. [S.l.]: University of Chicago Press, 1998. p. 353-402. Citado 4 vezes nas páginas 1, 6, 10 e 12 .

REBUCCI, A.; MA, C. Capital controls: A survey of the new literature. [S.l.], 2019. Citado 2 vezes nas páginas 15 e 62 . 
REINHART, C. M.; ROGOFF, K. S.; SAVASTANO, M. A. Debt intolerance. [S.l.], 2003. Citado na página 8.

REY, H. Dilemma not trilemma: the global financial cycle and monetary policy independence. 2015. Citado 9 vezes nas páginas 3, 7, 14, 18, 22, 29, 37, 42 e 61.

$\mathrm{REY}, \mathrm{H}$. International channels of transmission of monetary policy and the mundellian trilemma. IMF Economic Review, Springer, v. 64, n. 1, p. 6-35, 2016. Citado 2 vezes nas páginas 14 e 18.

RICARDO, D. The high price of bullion. P. Sraffa (1956) ed, v. 3, 1810. Citado na página 9.

RODRIK, D. et al. Who needs capital-account convertibility? Essays in international finance, Princeton University, p. 55-65, 1998. Citado na página 13.

ROGOFF, K. Can international monetary policy cooperation be counterproductive? In: International Economic Policies and their Theoretical Foundations. [S.l.]: Elsevier, 1992. p. 874-892. Citado na página 1.

ROSE, A. K. A review of some of the economic contributions of robert a. mundell, winner of the 1999 nobel memorial prize in economics. The Scandinavian Journal of Economics, JSTOR, v. 102, n. 2, p. 211-222, 2000. Citado na página 11.

ROTEMBERG, J. J. Monopolistic price adjustment and aggregate output. The Review of Economic Studies, Wiley-Blackwell, v. 49, n. 4, p. 517-531, 1982. Citado na página 31.

RUDIGER, D. Open economy macroeconomics. New York: Inc. publishers, 1980. Citado na página 10.

SACHS, J. D. International policy coordination in a dynamic macroeconomic model. [S.l.]: National Bureau of Economic Research Cambridge, Mass., USA, 1983. Citado na página 1.

SCHIOPPA, T. P. Policy cooperation and the ems experience. In: International Economic Policy Coordination. [S.1.]: Cambridge University Press, 1985. p. 331-365. Citado na página 12.

SCHIOPPA, T. P. 12 the european monetary system: A long-term view. The European Monetary System, Cambridge University Press, p. 369, 1988. Citado na página 12.

SCHMITT-GROHÉ, S.; URIBE, M. Optimal simple and implementable monetary and fiscal rules: Expanded version. [S.1.], 2006. Citado na página 85.

SHAPIRO, C.; STIGLITZ, J. E. Equilibrium unemployment as a worker discipline device. The American Economic Review, JSTOR, v. 74, n. 3, p. 433-444, 1984. Citado na página 36.

STIGLITZ, J. E. Capital-market liberalization, globalization, and the imf. Oxford Review of Economic Policy, Oxford University Press, v. 20, n. 1, p. 57-71, 2004. Citado na página 13.

SUMMERS, L. H. International financial crises: causes, prevention, and cures. American Economic Review, v. 90, n. 2, p. 1-16, 2000. Citado na página 13.

TOBIN, J. A proposal for international monetary reform. Eastern economic journal, JSTOR, v. 4, n. 3/4, p. 153-159, 1978. Citado na página 12.

TORNELL, A. Real vs. financial investment can tobin taxes eliminate the irreversibility distortion? Journal of Development Economics, Elsevier, v. 32, n. 2, p. 419-444, 1990. Citado na página 12.

URIBE, M.; SCHMITT-GROHÉ, S. Open economy macroeconomics. [S.l.]: Princeton University Press, 2017. Citado na página 29.

VALle, M. R. d.; TONETO, R. J.; CICOGNA, M. P. V. The Correlation Effect between Commodity Prices and Exchange Rate for Brazilian Firms' Balance Sheets. [S.1.]: Inter-American Development Bank Technical Note; 1168, 2017. Citado na página 8.

WHALE, P. B. The theory of international trade in the absence of an international standard. Economica, JSTOR, v. 3, n. 9, p. 24-38, 1936. Citado na página 9.

ZEEV, N. B. Capital controls as shock absorbers. Journal of International Economics, Elsevier, v. 109, p. 43-67, 2017. Citado 2 vezes nas páginas 15 e 62. 
Apêndices 


\section{APÊNDICE A - Equivalência entre modelo agregado nominal e real}

Demonstraremos aqui que a diferença entre uma autoridade monetária que otimize tendo como instrumento o juros real ou nominal reside apenas em uma reparametrização da economia. Considerando que $\pi^{*}=0$, temos que a equação de determinação da inflação pode ser escrita como:

$$
\pi=\gamma Y+\delta(e-\pi)+v
$$

É direto notar que isso implica em $\pi=+\gamma^{\prime} Y+\delta^{\prime} e+v^{\prime}$ na qual, $X^{\prime}=\frac{X}{1+\delta}$. No caso de $v$ é evidente que a reparametrização implica apenas em um ajuste da variância. O câmbio nominal é descrito pela equação (6).

Substituindo na equação do produto $R$ por $i-\pi$ e $E$ por $e-\pi$ chega-se a:

$$
Y=G-c(i-\pi)-f(e-\pi)+a\left(Y^{*}-Y\right)+b(e-\pi)
$$

Resolvendo para $Y$, sabendo que dado $\pi^{*}=0, i^{*}=R^{*}$ têm-se que:

$$
\begin{aligned}
Y=\omega_{y}^{\prime}\left[G+a G^{*}+\left(\left(1-\delta^{\prime}\right) d(f-b)\right.\right. & -c) i \\
& \left.+\left(\left(1-\delta^{\prime}\right)(d(b-f)+g(b-f))-a c^{*}\right) R^{*}+\left(1-\delta^{\prime}\right)(b-f) \eta\right]
\end{aligned}
$$

Sendo $\omega_{y}^{\prime}=\frac{1}{1+a+\gamma^{\prime}(b-f)}$ e $\eta=\chi-v^{\prime}$, prova-se que a economia as mesmas relações e que, dado os parâmetros, os aspectos fundamentais ainda dependem do tamanho relativo de $b$ e $f$. Como delta $<1$, $\delta^{\prime}<1$ e $\left(1-\delta^{\prime}>0\right.$. Assim, mantidas as hipóteses do modelo,

$$
\begin{aligned}
\Gamma_{i} & \equiv \frac{\partial Y}{\partial R}=\omega_{y}^{\prime}\left(\left(1-\delta^{\prime}\right) d(f-b)-c\right)<0 \\
\Gamma_{i^{*}} & \equiv \frac{\partial Y}{\partial R^{*}}=\omega_{y}^{\prime}\left(\left(1-\delta^{\prime}\right)(d(b-f)+g(b-f))-a c^{*}\right) R^{*}<0 \\
\Gamma_{e} & \equiv \frac{\partial Y}{\partial R}=-d<0
\end{aligned}
$$

A otimização da autoridade monetária implica em:

$$
Y=\frac{\left(\gamma^{\prime} \delta^{\prime} \Gamma_{i}-d \delta^{\prime 2}\right)}{d \gamma^{\prime} \delta^{\prime}-\left(\gamma^{\prime 2}+\lambda\right) \Gamma_{i}} e
$$

Mantida a mesma relação negativa entre produto e neste caso, câmbio nominal. O que implica, dado $\pi$ em uma relação também inversa entre o câmbio real e o produto. Finalmente, fica claro que dada a escolha de parâmetros, é possível que a autoridade monetária opere escolhendo $R$ ou $i$, do ponto de vista do nosso exercício numérico. 


\section{APÊNDICE B - Otimização da Autoridade Monetária do Modelo Agregado}

Partiremos do problema da autoridade monetária:

$$
\left.\underset{\min R}{L}=(\gamma Y+\delta E)^{2}\right)+\lambda\left(Y^{2}\right)
$$

Reorganizando têm-se:

$$
\underset{\operatorname{minR}}{L}=\left(\gamma^{2}+\lambda\right) Y^{2}+2 \delta \gamma Y E+\delta^{2} E^{2}
$$

Substituindo o valor de $Y$ definido em (12), em (11), chega-se a uma expressão para $E$ dependente apenas dos parâmetros, dos choques e das taxas de juros. Tal que, para efeito da necessidade de agora, vale definir

$$
\Gamma_{E} \equiv \frac{\partial E}{\partial R}=-d\left(\omega_{e}+\gamma \omega_{y}\left(\omega_{e} d(f-b)-c\right)\right)<0
$$

A condição de primeira ordem pode ser definida como:

$$
Y\left[\left(\gamma^{2}+\lambda\right) \Gamma_{R}+\gamma \delta \Gamma_{E}\right]+E\left[\gamma \delta \Gamma_{R}+\delta^{2} \Gamma_{E}\right]=0
$$

De tal forma que, no ótimo, deve valer a seguinte relação entre produto e taxa de câmbio,

$$
Y=-\frac{\left[\gamma \delta \Gamma_{R}+\delta^{2} \Gamma_{E}\right]}{\left[\left(\gamma^{2}+\lambda\right) \Gamma_{R}+\gamma \delta \Gamma_{E}\right]} E
$$

como assumimos que $\Gamma_{R}$ e $\Gamma_{E}$ são sempre menores do que zero, esta relação também é negativa. 


\section{APÊNDICE C - Equilíbrio Competitivo}

Detalharemos o processo de otimização dos bancos e também reorganizaremos algumas das equações do equilíbrio encontrado no texto para que fique mais nítida a derivação, no Apêndice D, do Estado Estacionário Não-Estocástico.

Partindo da Equação 51 e da definição de $\phi_{t} \equiv \frac{Q_{t} k_{t}^{b}}{n t}$, temos:

$$
\frac{n_{t+1}}{n_{t}}=\frac{S_{t}+\lambda Q_{t}}{Q_{t}} \phi_{t}-\Gamma \frac{\epsilon_{t+1}}{\epsilon_{t}} x_{t} \phi_{t}-R_{t+1} \frac{d_{t}}{n_{t}}
$$

Usando a restrição de balanço patrimonial dos bancos, Equação 45

$$
\frac{n_{t+1}}{n_{t}}=\frac{S_{t}+\lambda Q_{t}}{Q_{t}} \phi_{t}-\Gamma \frac{\epsilon_{t+1}}{\epsilon_{t}} x_{t} \phi_{t}-R_{t+1}\left[\left(1+\tau_{n}^{K}\right) \phi_{t}+\kappa^{b} x_{t} \phi_{t}-\left(1+\tau_{t}^{N}\right)-\left(1-\tau_{t}^{d}\right) x_{t} \phi_{t}\right]
$$

Chegamos assim à:

$$
\frac{n_{t+1}}{n_{t}}=\left[\frac{S_{t}+\lambda Q_{t}}{Q_{t}}-\left(1+\tau_{t}^{K}\right) R_{t+1}\right] \phi_{t}+\left[\left(1-\tau_{t}^{d}\right) R_{t+1}-\Gamma \frac{\epsilon_{t+1}}{\epsilon_{t}}\right] x_{t} \phi_{t}+\left(1+\tau_{t}^{N}-\kappa^{b} x_{t} \phi_{t}\right) R_{t+1}
$$

e ao problema de maximização dos bancos descrito no texto.

$$
\begin{aligned}
& \psi_{t}=\underset{\phi_{t}, x_{t}}{\operatorname{Max}}\left[\mu_{t} \phi_{t}+\mu_{t}^{*} \phi_{t} x_{t}+\left(1+\tau_{t}^{N}-\kappa^{b} x_{t} \phi_{t}\right) v_{t}\right] \\
& \quad \text { s.a } \\
& \psi_{t} \geq \Theta\left(x_{t}\right) \phi_{t}=\theta_{0} \exp \left(\theta x_{t}\right) \phi_{t}
\end{aligned}
$$

Sabemos que a função objetivo é estritamente crescente em $\phi_{t}$ e $x_{t}$ para $\mu_{t}, \mu_{t}^{*}>\kappa^{b} v_{t}$, o que é assegurado pela escolha dos parâmetros. Também a compatibilidade de incentivos, da forma como foi apresentada, é estritamente crescente de tal forma que a restrição só será ativa caso o benefício marginal de operar honestamente for menor do que o ganho marginal do desvio. Isto é, quando $d\left(\Theta\left(x_{t}\right)\right) \phi_{t}>d\left(\psi_{t}\right)$. 
Figura 24 - Problema do banco em relação à $x_{t}$

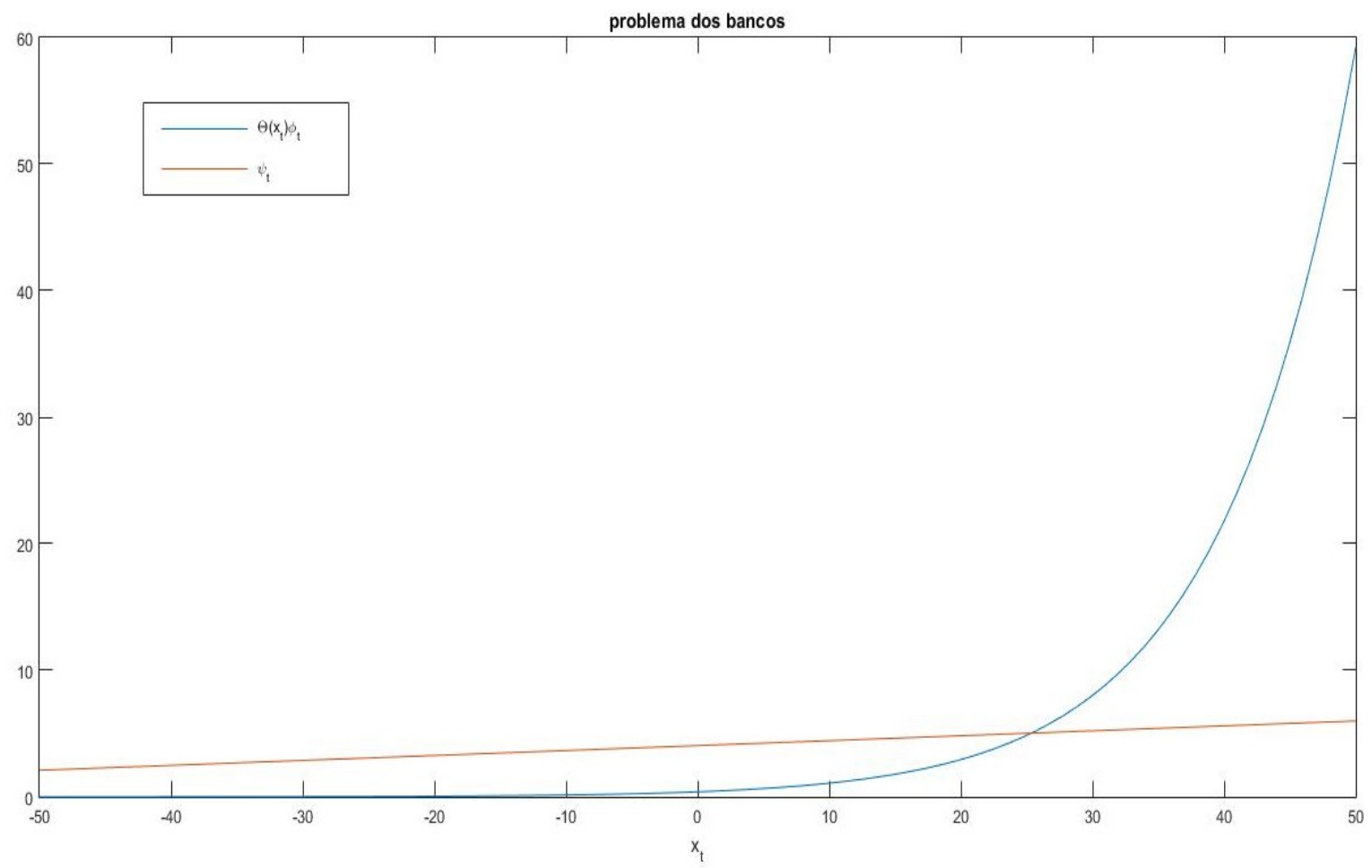

A Figura 24 mostra, para uma dada configuração de parâmetros, a função objetivo $\psi_{t}$ em vermelho e a proporção de ativos desviados em verde. Vemos que, para o caso de $x_{t}$ - e o caso de $\phi_{t}$ é análogo - que até $x_{t}=25$ aproximadamente, é possível para o banco elevar seu valor presente esperado via aumento de endividamento externo satisfazendo a restrição. Isto é, faz sentido que o banco opere neste região, pois, caso contrário, seria possível aumentar $\psi_{t}$ elevando $\phi_{t}$ e $x_{t}$ sem que isso implicasse uma incompatibilidade da restrição Ao mesmo tempo, que caso passe do ponto de igualdade, ele deixa de operar como banco, ao ser forçado a sair do mercado após o desvio. Logo, ele opera na igualdade da restrição.

Dessa forma, o lagrangiano do problema do banco e as condições de primeira ordem do problema em relação à proporção de endividamento externo e a alavancagem são:

$$
\begin{gathered}
L=\left(1+\lambda_{t}\right)\left[\mu_{t} \phi_{t}+\mu_{t}^{*} \phi_{t} x_{t}+\left(1+\tau_{t}^{N}-\kappa^{b} x_{t} \phi_{t}\right) v_{t}\right]-\lambda\left(\Theta\left(x_{t}\right) \phi_{t}\right) \\
x_{t}:\left(1+\lambda_{t}\right)\left(\mu_{t}^{*}-\kappa^{b} v_{t}\right)=\lambda\left(\theta \Theta\left(x_{t}\right)\right) \\
\phi_{t}:\left(1+\lambda_{t}\right)\left(\mu_{t}+\mu_{t}^{*} x_{t}-\kappa^{b} x_{t}\right)=\lambda \Theta\left(x_{t}\right)
\end{gathered}
$$

Combinando as duas condições chegamos na Equação 58:

$$
x_{t}=\frac{\frac{\mu_{t}}{v_{t}}}{\kappa^{b}-\frac{\mu_{t}^{*}}{v_{t}}}+\frac{1}{\theta}
$$

Nitidamente, o endividamento externo dos bancos é função crescente de $\frac{\mu_{t}}{v_{t}}$ e $\frac{\mu_{t}^{*}}{v_{t}}$. Usando o fato de que a compatibilidade de incentivos vale com igualdade no ótimo, chega-se às equações Equação 56 e ??. Mostraremos que também $\phi_{t}$ é crescente em $\frac{\mu_{t}}{v_{t}}$ e $\frac{\mu_{t}^{*}}{v_{t}}$. Seja $\Psi^{\prime}\left(x_{t}\right)$ o denominador Equação 56 após dividirmos numerador e denominador por $v_{t}$ e utilizando as condições de primeira ordem do problema acima, têm-se: 


$$
\begin{aligned}
\Psi^{\prime}\left(x_{t}\right) & =\frac{\Theta\left(x_{t}\right)}{v_{t}}+\kappa^{b} x_{t}-\left(\frac{\mu_{t}}{v_{t}}+\frac{\mu_{t}^{*}}{v_{t}}\right) \\
\frac{\partial \Psi^{\prime}\left(x_{t}\right)}{\partial \frac{\mu_{t}}{v_{t}}} & =\frac{1}{\kappa^{b}-\frac{\mu_{t}^{*}}{v_{t}}}\left(\frac{1}{v_{t}} \Theta\left(x_{t}\right)-\frac{\mu_{t}^{*}}{v_{t}}+\kappa^{b}\right)-1<0 \\
\frac{\partial \Psi^{\prime}\left(x_{t}\right)}{\partial \frac{\mu_{t}^{*}}{v_{t}}} & =\frac{\frac{\mu_{t}}{v_{t}}}{\left(\kappa^{b}-\frac{\mu_{t}^{*}}{v_{t}}\right)^{2}}\left(-\frac{1}{v_{t}} \Theta\left(x_{t}\right)+\frac{\mu_{t}^{*}}{v_{t}}-\kappa^{b}\right)-x_{t}<0
\end{aligned}
$$

Mostrando que de fato, o endividamento externo e a alavancagem dos bancos são funções crescentes de $\frac{\mu_{t}}{v_{t}}$ e $\frac{\mu_{t}^{*}}{v_{t}}$ e portanto, funções decrescentes de $\tau_{t}^{K}, \tau_{t}^{d}$.

Seguindo na organização do equilíbrio competitivo, usando o fato que $\Phi\left(\frac{I_{t}}{I}\right)=\frac{\kappa_{I}}{2} \hat{I}_{t}^{2}$, a Equação 40 pode ser escrita como:

$$
\frac{1}{\kappa_{I}}\left(Q_{t}-1\right)=\frac{1}{2} \hat{I}_{t}^{2}+\hat{I}_{t}\left(\hat{I}_{t}+1\right)
$$

Resolvendo a equação de segundo grau para $\hat{I}_{t}$, chega-se que a raiz com sentido econômico, ou seja, na qual uma elevação do preço do capital aumenta o investimento, é tal que:

$$
\hat{I}_{t}=\hat{I}_{t}\left(Q_{t}\right)=\frac{1}{3}\left[-1+\sqrt{1+\frac{6}{\kappa_{I}}\left(Q_{t}-1\right)}\right]
$$

Reescrevendo a acumulação de capital para $\Phi\left(\frac{I_{t}}{I}\right)=\frac{\kappa_{I}}{2} \hat{I}_{t}^{2}$ :

$$
K_{t}=\lambda K_{t-1}+\left[\hat{I}_{t}\left(Q_{t}\right)+1\right] I
$$

O equilíbrio do mercado de bens pode então ser definido como:

$$
\begin{array}{r}
{\left[1-\frac{\kappa}{2}\left(\pi_{t}-1\right)^{2}\right] Y_{t}-\chi^{h}\left(K_{t}^{h}, K_{t}\right)-\chi^{b}\left(\epsilon_{t} D_{t}^{*}, Q_{t} K_{t}^{b}\right) \quad} \\
\quad=C_{t}+\left[1+\frac{\kappa_{I}}{2} \hat{I}_{t}^{2}\right]\left[\hat{I}_{t}\left(Q_{t}\right)+1\right] I+\epsilon_{t}^{\varphi} Y_{t}^{*}
\end{array}
$$

Usando as Equações (32), (33), (34), (37) temos:

$$
\begin{gathered}
M_{t}=\frac{\alpha_{m}}{\alpha_{k}} \frac{S_{t} K_{t-1}}{\epsilon_{t}} \\
L_{t}^{1+\zeta}=\frac{1-\alpha_{k}-\alpha_{m}}{\alpha_{k}} \frac{S_{t} K_{t-1}}{\zeta_{0}} \\
S_{t}=\left\{\left(\frac{\epsilon_{t m}^{\alpha} Y_{t}}{Z_{t}}\right)^{1+\zeta}\left(\frac{\alpha_{k}}{K_{t-1}}\right)^{1+\zeta\left(\alpha_{k}+\alpha_{m}\right)}\left[\left(1-\alpha_{k}-\alpha_{m}\right)^{\zeta} \zeta_{0}\right]^{1-\alpha_{k}-\alpha_{m}}\right\}^{\frac{1}{1-\alpha_{k}+\zeta \alpha_{m}}}
\end{gathered}
$$

Finalmente, o equilíbrio do balanço de pagamentos pode ser reescrito como:

$$
D_{t}^{*}=R_{t} D_{t-1}^{*}+\epsilon_{t} M_{t}-\epsilon_{t}^{\varphi-1} Y_{t}^{*}
$$




\section{APÊNDICE D - Estado Estacionário Não-Estocástico}

Da Equação 40 sabemos que:

$$
Q=1
$$

De sua definição deriva-se que $\Lambda=\beta$, junto com (39) chegamos à:

$$
R=\frac{1}{\beta}
$$

Da definição do Estado Estacionário (E.E) não inflacionário, que é verificado na rega de taylor, temos que $\pi=1$.

Defina:

$$
\begin{aligned}
s p & =\beta(S+\lambda)-1 \\
s p^{*} & =1-\beta \Gamma
\end{aligned}
$$

Em que $\frac{s p}{\beta}$ e $\frac{s p^{*}}{\beta}$ são respectivamente o spread de E.E que os bancos tem em relação aos depósitos bancários e a vantagem do financiamento externo em relação ao doméstico. Usando (38), (52), (53) e (54) chega-se que, em equilíbrio

$$
\begin{aligned}
\frac{K^{h}}{K} & =\frac{s p}{\kappa^{h}} \\
\frac{\mu}{v} & =s p-\tau^{K} \\
\frac{\mu^{*}}{v} & =s p^{*}-\tau^{d}
\end{aligned}
$$

Substituindo estas relações na Equação 58, chega-se a:

$$
x=\frac{s p-\tau^{k}}{\kappa^{b}-\left(s p^{*}-\tau^{d}\right)}+\frac{1}{\theta}
$$

Ao redor de $\tau^{N}=\tau^{K}=\tau^{d}=0$, podemos escrever

$$
G=\frac{n_{t+1}}{n_{t}}=\frac{1}{\beta}[p \phi+1]
$$

em que $p=\left[s p+s p^{*} x-\kappa^{b} x\right]$. Substituindo G na equação do patrimônio líquido agregado dos bancos, (65) encontramos que 


$$
\begin{aligned}
& \beta=\beta \sigma G+\xi(1+s p) \phi \frac{1}{1-\frac{K^{h}}{K}} \\
& \phi=\frac{\beta-\sigma}{\sigma p+\xi \frac{1+s p}{1-\frac{s p}{\kappa h}}}
\end{aligned}
$$

e podemos reescrever a equação (51) tal que:

$$
\begin{aligned}
& \psi=\beta(1-\sigma+\sigma \psi) G \\
& \psi=\frac{(1-\sigma)(p \phi+1)}{(1-\sigma-\sigma p \phi)}
\end{aligned}
$$

usando Equação 103, p é definido apenas por variáveis exógenas tal que $p=\frac{s p^{*}-\kappa_{b}}{\theta}$. A equação (57) pode ser reescrita tal que:

$$
\frac{(1-\sigma)(p \phi+1)}{(1-\sigma-\sigma p \phi)}=\Theta(x) \phi
$$

considerando que $\xi \rightarrow 0$

$$
\begin{aligned}
\phi & =\frac{\beta-\sigma}{\sigma p} \\
\psi=\frac{(1-\sigma) \beta}{(1-\beta) \sigma} & =\theta_{0} \exp \left(1+\frac{\theta s p}{\kappa_{b}-s p^{*}}\right) \\
A & \equiv \frac{(1-\sigma) \beta}{(1-\beta) \sigma} \\
\ln (A) & =\ln \left(\theta_{0}\right)+1+\frac{\theta s p}{\kappa_{b}-s p^{*}} \\
\alpha_{s} & \equiv \ln (A)-\ln \left(\theta_{0}\right)
\end{aligned}
$$

sendo assim,

$$
s p=\frac{\left(s^{*}-\kappa_{b}\right)}{\theta}\left(1-\alpha_{s}\right)
$$

De tal forma que é possível escrever, no estado estacionário ao redor de $\tau^{N}=\tau^{K}=\tau^{d}=\xi=0$, todas as variáveis bancárias como funções apenas de parâmetros e variáveis exógenas.

Tendo $s p$ como funções dos parâmetros, determinam-se

$$
\begin{aligned}
S & =\frac{1}{\beta}(1+s)-\lambda \\
\frac{K^{h}}{K} & =\frac{s p}{\kappa^{h}}
\end{aligned}
$$

Usando (29), (31), (32), (33) e (34), temos que 


$$
\begin{aligned}
m c & =1-\frac{1}{\eta}=\frac{S K}{\alpha_{k} Y} \\
\frac{K}{Y} & =\left(1-\frac{1}{\eta}\right) \frac{\alpha_{k}}{S}
\end{aligned}
$$

De (103) com (29), (37) podemos reescrever mc como

$$
\left(1-\frac{1}{\eta}\right)^{1-\alpha_{k}-\zeta_{0} \alpha_{m}}=\left[\frac{\epsilon^{\alpha_{m}}}{Z}\left(\frac{\alpha_{k} Y}{K}\right)^{\alpha_{k}}\right]^{1+\zeta}\left[\left(1-\alpha_{k}-\alpha_{m}\right)^{\zeta} Y^{\zeta} \zeta_{0}\right]^{1-\alpha_{k}-\alpha_{m}}
$$

De onde se tira que

$$
Y=\frac{1}{\left.1-\alpha_{k}-\alpha_{m}\right) \zeta_{0}^{\frac{1}{\zeta}}}\left[\left(1-\frac{1}{\eta}\right)^{1-\alpha_{k}-\zeta_{0} \alpha_{m}}\left(\frac{S}{\epsilon^{\alpha_{m}} S^{\alpha_{k}}}\right)^{1+\zeta}\right]^{\frac{1}{\zeta\left(1-\alpha_{k}-\alpha_{m}\right)}}
$$

A acumulação de capital no estado estacionário, portanto, pode ser escrita como

$$
\begin{aligned}
I & =(1-\lambda) K \\
& =(1-\lambda)\left(1-\frac{1}{\eta}\right) \frac{\alpha_{k}}{S} Y
\end{aligned}
$$

As transações correntes podem ser definidas por meio de

$$
\begin{aligned}
\frac{\epsilon^{\varphi} Y^{*}}{Y} & =\frac{\epsilon M}{Y}+\left(R^{*}-1\right) \frac{\epsilon D^{*}}{Y} \\
& =\alpha_{m}\left(1-\frac{1}{\eta}\right)+\left(R^{*}-1\right) x\left(1-\frac{s p}{\kappa^{h}}\right) \frac{K}{Y}
\end{aligned}
$$

Finalmente

$$
\frac{C}{Y}=1-(1-\lambda) \frac{K}{Y}-\frac{\epsilon^{\varphi} Y^{*}}{Y}-\frac{s p^{2}}{2 \kappa_{h}} \frac{K}{Y}-\kappa_{b} x\left(1-\frac{s p}{\kappa^{h}}\right) \frac{K}{Y}
$$




\section{APÊNDICE E - Análise de Bem-Estar}

A análise feita até aqui, indica de que maneira políticas ou especificações alternativas do modelo base são mais ou menos efetivas na acomodação de um choque externo. Dizem pouco, entretanto, sobre o efeito destas políticas para o bem-estar dos consumidores. Por um lado, a análise anterior é suficiente para que se discuta o objetivo central desta dissertação quanto ao problema da autonomia de política monetária em economias periféricas. Entretanto, não permite que se façam extrapolações sobre a qualidade destas políticas à preferência dos agentes. Para lidar com esta ambição, a literatura propõe diferentes formas de medida de bem-estar. Dentre as quais, escolhemos uma que nos parecia melhor adaptável ao modelo.

Partiremos, seguindo Schmitt-Grohé e Uribe (2006), da otimização numérica a partir da especificação de regras de políticas. Em particular, utilizaremos aqui a maximização, condicional a estarmos no estado estacionário determinístico, da seguinte função de bem-estar:

$$
W_{t}=\mathbb{E}_{t} \sum_{j=0}^{\infty} \beta^{j}\left[U\left(c_{t+j}, L_{t+j}\right)\right]
$$

que na forma recursiva se torna:

$$
W_{t}=U\left(c_{t}, L_{t}\right)+\beta \mathbb{E}_{t}\left(W_{t+1}\right)
$$

Dada a natureza das políticas adotadas, é importante que se faça a aproximação do modelo em $2^{\text {a }}$ Ordem, uma vez que que o valor esperado das variáveis na primeira ordem é igual ao seu valor de estado estacionário determinístico e que não é afetado pela política. Dito de outra forma, para captar o efeito da trajetória da economia entre um choque e seu retorno ao estado estacionário e a relevância da aversão ao risco dos agentes, devemos levar em conta o impacto da política sobre a variância do modelo, o que é captado pela segunda ordem. Por ser comum a todas as especificações do choque, podemos definir o estado estacionário determinístico como ponto inicial da economia e garantir as mesmas condições inicias para as análises de política.

Uma alternativa à análise do bem-estar condicional é o bem-estar não condicional, em que se maximiza a média ergódica do modelo. Ou seja, otimiza-se a expectativa não condicional da utilidade considerando a convergência da economia para o estado estacionário estocástico, no qual, embora os choques nunca de fato ocorram, os agentes fazem suas escolhas antecipando racionalmente a chegada dos choques. Da forma como entendemos, diante do fato de que diferentes políticas estão associadas com diferentes estados estacionários estocásticos, a maximização não condicional, ao não estabelecer às condições iniciais, deixa de considerar efeitos da transição para o estado estacionário estocástico.

Construímos um algorítimo de seleção dos parâmetro das políticas alternativas a partir do bemestar condicional ensejado por elas. Desta forma determinamos os valores de $\omega_{\tau^{K}}$ e $\omega_{\tau^{d}}$ utilizados no Capítulo 3. Há entretanto uma contradição entre os resultados encontrados para o equivalente consumo associado com estas políticas, as referências da literatura e o sentido econômico. Tanto na análise do bem-estar condicional, como também em testes de robustez que fizemos utilizando o bem-estar não condicional, as políticas aqui adotadas aumentam desproporcionalmente o bem-estar, ao ponto de não fazer sentido falar em equivalente consumo. 
O motivo principal é o prêmio de risco. Ele amplia de maneira extravagante a variância do modelo que é decorrência de variações da taxa de juros externa. O que pode ser analisado de duas formas: a primeira é uma dúvida de sua aplicabilidade ou precisão; de outro modo, entendendo que ele deriva de hipóteses bastante simples e baseadas em larga evidência empírica na literatura, pode-se reforçar a importância desta inclusão como sendo algo central e constitutivo para a análise. Mesmo porque, ao considerar o modelo sem a determinação específica do prêmio risco, ainda assim a ampliação de bem-estar associado a adoção de controles de capitais é bastante elevada.

$\mathrm{Na}$ especificação do bem-estar condicional, para o modelo completo temos que a formação de preços de maneira mais rígida equivale a um aumento de consumo de $12 \%$ em relação ao modelo base. A diminuição de $\omega_{\pi}$ para 1.2, significa um ganho de $80 \%$ no consumo enquanto ponderar os desvios do produto por $\omega_{y}=0.5$, seria como aumentar em $150 \%$ o consumo. Migrar do modelo com cilco financeiro global, para um sem este elemento, equivale numa ampliação de consumo de $95 \%$. Finalmente, a adoção conjunta dos controle de capital tem equivalente consumo ao redor de $120 \%$ no caso em que há a modelagem do prêmio de risco dependente dos fatores globais e de $40 \%$ em relação ao modelo sem esta especificação. Para se ter uma base de comparação, o equivalente consumo encontrado por Aoki, Benigno e Kiyotaki (2016) na política adotada por eles chega, ao valor máximo, de $0.8 \%$. Se há sentido ao menos ordinal nestes números, percebemos que do ponto de vista das escolhas políticas, a mais desejável do ponto de vista do bem-estar seria que a autoridade monetária ponderasse positivamente os desvios do produto em relação ao seu valor de equilíbrio na definição da taxa de juros, seguido logo atrás pela adoção de medidas financeiras. 


\section{APÊNDICE F - Choques Domésticos}

A Figura 25 apresenta, para um determinado conjunto de variáveis, os impactos de um choque de $1 \%$ na produtividade. Como esperado, o crescimento do produto e a maior demanda por fatores, elevam a renda, o consumo, o investimento e o preço das ações. Dada a natureza de oferta do choque, não há uma pressão inflacionária, ao contrário, uma inicial deflação pressiona por uma redução de juros por parte da autoridade monetária,o que deprecia o câmbio, melhora as exportações líquidas e incentiva ainda mais o investimento, perpetuando o ciclo expansionista. A ampliação da renda doméstica diminui a necessidade do financiamento externo e que em conjunto com uma melhora das exportações líquidas diminui a dívida externa permanentemente.

Figura 25 - Modelo Base: Choque de $+1 \%$ na produtividade
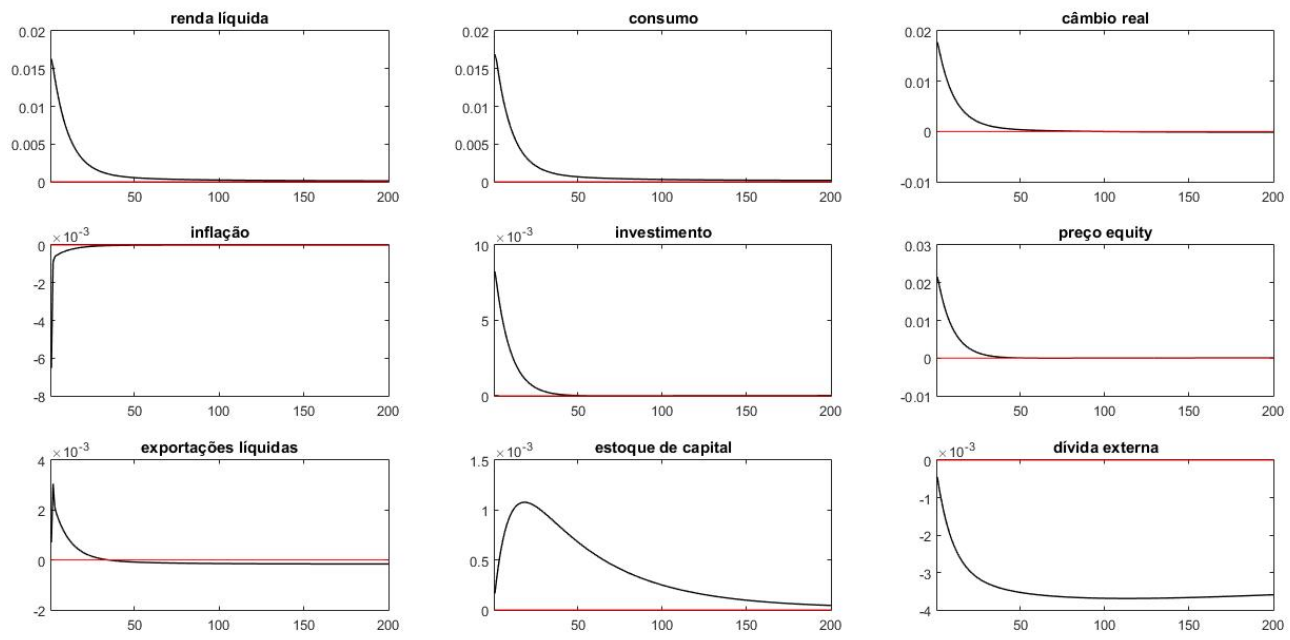

Já a Figura 26 apresenta, para o mesmo conjunto de variáveis, os impactos de um choque de $1 \%$ na taxa de juros nominal anual. A intuição dos resultados é direta. A elevação dos juros dá origem a um choque contracionista na economia doméstica, a queda do investimento e do estoque de capital ampliam a recessão e tornam perenes a diminuição da renda e do consumo. s 
Figura 26 - Modelo Base: Choque de $+1 \%$ no juro nominal doméstico (anual)
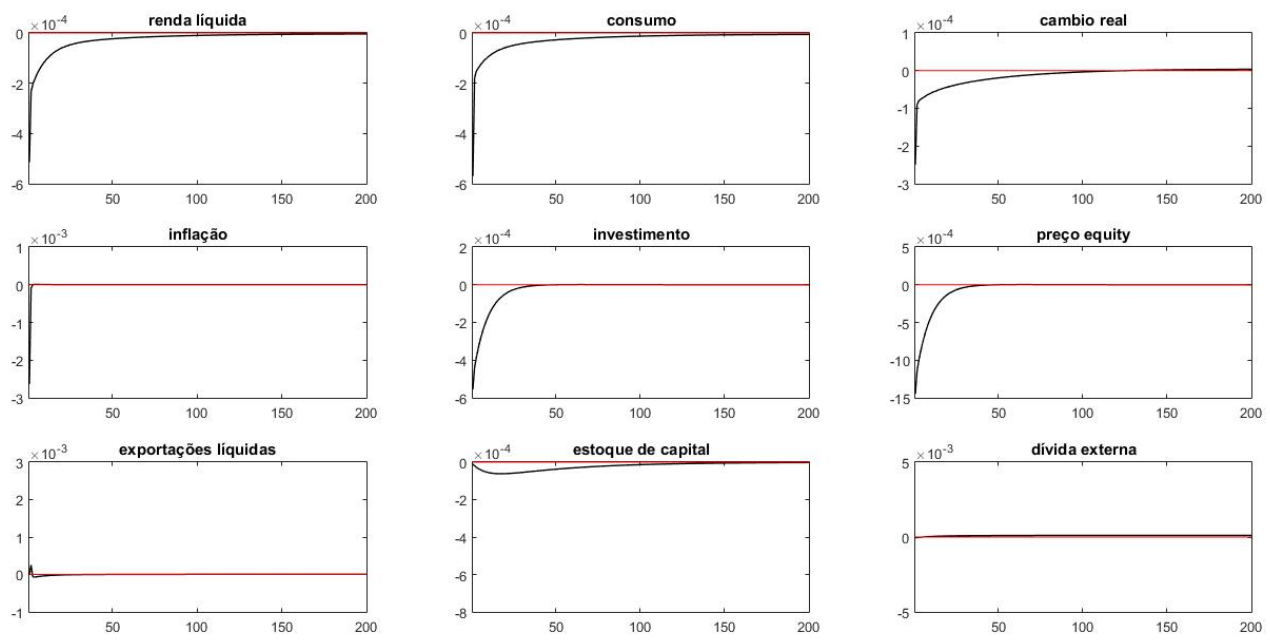